\title{
THE NEW ZEALAND PRODUCTIVITY PUZZLE: A PARADOX OR AN ISSUE OF 'FIRM GOVERNANCE'
}

\author{
BY \\ SODANY TONG
}

\begin{abstract}
A thesis
submitted to the Victoria University of Wellington

in fulfillment of the requirements for the degree of

Master of Commerce

in Economics
\end{abstract}

Victoria University of Wellington

2015 


\section{Abstract}

New Zealand's productivity under-performance, despite its good quality institutions, has remained a puzzling phenomenon. This topic has generated spirited debates among academia and public policy experts seeking to provide an answer to this age-old paradox. Solving 'The New Zealand Productivity Puzzle' is not a straightforward proposition. Previous studies in this area attempted to pin down the main determinants behind the extent to which New Zealand's actual GDP per capita growth has undershot its predicted rates based on policy settings (Barnes et al., 2013). The recent New Zealand Productivity Commission (2014a) report shows the three key determinants accounting for such a gap are New Zealand's weak international connections, low innovation and low managerial quality. This paper seeks to go further than merely highlighting the determinants (symptoms) of poor productivity performance in New Zealand, to the cause(s) of the problem by asking 'why' these key determinants (symptoms) of poor productivity performance occur. The analytical process of piecing together key results and findings (from available data, literature, and empirical studies) enables one to build a richer picture of New Zealand's relatively poor productivity performance, to better understand the mechanism behind this puzzling phenomenon. The findings unraveled in this paper verify that this phenomenon is not paradoxical but simply an issue of firm/corporate governance. The sort of issues uncovered here is neither one of poor corporate governance in a conventional manner or an issue of managerial competency alone. Rather problems arise largely as a consequence of inappropriate incentives unintentionally generated by a certain ownership structure. This paper discusses how high ownership concentration associated with lower firm performance in New Zealand negatively affects managerial effectiveness by exacerbating the agency costs associated with managerial entrenchment. The paper shows that together New Zealand's relatively lower managerial competency and managerial effectiveness associated with lower firm performance, can account for New Zealand's lack of international connections, low innovation and low managerial quality, and thus potentially explain 'The New Zealand Productivity Puzzle'.

Keywords: New Zealand productivity puzzle, firm governance, firm performance, managerial competency, managerial effectiveness, international connections, innovations, managerial quality

JEL Classification Codes: B15, B25, B52, D03, D74, E03, L1, L2, O1, O3, O4, O5. 


\section{Acknowledgements}

I wish to acknowledge and thank the following special people for their contributions to the formation of this thesis.

First and foremost, I would like to thanks my supervisor, Prof. Morris Altman, for all his support, guidance and patience throughout the course of this research. His words of encouragement and wisdom have made the journey of my Master a great one.

This thesis, however, is simply a step on a high way. Problem definition is where it is. Which is the objective of this 'Master Thesis'. Through this research process I also have more research questions to ask and my hypothesis needs further testing and investigation. All of these will be cover in my $\mathrm{PhD}$ programme. Prof. Morris Altman will continue to supervise me on this project and I am very thankful for that.

I am forever indebted to my parents, my grandparents, aunty, brother and the rest of my family for their support, prayers and patience while I carried out this research. 


\section{Table of Contents}

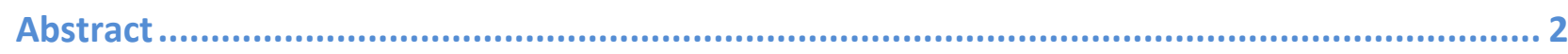

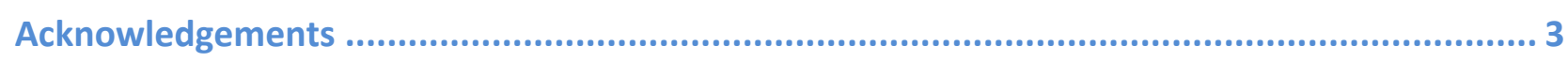

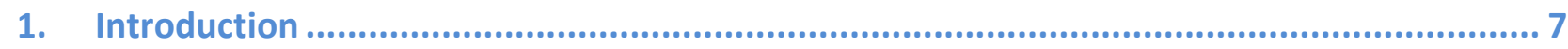

2. The New Zealand Productivity Puzzle Overview...................................................... 8

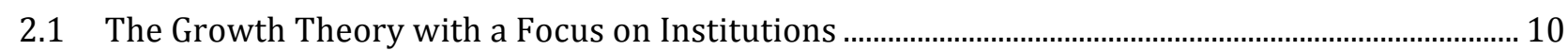

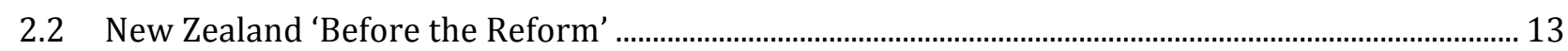

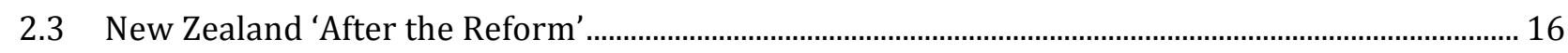

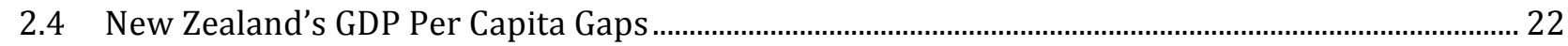

2.5 New Zealand's Productivity Under-Performance .................................................................................. 22

2.6 New Zealand's Productivity Under-Performance despite Its Strong Institutions ........................... 34

3. New Zealand's Relative Productivity Under-Performance - The Debates...................... 36

3.1 NZ's Productivity Under-Performance: An Issue of Relative Geographic Isolation ........................ 37

3.2 NZ's Productivity Under-Performance: An Issue of Relative High Interest Rates ........................... 38

3.3 NZ's Productivity Under-Performance: An Issue of Firm/Corporate Governance........................... 46

4. (A) Managerial Competency, Firm Performance and Productivity.............................. 51

4.1 Assessing Managerial Competency Using Managerial Practice Score (MPS).................................... 52

4.1.1 Managerial Practice Score (MPS) - Productivity Relation ................................................................ 53

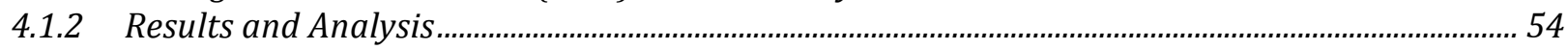

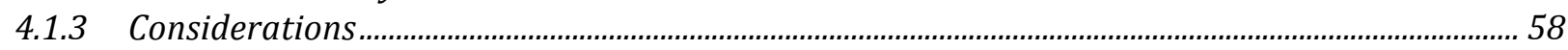

5. (B) Managerial Effectiveness, Firm Performance and Productivity ............................... 59

5.1 Assessing Managerial Effectiveness Using a Meta-Analysis ................................................................. 65

5.1.1 Meta-Analysis: Insider Ownership-Tobin's Q Relation.................................................................. 69

5.1.2 Search and Selection of Studies for Analysis.................................................................................... 70

5.1.3 Results and Analysis - The United States Studies ................................................................................ 75

5.1.4 Results and Analysis - The New Zealand Studies .......................................................................... 81

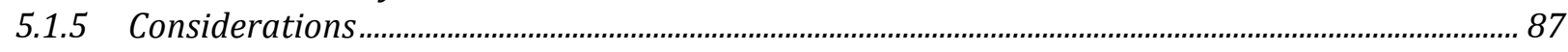

6. New Zealand's Low Firm Performance and Productivity .......................................... 88

6.1 Low Firm Performance and Weak International Connections ........................................................... 90

6.2 Low Firm Performance and Low Innovation ...................................................................................... 94

6.3 Low Firm Performance and Low Managerial Competency.................................................................101

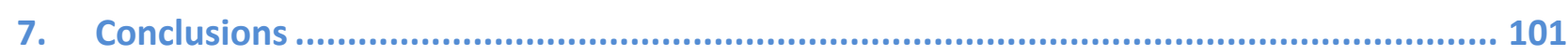

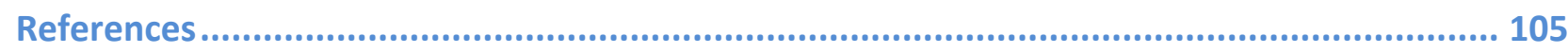

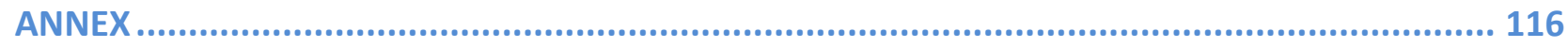

1. OECD Member Countries .......................................................................................................................

2. New Zealand's Firm Size, Productivity and Pay ..................................................................................116

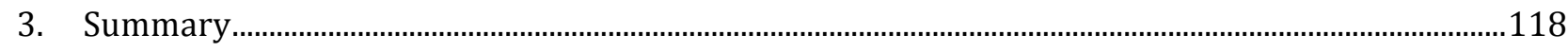




\section{List of Tables}

Table 1: Sources of Economic Growth 1970-2000 (in Average Annual Percentage Change) ..................28

Table 2: NZ's GDP - Composition, by Sector (as \% of GDP) ................................................................40

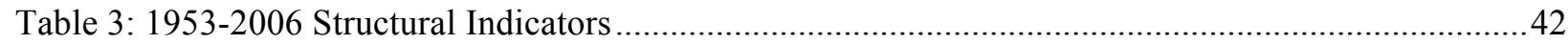

Table 4: Average Management Practice Score (MPS) Outcomes from Three Studies...............................54

Table 5: Managerial Performance and Productivity Relation - Using Spearman .....................................56

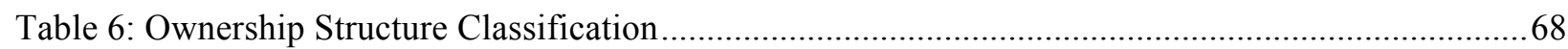

Table 7: Selected Studies on Firm Ownership Structure and Firm Performance........................................72

\section{List of Figures}

Figure 1: The Gap Predicted from Various Structural Policies vs. Observed Gap in GDP Per Capita

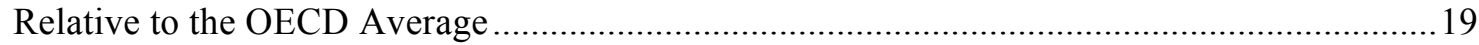

Figure 2: GDP Per Capita - New Zealand vs. Other Selected OECD Countries .........................................20

Figure 3: NZ's Gaps in Per Capita GDP and Productivity Persists: Gap to the Upper Half of OECD

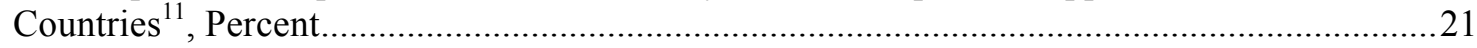

Figure 4: Per Capita GDP Percentage Gap Relative to New Zealand........................................................22

Figure 5: The Range of MFP Outcomes Across M, SM, ML and SML Approach, 1970-2003 ................25

Figure 6: SML - Efficiency Change and Technical Change, 1970-2003 …..............................................26

Figure 7: New Zealand's Productivity in the Measured Sector: Contribution to Output Growth from

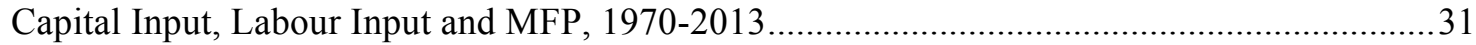

Figure 8: New Zealand's Labour Productivity Decomposition - Contribution from Capital Deepening

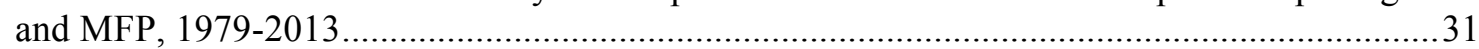

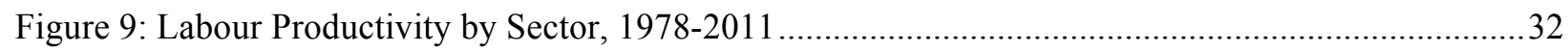

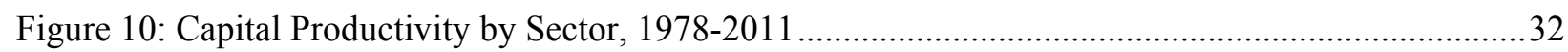

Figure 11: Multifactor Productivity by Sector, 1978-2011 .................................................................33

Figure 12: NZ's International Ranking Based on Real GDP Per Capita, 1890-2010 ................................35

Figure 13: NZ's Productivity (Output per worker in 1990 \$GK), 1896-1960 ..........................................37

Figure 14: NZ's Management Practice Score (MPS) Relative to Our OECD Counterparts .......................55

Figure 15: GDP Per Hour Worked Rank vs. MPS Rank for 11 OECD Countries.....................................57

Figure 16: Tobin's Q as a Function of Insider Ownership (The US Studies) ...........................................76

Figure 17: Tobin's Q as a Function of Insider Ownership (The NZ Study) .............................................. 82

\section{List of Boxes}

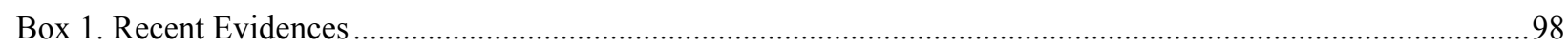

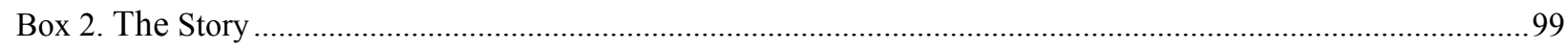

Box 3. Lack of Competition and Low Innovation: Example from Infant Formula ....................................................100 


\section{List of Abbreviations}

\author{
ASX Australian Securities Exchange \\ AT Agency Theory \\ AUS Australia \\ AUT Austria \\ BEL Belgium \\ BL Backward Linkage \\ CAN Canada \\ CEO Chief Executive Officer \\ CHE Switzerland \\ DEU/GER Germany \\ DNK Denmark \\ EC Efficiency Change Index \\ ESP Spain \\ FIN Finland \\ FL Forward Linkage \\ FRA France
}

GBR/UK United Kingdom

GDI Gross Domestic Income

GDP Gross Domestic Product

GRC Greece

ICT Information Communication Technology

INOWN Insider Ownership/Managerial Ownership

INSTO Institutional Investors

IRL Ireland

ISL Israel

ITA Italy

JPN Japan

KOR Korea

LUX Luxembourg

M Original Malmquist Productivity Index

MBIE Ministry of Business, Innovation and Employment

MED Ministry of Economic Development

MI Malmquist Productivity Index

ML Malmquist-Luenberger Productivity Index

MPS Management Practice Score

NLD Netherland

NOR Norway

NZ New Zealand
NZX New Zealand Exchange

OECD Organisation of Economic

Development

OUTBLOWN Outside Block Ownership

PPP Purchasing Power Parity

PRT Portugal

Q Tobin's Q

R\&D Research and Development

ROA Return on Assets

RSHC Returns on Shareholdings' Capital

SM Sequential Malmquist Productivity Index

SMEs Small-Medium Enterprises

SML Sequential Malmquist-Luenberger Productivity Index

SWE Sweden

TC Technical Change Index

TFP/MFP/PC Total Factor Productivity/ Multifactor Productivity/ Productivity Change

USA/US United States

VAL Valuation Ratio

WTO World Trade Organisation

\begin{tabular}{|r|l|}
\hline \multicolumn{2}{|c|}{ Important Terms } \\
Relation & $\begin{array}{l}\text { The cross sectional relationship } \\
\text { between insider/managerial } \\
\text { ownership and Tobin's Q, proxy } \\
\text { for managerial effectiveness. }\end{array}$ \\
\hline MPS & $\begin{array}{l}\text { An interview-based evaluation tool } \\
\text { for assessing managerial practice, } \\
\text { which defines and scores from 1 } \\
\text { (worst practice) to 5 (best practice) } \\
\text { across 18 of the key management } \\
\text { practice questions. }\end{array}$ \\
\hline $\begin{array}{r}\text { The 'Upper } \\
\text { Half' of the } \\
\text { OECD } \\
\text { countries }\end{array}$ & $\begin{array}{l}\text { The simple average of the highest } \\
\text { 17 OECD countries in terms of } \\
\text { GDP per capita, GDP per hour } \\
\text { worked and GDI per capita (in } \\
\text { constant 2005PPPs). }\end{array}$ \\
\hline cf & $\begin{array}{l}\text { Latin word - 'confer'; in English it } \\
\text { is read aloud as “compare”. }\end{array}$ \\
\hline
\end{tabular}




\section{Introduction}

The study by Barnes et al. (2013) pulls together previous empirical studies mostly carried out by the Organisation for Economic Cooperation and Development (OECD) to construct a framework that assesses the impact of a wide range of structural policy reforms on Gross Domestic Product (GDP) per capita at various horizons for a number of OECD countries, including New Zealand. The report suggests that given New Zealand's policy settings in the areas of taxation, regulation, innovation and education affecting GDP per capita New Zealand's GDP per capita, as predicted by these relationships, should be about $20 \%$ above the OECD average. This, however, is not the case. New Zealand's GDP per capita is actually $20 \%$ below the OECD average. The question of 'why' that is the case has generated spirited debates among academia and public policy exerts seeking to provide an answer to this age-old paradox.

Previous studies in this area pin the reasons behind such phenomenon down to three factors. They are weak international connections, low innovation and low managerial quality (New Zealand Productivity Commission, 2014a). Experts argue that New Zealand is indeed lacking in these aspects and that New Zealand needs to do more in these areas to improve its productivity performance (Grant Thornton, 2014; Rotherham, 2014). However, the question of 'why' that is the case remains relatively unanswered. 'Why' it is that many of New Zealand individual decision makers make the decisions that lead to such poor performance in these areas? What factor(s) cause New Zealand decision makers to make different choices to similar people operating in other OECD countries, who opt to be more active in the international market, invest much more heavily in Research and Development (R\&D), and in management?

The argument of being small and geographically isolated as a factor impeding New Zealand's economic performance, preventing better engagement in the international market, investment in R\&D and in management, may not hold water. Before the 1970s, New Zealand was among the richest per capita GDP countries in the world. The 'New Zealand Economy' was even smaller then and located exactly where it is now. Hence, by analytically piecing together key results and findings from available data, literature and empirical studies, this paper aims to construct a richer picture to help better explain the mechanism behind the puzzling phenomenon of New Zealand's productivity performance. 
The rest of the paper is organised as follows. Section 2 describes 'The New Zealand Productivity Puzzle' and explores the fundamental determinants behind New Zealand's relatively poor productivity performance. Section 3 discusses the debates among experts on this topic and proposes New Zealand's productivity under-performance as an issue of firm/corporate governance related to (A) managerial competency and (B) managerial effectiveness. The former measures the ability of managers to be successful and efficient, while the latter considers the degree to which such ability translates into desired outcomes. Section 4 and 5 investigate each of these two factors in detail, providing evidence for the above proposition and the extent to which these factors (managerial competency and managerial effectiveness) explain New Zealand's firm and related productivity under-performance. Section 6 explains how New Zealand's relative low firm performance due to these factors cause New Zealand to be less active in the international market, invest much less in $\mathrm{R} \& \mathrm{D}$, and in management. I argue how this can potentially account for New Zealand's relative weak international connections, low innovation and low managerial quality, the three main determinants (symptoms) of poor productivity performance in New Zealand (New Zealand Productivity Commission, 2014a). Section 7 provides the conclusion.

\section{The New Zealand Productivity Puzzle Overview}

A common understanding is that a country's per capita income rank 100 years ago is a reasonable predictor of where that country ranks today, for the most part, countries that were very rich then still are today (Glaeser et al., 2009). However, New Zealand (NZ) along with Uruguay, Romania and Argentina are amongst the key exceptions to this rule. Angus Maddison ${ }^{1}$, a renowned economic historian of global macroeconomic trends, estimated that in 1913 NZ's per capita income were among the two or three highest in the world, rivaling those in the United States and Australia (as cited in OECD, 2013). Even in the 1950, NZ incomes were still among the very highest in the world. However, of the countries that had relatively advanced economies in 1913, now only Uruguay, Romania and Argentina experienced greater relative falls than NZ. Unlike these countries, NZ has been a stable democratic country with a functioning market economy and the rule of law over the entire century. NZ's underlying productivity underperformance despite its strong institutions is a puzzling phenomenon, an age-old question, which many experts have sought to explain. Yet, until now the reason behind such puzzle is still not well understood (OECD, 2013).

\footnotetext{
${ }^{1}$ Maddison's data are available at http://www.ggdc.net/maddison/orrindex.htm
} 
The study by Barnes et al. (2013) made use of the empirical studies carried out previously by the OECD on the impact of a wide set of structural policy indicators on economic performance through each of the sub-components of GDP to develop a simple simulation framework. The framework is built around the identity that the differences in GDP per capita growth is the sum of the differences in labour productivity (defined as GDP per hour worked), average hours worked (per employed person), the employment rate (employment as a share of working age, 15-64) and the dependency ratio (the share of the working age population in the total population $)^{2}$. In so doing, this framework takes into account the multiple channels through which structural policies may affect economic performance to produce estimates of their overall effects on GDP per capita growth.

The study's model is built on the assumption that structural policies improvement means having low tax, less stringent market regulations, high R\&D incentives, a more open economy and more educated workforce. These are all characteristics of better quality institutions (rule of the game or humanly devised constraints - North, 1990) suggested to create the businessfriendly environment essential for growth and productivity to occur (consistent with the growth theory with a focus on institutions literature; see North \& Thomas, 1973; North, 1990; Acemoglu et al., 2005) $)^{3}$. In theory, given NZ's relatively better policy settings in these areas NZ's GDP per capita growth should be above the OECD average. More importantly, NZ's GDP per capita growth should be at a higher rate today than in the past because, on many counts, NZ has had better policies after the economy's radical reform in the 1980s and 1990s (OECD, 2008). This, however, is not the case. NZ's GDP per capita and productivity performance is actually below the OECD average and they are lower today than in the past, despite NZ's relative better policy settings today, and hence 'The New Zealand Productivity Puzzle'.

\footnotetext{
${ }^{2}$ The study by Barnes et al. (2013, p. 6) - Equation 1: $\Delta$ gdp per capita $=\Delta$ labour productivity $+\Delta$ hour worked + $\Delta$ employment rate $+\Delta$ working population; where $\Delta$ (delta) denotes the differences vis-à-vis a baseline scenario with no reforms and lower case variables denote logs of their upper case counterparts (i.e. GDP per capita, LABOUR PRODUCTIVITY, HOUR WORKED, EMPLOYMENT RATE, WORKING POPULATION).

${ }^{3}$ For more information on institutions see Tong, S. (2013). Does the Failure of a Staple Economy Imply the Failure of 'The Staple Theory'? A Comparative Analysis of New Zealand and Argentina (1890-1960) (unpublished honours dissertation). Victoria University, Wellington. Article available upon request from p_sodany@yahoo.co.uk.
} 
Acemoglu et al. (2005) voluminous survey of the growth literature's focusing on institutions supports the hypothesis that economic institutions explain significant portions of the observed differences in per capita GDP. Though in the literature institutions may be termed 'economic institutions' (Acemoglu et al., 2004), 'structural policies' (Persson, 2005), 'social infrastructure' (Hall \& Jones, 1999), or simply 'institutions' (Rodrik et al., 2004), they are all similar measures with different labels (Eicher \& Röhn, 2007). What label the author(s) prefer simply depends on the aspect of institutions he/she wished to emphasise. For instance, Persson (2005) prefers the label 'structural policy' to emphasise that regulatory and trade regimes result from purposeful collective choices under a set of more fundamental political arrangements (consistent with the argument of Glaeser et al., 2004). Whatever the label may be, for the above authors, they are used to refer to identical or very similar fundamental data. That is, institutional indicators originate from reliable sources such as the World Bank, the OECD, the International Risk Country Guide, the Fraser Institute (Eicher \& Röhn, 2007) and the like.

Recent growth theory's focus on institutions also suggest that besides explaining differences in per capita income, institutions may account for the variations in observed crosscountry growth rates. Adam Smith $(1776 ; 1937)$ proclaimed that the path to economic prosperity starts with a general presumption of economic freedom (or free economies) from government intervention (see also Dawson, 2007; Bundă, Moise-Ţiţei \& Jaliu, 2012). Thereafter, the classical liberal economists like Hayek (1954) and Friedman and Friedman (1980) continued the tradition under the terms capitalism and freedom of choice. In 1973, following the seminal work of Douglas North and Robert Thomas the link between institutions and economic performance quickly emerged to the centre of much academic discussion of growth theory. The institutions based literature on economic growth originates with the seminal work of Douglas North and Robert Thomas (1973) who argue that factors such as capital accumulation or innovation 'are not causes of growth...they are growth' (North \& Thomas, 1973, p. 2). More specifically, they argue for the following causal relation:

Institutions $\rightarrow\left\{\right.$ TFP $^{4}$, Human Capital, Physical Capital $\} \rightarrow$ Economic Development

\footnotetext{
${ }^{4}$ Total Factor Productivity (TFP), also refer to as Productivity Change (PC) or Multifactor Productivity (MFP).
} 
North and Thomas (1973) describe the proximate factors: innovation (TFP: Total Factor Productivity), education (Human Capital) and capital accumulation (Physical Capital), corresponding to factors of production embodies in the aggregate production function, as not causes of growth but growth in themselves. They made clear in their arguments that no doubt rich countries have greater levels of TFP (innovation), human capital (more educated workers), and physical capital (more machines, tools, factories, etc.), but these they argue are simply what it means to be prosperous. They are not an explanation of the sources of differences in prosperity. In their view, in order to explain the sources of differences in prosperity one must answer the questions why some countries are so much more innovative than others, why they invest much more resources into educational systems, and why people save and invest to accumulate physical capital. North and Thomas (1973) propose institutions to be the underlying explanation for these. They argue economic growth (defined as a per capita long-run rise in income/GDP) will simply not occur unless the existing economic organisations are efficient. Such proposition defines the basic logic of institutional theorists of economic growth, whereby the cause of economic growth is to be found in the economic organisations and that efficient economic organisations are necessary for economic growth (Huang, 2009).

Brou and Ruta (2006) also provide evidence for this argument. They show in an economy with poor institutions rent seeking activities (the resource-wasting behaviours of individuals and groups seeking wealth transfers $)^{5}$ reduce the growth rate in two ways. Firstly, when firms use real resources in rent seeking instead of investing them in production and research and development (R\&D), such wastage of resources on unproductive activity would reduce the growth potential of the economy. Secondly, a negative effect on the economy's market structure would result if the returns from rent seeking activity expenditures did not outweigh the economy's losses of resources associated with such behaviour. Such a reduction in gross profits forces some firms out of the market. Less market competition reduces the incentive of active firms to innovate. A lower level and rate of innovation and hence technological progress would negatively affect the long-run rate of growth of an economy. By contrast, Brou and Ruta (2006) show that in an economy with well-functioning institutions, where markets are economical and less stringent, the effect of rent seeking on market structure would be positive as competition forces firms to compete for market share through cost reducing technological innovation. A

\footnotetext{
${ }^{5}$ For more detail analysis on rent seeking behaviours see Tong, S. (2013). Does the Failure of a Staple Economy Imply the Failure of 'The Staple Theory'? A Comparative Analysis of New Zealand and Argentina (1890-1960) (unpublished honours dissertation). Victoria University, Wellington. Paper available upon request from p_sodany@yahoo.co.uk.
} 
higher level and rate of innovation and hence technological progress would positively affect the long-run rate of growth of an economy. This can counteract the first negative effect of real resource wastage on growth. Hence, institutions in this sense may be described as humanly designed to shape the incentive structure that can be either positively propel or negatively impede the productive activity and thus development of a given economy (North, 1990).

More recently, Baumol's (2002) distinction between productive and destructive entrepreneurship also indicates that rent seeking would be discouraged if institutions facilitate and reward innovative private sector activity and provide no incentives for rent seeking political favours. Even in Gwartney and Lawson's (2007) empirical study, prosperity has been accredited to good institutions that incentivise people to engage in productive entrepreneurship instead of destructive rent seeking ones. The growing evidence on the benefits of institutions to date suggests that institutional quality does matter and that, perhaps more than anything else, it is the institutional framework of an economy and the implied incentive structure that explain the welfare of a nation (Rohwer, 2011).

However, because of the inherent difficulty in measuring institutions there remains a lack of attention on institutions in the empirical growth literature. Unlike capital and labour, institutions are not directly measurable. Hence, research into the institutional determinants of economic performance largely use indicators that proxy for specific variables of interest (Eicher \& Röhn, 2007). Nevertheless, over the years, a wide body of OECD and other empirical evidence regarding the effects of structural reforms on various aspects of economic performance has been accumulated. The voluminous empirical findings accumulated over time enable Barnes et al. (2013) to develop a framework pulling these findings together. The simulation framework developed in Barnes et al. (2013) was constructed based on the voluminous empirical studies of the impact of a wide set of structural policy indicators ${ }^{6}$ on a broad range of indicators of economic performance ${ }^{7}$ which have shown to matter to economic growth. Through this mechanism Barnes et al. (2013) were able to directly predict the impact of structural policies on economic performance and thus the overall GDP per capita growth for a number of OECD countries, including NZ.

\footnotetext{
${ }^{6}$ I.e. labour and product market regulations, human capital, social transfer programmes, tax systems, trade and foreign direct investment policies, $R \& D$ incentives.

${ }^{7}$ I.e. TFP, factor accumulation, labour force participation, employment or hour worked.
} 
From an early stage, the availability of cheap stock from neighbouring Australian colonies and ample pasture shaped New Zealand's (NZ's) predominantly agricultural economy. The historiography of NZ for the years from 1890 has highlighted the role of refrigerationrelated pastoral exports in transforming the nation economic prospect (Te Ara, 2012a). In NZ, the introduction of refrigeration technology has led to a distinctive staple export boom, of dairy and meat products. The higher incomes generated from such export boom not only increased margins of cultivation (cf. typically result), but the effect went much deeper, leading not only to improvement in NZ's agricultural sector productivity but also to economy wide productivity improvement (Hussey \& Philpott, 1969; Hawke, 1985; Greasley \& Oxley, 2009). Such prosperity was largely attributable to the establishment of co-operative institutional arrangements, which arose as a natural solution to the problems concerning coordination, control and ownership occurring under the market conditions where numerous, small producers compete to supply large, concentrated agricultural processors, and where distributors also have some market power due to product perishability (Evans \& Meade, 2005).

Co-operative institutional structure ${ }^{8}$ essentially brought together thousands of fragmented NZ farmers supplying commodities for sale to powerful international customers. This allowed NZ dairy processors, and meat freezing alike, to achieve economies of scale in transaction costs and synergies from pooling resources. Such collective strength also enables farmers to overcome market inefficiency (Evans, 2012). Market inefficiency may arise from high farm input costs and because of the perishable nature of primary products. In the former case, NZ's co-operative farmers responded by investing together upstream to create buying groups for their key farm inputs, and subsequently giving rise to the formation of 'Combined Rural Traders'. In the latter case, the limited shelf life of primary products gives powerful buyers the ability to suppress the price for farm products. A co-operative institutional arrangement enables farmers to invest together in downstream assets to move the negotiation point away from where the farmer's product is perishable to a point where they have more bargaining power. This point is usually at the processor level, whereby the natural imbalance of power to suppress the price of milk does not reflect the risk taken to produce it.

\footnotetext{
${ }^{8} \mathrm{~A}$ co-operative is a type of institutional structure in which "those who transact with the organisation also own and formally control the organisation” (Evans \& Meade, 2005, p. 1; International Co-operative Alliance, 2014).
} 
Hence, the establishment of co-operative institutional structure enables the vertical integration of NZ's primary production, processing and marketing, allowing NZ producers to maximise the potential linkages between these industries and to capture their fair share of cash in the value chain by minimising market inefficiency (Greasley \& Oxley, 2009). Consequently, for many years (1890-1950), farming and its subsidiary servicing industries have provided NZ citizens with the dependable long run occupations and incomes. The economy also engaged in a modest diversification of exports to include commodities such as butter, cheese, timber and coal, predominantly sold to the United Kingdom (UK).

As political structure matured, the provincial governments were abolished and central government became responsible for all major decisions relating to the development and management of the NZ economy. Government policies in the late $19^{\text {th }}$ century encouraged further agricultural activity, which heightened export earnings from that sector (State Services Commission, 1998). Among these are policies that facilitated smallholdings. The rise of refrigeration that opened up export markets for meat and dairy products made small farming an economic proposition. Subsequently, NZ's government legislated policies aimed at dismantling the great estates in favour of closer settlement ${ }^{9}$ intended to aid the development of small farmers. The policy entailed the disposal of Crown land to genuine farmers, the extension of State leasehold and the repurchase of large estates for subdivision by the Crown. It has also entailed the introduction of land tax to enforce subdivision and cheap finance for the development of new farms. The Land for Settlement Acts of 1892 and 1894 were established to enforce the above policy objectives (Hylton \& Lucas, 1966). Consequently, the subsequent demand for improved infrastructure heightened public borrowing and a cycle of policies that produced a nation increasingly dependent on its agricultural sector.

Though the Great Depression of the early 1930s shocked NZ in the same ways as most other Western countries, as the international economy recovered, NZ's single minded production and export of commodities to its assured UK markets continued. NZ's preferential access to the UK market made prosperity an apparently permanent state of being for the well-insulated economy. Its citizens in this respect regarded NZ as "God's own country" (State Services Commission, 1998). However, NZ's lack of products and market diversification, reliance on a small range of products and a single major market made the economy vulnerable to shocks and it

\footnotetext{
${ }^{9}$ The term closer settlement refers to "the intensification and expansion of agricultural settlement and rural land use" (Davison \& Brodie, 2005).
} 
suffered deeply when substantial shocks flowed through the economy. Two major shocks occurred when the world wool price plummeted in the late 1960s, and then when the UK joined the European Economic Community, abandoning its 'Imperial Preference Scheme', which radically restricted access to NZ as a previously taken-for-granted market (Borkin, 2009).

By the early 1970s with prices for agricultural products on a worldwide high, a measure of economic prosperity somewhat returned only to be dampened again shortly after by the mid1970s oil price crises (see Figure 3). Subsequently, NZ's terms of trade fell by nearly half in a year. As government struggled to stabilize the economy, inflation rose into double figures, unemployment increased substantially and to top it all off, the previously healthy trade surplus became a billion dollar deficit within two years (State Services Commission, 1998). The NZ government, in turn, responded with an array of policies to maintain employment levels and control consumer prices through subsidies and regulations and to make NZ less dependent on imported energy sources. These initiatives were funded via high taxation and substantial overseas borrowings. In addition to extensive price controls from the war period, NZ's regulatory and trade policies also extended its pre-war isolationist stance on trade. Hence, throughout the twentieth century to 1984 , a centralised government control regime in NZ meant that NZ industries were heavily regulated (Claus, Lattimore, Le \& Stroombergen, 2011).

However, as each policy ran into difficulties the government responded with further controls and more regulations, leading eventually to a comprehensive 'wage and price freeze' (State Services Commission, 1998). Though the government held much control of the economy (more than many other market economies), the NZ economy had become all but stagnant (see Figure 3), an outcome consistent with the growth theory with a focus on institutions literature. This literature predicts that heavily regulated markets, high tax burden and high share of discretionary taxes, and restricted trade, were all characteristics of a more stringent business environment unlikely to encourage investment and innovation necessary for growth and productivity to occur (North \& Thomas, 1973). Thus, as expected in spite of these policies inflation remained high, unemployment increased, and real GDP per capita growth continued to stagnate. Consequently, by 1984 the NZ annual budget deficit and public debt was at an all-time high and the economy was at risk of a financial crisis. The only solution was a swift and radical reform of both the economy and the State (State Services Commission, 1998). 
The radical reform of the New Zealand (NZ) economy, since the late 1980s and early 1990s, has led the government to embark on a programme of sweeping liberalisation. The programme encompassed the removal of prices and exchange rate controls, the establishment of a broadly based low rate consumption tax, reduction of some punitive income and sales tax rates. The programme also abolished a whole range of agricultural and consumer subsidies and import licenses and export incentives. Attention then turned to the condition of the State. By the 1980s, the government owned a wide range of departments and trading enterprises, from winery to merchant and retail banks and commercial forests to utilities such as telecommunications, railways, electricity generation and marketing, and postal monopolies. All of these accounted for substantial GDP expenditure and gross investment but was providing very low returns (State Services Commission, 1998). By then it became clear that State owned and operated monopolies trading in tightly regulated markets were simply not going to provide the impetus needed for a vigorous and expanding economy.

Consequently, beginning in 1990s many of these trading enterprises were transformed by the government into state-owned enterprises, with the dual objectives of reducing the Crown's financial liabilities and achieving greater returns and efficiencies. The new approach to State enterprises at the turn of this century therefore encompassed corporatisation (or commercialisation), deregulation and privatisation (State Services Commission, 1998). Corporatisation began after the State Owned Enterprises Act 1986 was established. Deregulation of various industries began prior to 1986. The financial, media, and transport sectors were amongst the first to feel the effects of deregulation, and soon after the State dominant industries such as electricity generation and distribution, postal services and the telecommunications sector were deregulated. Privatisation was intended to redefine the 'role of the State' and fiscal principles, recognising that ministers were not in the best position to make essentially commercial decisions and that privatisation would reduce the demand for government capital for development purposes and the subsidisation of inefficient operations.

Following the radical reform of the 1980s and 1990s, NZ has transformed its economy from being among the most heavily protected and regulated into one of the most market-oriented and open internationally (WTO, 1996 as cited in Evans \& Richardson, 1998). For example, in 1996, the average applied tariff on all dutiable lines in NZ was only $10.3 \%$, a drop from the $27 \%$ 
rate two years earlier (Evans \& Richardson, 1998). To date tariffs on imported material have largely been removed, only a 5\% and $10 \%$ tariff duty applies to some goods. Furthermore, under NZ's existing free trade agreements, preferential tariffs might apply to goods imported from specific countries when certain conditions are met, and thus such goods would have an even lower rate of tariff duty than otherwise applied. Additionally, a good may also become duty free by way of a tariff concession, which is approved for goods where no suitable alternative is produced or manufactured locally (New Zealand Customs Service, 2014).

However, the economic transformation in NZ, whereby NZ went from a highly regulated economy to a highly deregulated one, greatly affected the business environment of agribusinesses. By the late 1980s, all input and output subsidies had been removed. The New Zealand Companies Act was rewritten in 1993 and following concerted lobbying by various agricultural leaders the New Zealand Co-operative Companies Act was rewritten in 1996 (previous Co-operative Companies Act 1956). The reform of the Companies Act in 1993 was part of the government initiative to improve the governance of securities by incentivising greater director accountability (Bhabra, 2007). This was intended to strengthen internal control, and hence discouraged managerial entrenchment ${ }^{10}$, which is necessary to improve firm performance. On the other hand, a key aspect of the Co-operative Companies Act 1996 is that co-operatives registering under this act are indeed companies and that such companies must operate according to the principle of mutuality with members having an implied common interest in working together for mutual benefit (Woodford, 2008). The Co-operative Companies Act 1996 was written as a companion act to the New Zealand Companies Act of 1993. Hence, the conditions of the latter also apply to the former unless specifically specified otherwise. This provides great flexibility to co-operatives and some co-operative companies specifically register under both acts without incompatibility. This reduced the costs of compliance.

The move to greater deregulation has also led to the dissolution of many of the statutory marketing boards with monopoly power in NZ. This, in effect, caused coordination problems in international marketing efforts of many NZ agricultural products (Dana \& Schoeman, 2010). The formation of large mega co-operatives representing a vast proportion of the nation's processors

\footnotetext{
${ }^{10}$ The entrenchment argument says higher equity ownership by the manager (or a certain individual or group) may decrease firm performance because large managerial ownership stakes (or when majority shareholder find it beneficial to work with management) make managers so powerful that they do not have to consider the minority other stakeholders' interest. They may also be so wealthy that they no longer intend to maximise profit but get higher utility from maximising market share etc. (Morck et al., 1988).
} 
of specific agricultural commodities was introduced as a solution to this problem. The formation of Fonterra required special legislation, the Dairy Industry Restructuring Act of 2001, to authorise the consolidation of NZ's two largest co-operatives (New Zealand Co-operative Dairy Company Ltd and Kiwi Co-operative Dairies Ltd). The New Zealand Ministry for Primary Industries administered this act. The act defined the resulting ownership of all the shares held by Fonterra in the New Zealand Dairy Board. The act also imposed specific conditions on Fonterra's operation, including open membership and some restrictions on its powers to dominate internal dairy markets within NZ. In conjunction with the Commerce Act 1986, this act requires an open entry and exit of farmers into and out of the co-operative and up to 600 million litres of raw milk made available to competitors. The latter is intended to prevent the monopoly position of Fonterra from being anticompetitive.

In summary, less stringent market regulations, lower taxations, a more open economy and more supportive policies to facilitate the development of key industries, all of these according to the growth theory's with a focus on institutions literature, would infer improved institutional quality. Hence, one might expect NZ's improved institutional quality based on its better policy settings after the 1980s and 1990s reforms, from full liberalisation of NZ's agricultural sector and trade or financial flows to least restrictive market regulations, to pay-off in terms of higher productivity growth. An outcome predicted by the stimulation framework developed by Barnes et al. (2013), whereby based on NZ's policy settings in the areas of taxation, regulation, innovation and education NZ's GDP per capita, as predicted by the framework, should be about $20 \%$ above the OECD average.

However, apart from providing effective boost to labour utilisation, McCann (2009) reports that NZ's GDP per capita and productivity have remained mediocre relative to many others advanced economies (see also Figure 1 to 4). Barnes et al. (2013) also report that NZ's GDP per capita observed in 2009 is actually about 20\% below the OECD average (see also Fallow, 2013; New Zealand Productivity Commission, 2014a). Thus, to the conclusion that NZ is a clear outlier to the extent to which actual GDP per capita growth has undershot its predicted rates based on policy settings (Barnes et al., 2013). In other words, despite NZ's good quality institutions, the economy GDP per capita is actually growing at a rate significantly below the OECD average. Figure 1 provides a graphical illustration of such a gap. 
Figure 1 below revealed some concerning features for New Zealand (NZ). It appears that given NZ's good structural and macro-policy framework, as judged by a wide body of OECD and other empirical studies underpinning the study by Barnes et al. (2013), NZ's GDP per capita should be much higher than Greece (GRC) and much closer to that of Australia's (AUS) and the United States' (US). However, NZ's GDP per capita observed in 2009 was actually closer to the level observed for GRC and much lower than the level observed for AUS and the US.

\section{Figure 1: The Gap Predicted from Various Structural Policies vs. Observed Gap in GDP Per Capita Relative to the OECD Average ${ }^{11}$}

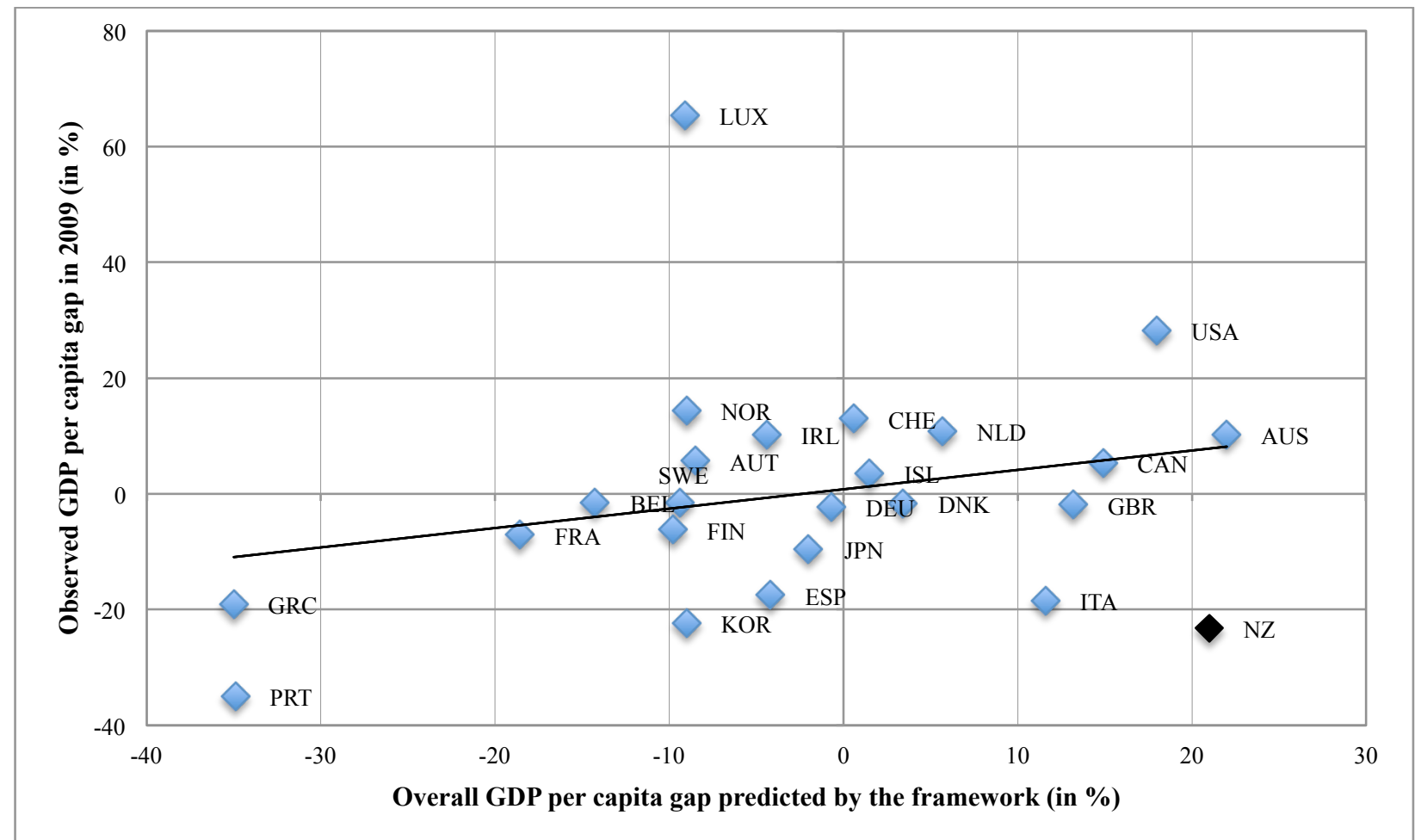

Note: The predicted overall GDP per capita gap was calculated on the basis of estimated impact of various structural policies (excluding product market regulation and labour protection legislation) from past OECD studies. The empirical studies that underpin the simulation framework identify the effects of policy settings on the basis of their time-series variation after controlling for all other unobserved factors (i.e. geography) contributed to explain crosscountry differences in performance. Key: NZ (New Zealand); GRC (Greece); PRT (Portugal); FRA (France); LUX (Luxembourg); BEL (Belgium); NOR (Norway); IRL (Ireland); SWE (Sweden); AUT (Austria); FIN (Finland); KOR (Korea); JPN (Japan); ESP (Spain); CHE (Switzerland); NLD (Netherland); CAN (Canada); AUS (Australia); GBR (United Kingdom); ITA (Italy); DNK (Denmark); ISL (Iceland); USA (United State); DEU (Germany). Source: graph constructed from data on the policy variable and the observed GDP per capita gap in 2009 (in \%) from Barnes et al. (2013).

\footnotetext{
${ }^{11}$ Luxembourg not included in the sample. Luxembourg presents a special case and is typically excluded from the regression because of the issue surrounding its GDP per capita being distorted by the fact that relatively large proportion of the country's workforce do not actually live in the country (small population) and the country's large amounts of external hot money invested in the Grand Duchy (see TheMoneyIllusion, 2010; Hennigan, 2014).
} 
Furthermore, it appears that over the past 40 years New Zealand (NZ) per capita GDP has slipped from being above the OECD average to around 20\% below it, as illustrated in Figure 2. Figure 2 below shows contrary to Australia (AUS), Norway (NOR), the United Kingdom (UK), the United States (US) and even Ireland (IRL) ${ }^{12}$ NZ's GDP per capita growth over time has not improved but declined. In fact, NZ's gaps in per capita GDP and productivity vis-à-vis the 'upper half of the OECD countries ${ }^{13}$ has widened significantly since the 1970s. Despite the deep structural reforms and good macro-policy framework in place after the 1980s-1990s reform, such gaps have not begun to close.

Figure 2: GDP Per Capita - New Zealand vs. Other Selected OECD Countries

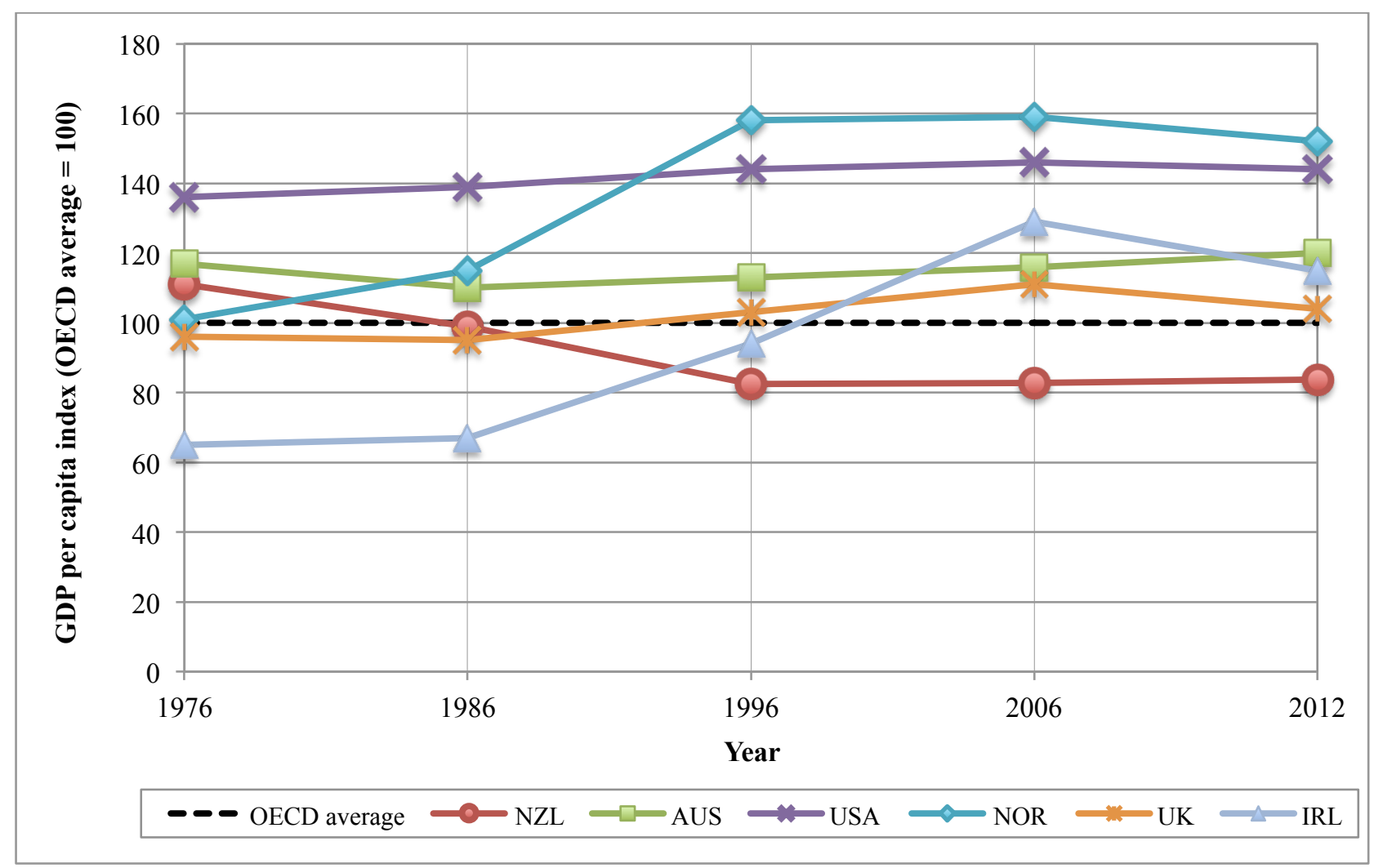

Note: 1996 to 2012 values calculated based on OECD (2014a) GDP per capita, US dollar, constant prices, 2005 PPPs. 1976 and 1986 values sourced from Te Ara - The Encyclopedia of New Zealand (2012b).

Even more concerning, the data seems to suggest that productivity in NZ is not catching up with other advanced economies. Figure 3 illustrates this. Figure 3 below shows the gaps in

\footnotetext{
${ }^{12}$ Ireland, a special case - through its drastic structural reforms during the Celtic Tiger period of 1996 to 2007 , has also increased its GDP per capita from a level well below the OECD average to a level higher than the OECD average (for detail see O'Connor, 2009).

${ }^{13}$ Defined by the OECD as the percentage gap with respect to the simple average of the highest 17 OECD countries in terms of GDP per capita, GDP per hour worked and GDI per capita (in constant 2005 PPPs) (see OECD, 2013). See ANNEX 1 - detail on the OECD countries. Statistical Link: http://www.oecd.org/eco/surveys/fig4_e\%20(2)\%20NZ2013.xlsx.
} 
NZ's per capita GDP and productivity vis-à-vis the upper half of the OECD countries ${ }^{11}$ has widened since the late 1970s and even more so during the 80s and 90s. After the 1990s, although the gap in NZ's per capita Gross Domestic Product/Gross Domestic Income (GDP/GDI) remained wide, data seems to suggest some sign of improvement (but at a very slow rate). The same cannot be said, however, for productivity. Since the 1990s, the gap in NZ's GDP per hour worked (proxy for labour productivity) has continued to widen. The divergence between NZ's GDP per hour worked and per capita GDP/GDI performance observed in Figure 3 occurred because since the 1990s NZ's GDP/GDI per capita performance had been driven by strong employment growth and improvement in the trade balance, while NZ's labour productivity has continued to fall relative to other OECD countries (Conway \& Meehan, 2013). Hence, offsetting the effect of declining productivity in NZ were its strong employment growth and terms of trade improvement.

\section{Figure 3: NZ's Gaps in Per Capita GDP and Productivity Persists: Gap to the Upper Half of OECD Countries ${ }^{13}$, Percent}

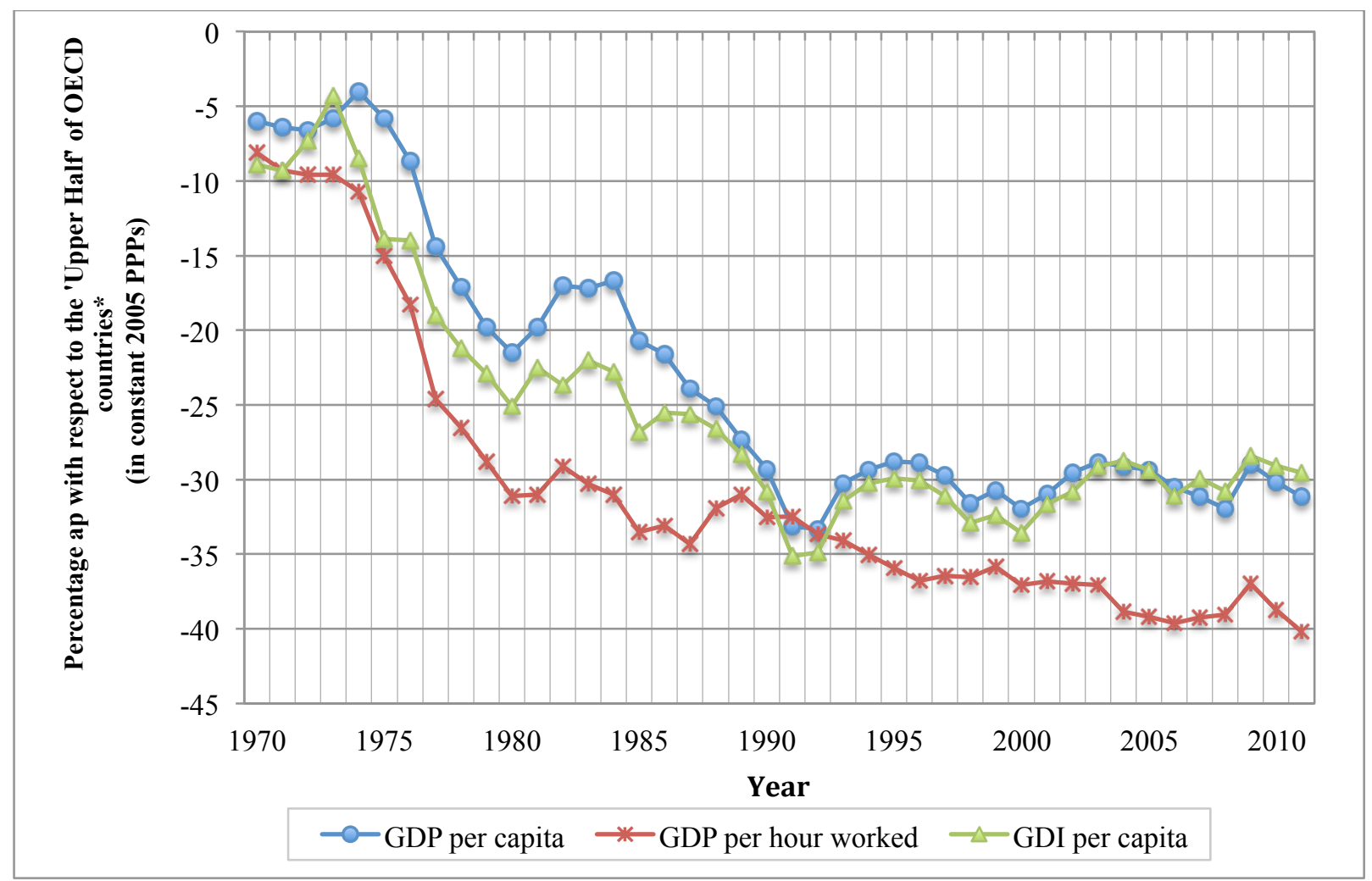

Note: The 'Upper Half' of the OECD countries is the simple average of the highest 17 OECD countries in terms of GDP per capita, GDP per hour worked and GDI per capita. Source: OECD (2013).

Though strong employment growth and improvement in terms of trade from the mid1990s have contributed to higher income growth, the prolonged and continuous divergence of 
NZ's productivity relative to other OECD countries highlights serious concerns for the NZ economy going forward. Of those concerns, one is the issue relative to the diffusion of technologies into the NZ economy. Another, more important issue, is that going forward as labour market participation and terms of trade gains reach their natural limits ${ }^{14}$ given the scarcity of resources and the limits to demand (D'Alessandro \& Drago, 2003; Osenton, 2004), without improvements in productivity performance, NZ's per capita GDP/GDI will stagnate.

\subsection{New Zealand's GDP Per Capita Gaps}

Figure 4 below confirms that the gaps in New Zealand's (NZ's) GDP per capita to a number of other most advanced OECD countries have not begun to close irrespective of the 1980s-1990s reform (except Greece, Italy and Spain).

\section{Figure 4: Per Capita GDP Percentage Gap Relative to New Zealand}

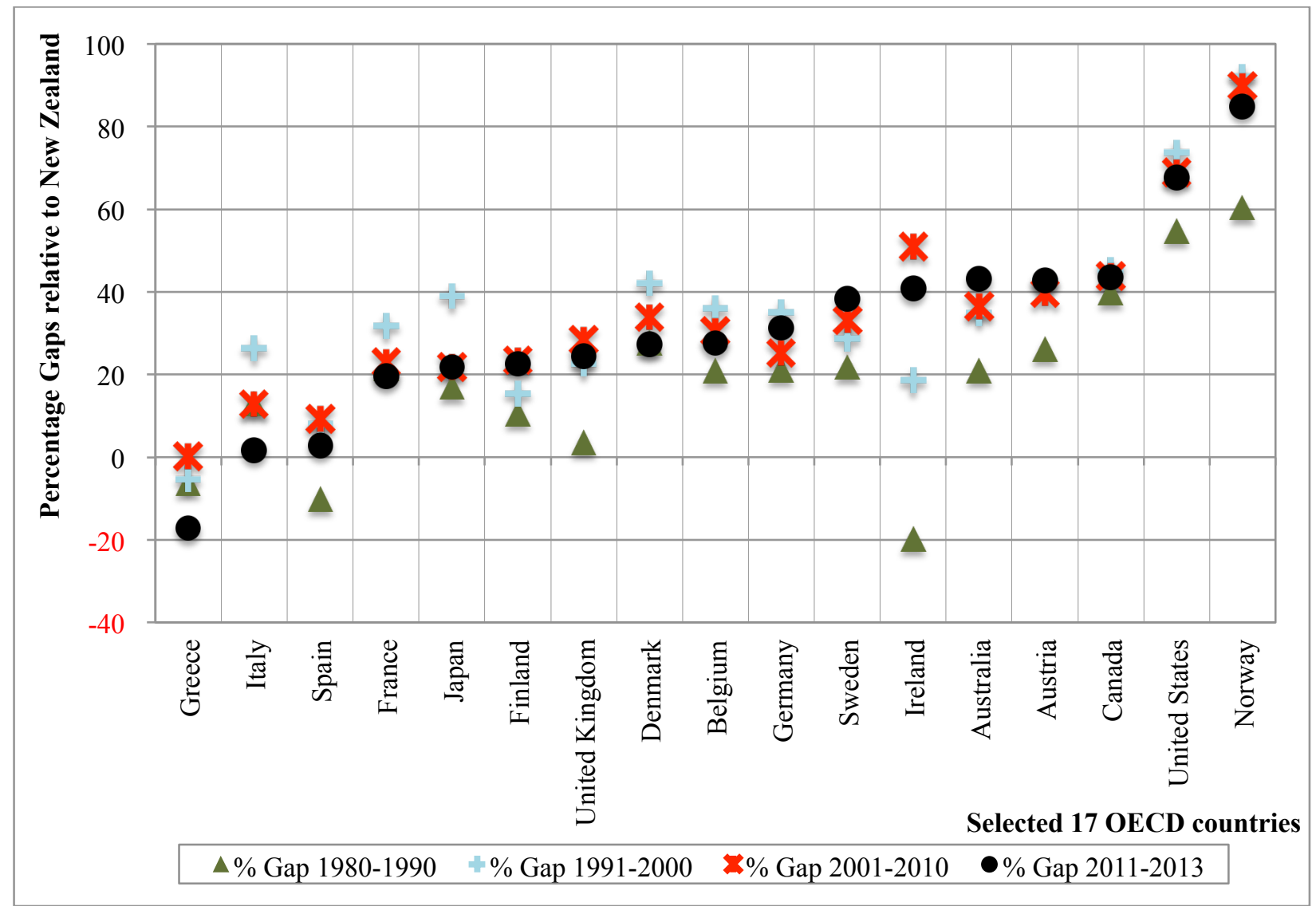

Note: The graph is constructed from data on 'Gross Domestic Product based on purchasing-power-parity (PPP) per capita GDP' for New Zealand and other 17 selected OECD countries obtained from the International Monetary Fund's World Economic Outlook Database, 2013.

\footnotetext{
${ }^{14}$ There is a physical (natural) limit to an economic level of living because of scarce natural resources.
} 
In recent times, measuring the change in productivity ${ }^{15}$ is carried out using index numbers, involving the measurement of changes in the level of outputs produced and inputs used. Index numbers measure the changes in the levels of a set of variables between a base period and the current period. Indices used for measuring productivity include Laspeyres (1871), Paache (1874), Fisher (1922), Törnquist (1936) and Malmquist productivity indexes (1953). Among these, Malmquist productivity index ${ }^{16}$ is one of the most extensively studied and developed in the non-parametric framework by several authors (see Caves et al., 1982; Färe et al., 1994; Chung et al., 1997; Shestalova, 2003; Oh \& Heshmati, 2010). This is because the problem with using Laspeyres, Paache, Fisher and Törnquist indexes ${ }^{17}$ to measure productivity change is that they all required quantity or price information to determine the weights as well as assumptions about the structure of technology and the behaviour of producers (Tone, 2004). These variables are relatively ambiguous, hard to measure and unobservable.

However, unlike Laspeyres, Paache, Fisher and Törnquist indexes, the Data Envelopment Analysis based (DEA-based) Malmquist productivity index (MI) makes use of output distance functions (the distance of an economy from its production frontier), comparing actual and potential production functions, to measure productivity change. It does so without constraining the results to fit any functional form of the production technology (Rao, 2004). Hence, in recent years the DEA-based MI productivity decomposition method has become standard in the investigation of productivity performance of firms and nations (Tone, 2004). In principle, MI approach enabled decomposition of 'Productivity Change' into 'Technical Change' and 'Efficiency Change' components. The index captures (a) the shift in the best-practice production frontier that indicates 'Technical Change', and (b) the shift in the firm's location relative to the production frontier indicating the 'Efficiency Change' that may arise from learning by doing, managerial practices improvement and change in efficiency under existing technology (Zheng, 2012).

\footnotetext{
${ }^{15}$ Productivity change (PC), Total Factor Productivity (TFP) and Multifactor Productivity (MFP) will be used interchangeably.

${ }^{16}$ Malmquist Productivity Index first introduced by Malmquist (1953) and further developed by several authors (including Caves, Christensen \& Diewert, 1982; Färe \& Grosskopf, 1994; Thrall, 2000) to analyse MFP changes of countries/firms over time (Tone, 2004).

${ }^{17}$ Laspeyres uses the base period quantities or prices as weights, Paache uses the current period weights; Fisher uses the geometric mean of Laspeyres and Paache indices and Törnquist uses a log-change form and represents the weighted average change in the log of the price or quantity of a particular commodity (Tone, 2004).
} 
Since the 1970s, a number of authors have also proposed and tested various modified versions of the MI for a selected sample of OECD countries for the period 1970-2003 (see Oh and Heshmati, 2010). These include the original Malmquist (denoted as M; see Färe et al., 1994), Sequential Malmquist (denoted as SM; see Shestalova, 2003), Malmquist-Luenberger (denoted as ML; see Chung et al., 1997), and Sequential Malmquist-Luenberger (denoted as SML; see Oh and Heshmati, 2010). Given the sample of countries and the time period examined in their studies, their empirical results provide a good snapshot of the NZ productivity position relative to other OECD countries for the period 1970 to 2003. Evaluating the accuracy and measurement of the original MI model against its various extensions and modifications is outside the scope of this paper, since the aim of this exercise is to provide inferences of the NZ productivity situation relative to its OECD counterparts. Hence, Figure 5 below provides the range of MFP (multifactor productivity; also called total factor productivity or productivity change) estimated under various Malmquist Productivity Index (MI) methodologies for the sampled OECD countries to which a general inference of where the original MI stands relative to its various modifications can be judged.

Figure 5 below illustrates that in general, for the majority of countries including NZ, the original MI (denoted as M) yield the lowest estimates of MFP among the various versions of MI. Whilst Sequential Malmquist-Luenberger (denoted as SML) yield the highest estimates of MFP. SML is a later modified version of MI. SML approach to 'Productivity Change' (MFP) measurement combines the concept of the successive sequential reference production sets and the concept of the directional distance function (Tulkens \& Vanden Eeckaut, 1995; Luenberger, 1992 as cited in Oh \& Heshmati, 2010, p. 1346). In SML's technology, technical change is assumed to enable more production of desirable outputs and less production of undesirable outputs. In so doing, Sequential Malmquist-Luenberger index (SML) is supposed to give a better measure of environmentally sensitive productivity growth that is free from spurious technical deterioration. While the original Malmquist index (M) is defined in terms of output distance functions, which seeks the greatest feasible expansion of all outputs, both good and bad, and where long run technical deterioration is possible (see Oh \& Heshmati, 2010). Unlike M, SML's technology assumed that technical deterioration is not possible. This explains why SML would yield relatively higher estimates of MFP than M (Finland and Norway however appear to be an exception to this rule). 
Figure 5: The Range of MFP Outcomes Across M, SM, ML and SML Approach, 1970-2003

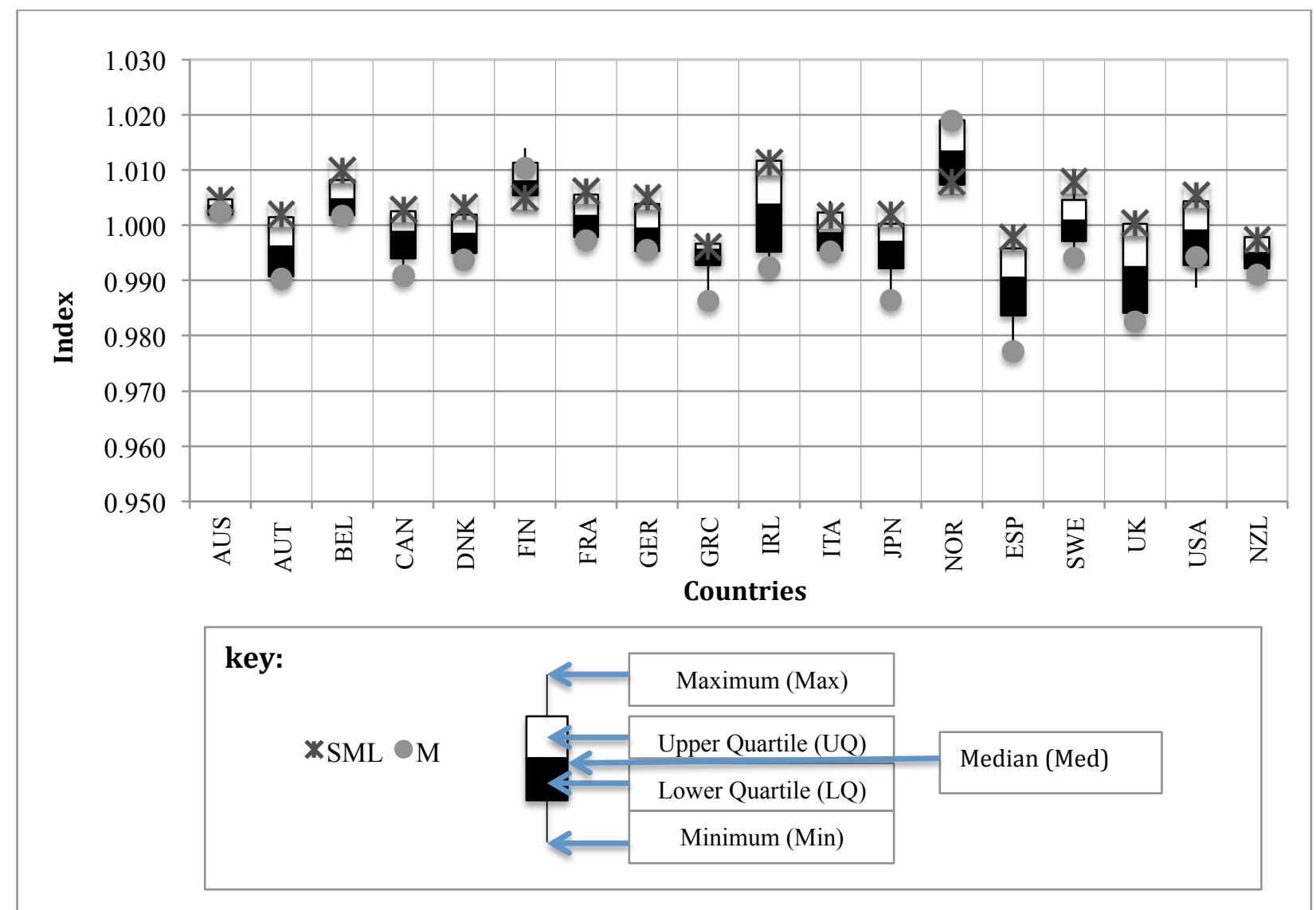

Note: M, SM, ML, SML denoted Malmquist (see Färe et al., 1994), Sequential Malmquist (see Shestalova, 2003), Malmquist-Luenberger (see Chung et al., 1997), and Sequential Malmquist-Luenberger (see Oh \& Heshmati, 2010), respectively. Key: countries' name abbreviation see note to Figure 1. Source: own collaboration constructed using data from Oh and Heshmati, 2010.

In Figure 5, the index value equals 'one' means that there have been no changes in productivity over the two time periods (e.g. time $\mathrm{t}$ and $\mathrm{t}+1$ ). If there has been an increase (decrease) in productivity the index value would be greater (less) than 'one', respectively. To that end, it can be inferred that even under the most optimistic estimates - SML - the index value for NZ being smaller than unity ('one') confirms that, on average for the period 1970-2003, productivity in NZ has been declining. Decomposing NZ's and the other OECD countries' MFP (Multifactor Productivity or 'Productivity Change') in Figure 5 into 'Efficiency Change' and 'Technical Change' allows one to look further into the issue. Figure 6 illustrates this. The result in Figure 6 highlights NZ's poor performance on these measures relative to the sampled OECD countries, even under the most optimistic view (SML - where technical deterioration is not possible). 
Figure 6: SML - Efficiency Change and Technical Change, 1970-2003

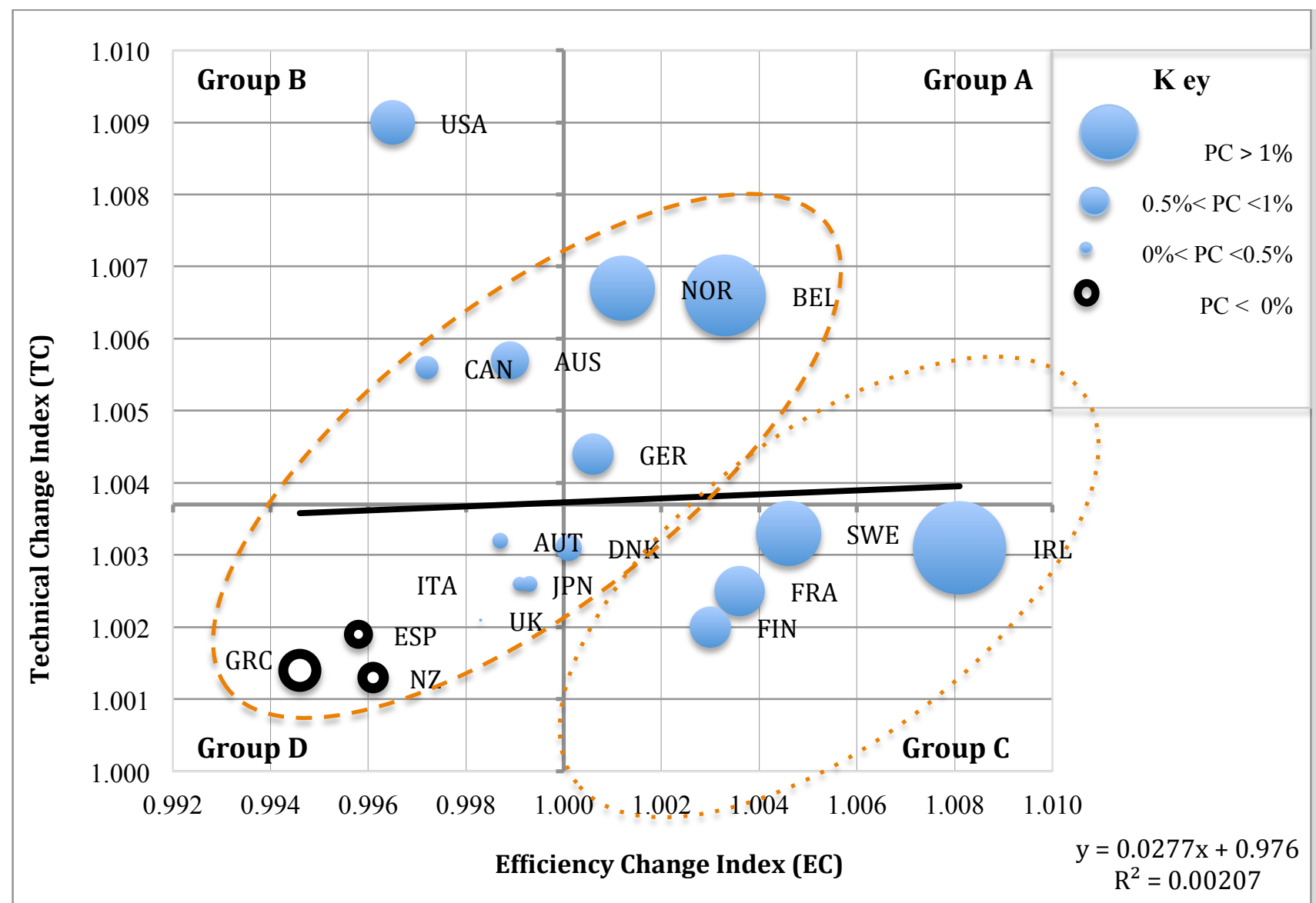

Note: SML denoted Sequential Malmquist-Luenberger Productivity Index. Blue (Black) circles denoted positive (negative) productivity change (\% growth), whereby the larger the circle the more positive (negative) is the percentage change in productivity. Ireland (IRL) is an outlier, an exception to the rule, to the extent that a drastic reform has taken place (see O'Connor, 2009). The positive correlation between 'Technical Change' and 'Efficiency Change' increases with the removal of IRL from 0.045 to 0.108 , but the relationship is still weak. Data source: Oh and Heshmati, 2010.

In Figure 6 above, SML productivity index is decomposed into 'Efficiency Change' and 'Technical Change' components. In this model 'Efficiency Change' represents the movement of a decision-making unit (countries in the study) towards the best practice frontier from time to $\mathrm{t}+1$. Whereby, Efficiency Change Index being greater (less) than one means there has been a catching-up movement (a movement away from) the frontier in period $\mathrm{t}+1$, and hence the economy in question has become more (less) efficient, respectively. On the other hand, 'Technical Change' measures the amount of a shift of frontier between $t$ and $t+1$. Recall under SML approach the Technical Change Index is not less than unity because technical deterioration is not possible. Hence, the Technical Change Index from time $t$ to $t+1$ is expected to be greater than one or otherwise equal one. This explains why Technical Change Index estimates for all countries under the SML approach are greater than unity/one. Consequently, in this set up, a 
given economy's relative Technical Change Index is assessed against the average Technical Change Index of the sample, not the unity value 'one'.

To this end, Figure 6 informs us if the Efficiency Change Index (EC) of a country is larger (less) than unity it is considered as being in the state of catching up (lagging behind) the world frontier technology. Likewise, if the Technical Change Index (TC) is larger (smaller) than the average technical change of the sample, its innovation ability can be considered as being better (worse) than the virtual average country. On this basis, one can categorises the sampled countries in Figure 6 into four groups. They are Group A: more innovative and catching up economies (TC > sample average and EC > unity); Group B: more innovative but lagged economies (TC > sample average and $\mathrm{EC}<$ unity); Group $\mathrm{C}$ : less innovative but catching up economies (TC < sample average and EC > unity); Group D: less innovative and lagged economies (TC < sample average and EC < unity) (Oh \& Heshmati, 2010). Consequently, NZ's relative low score on both Technical Change Index (TC) and Efficiency Change Index (EC) dimension in Figure 6 suggested that NZ would belong to 'Group D: less innovative and lagging behind' (1970-2003). Under such categorisation, one can interpret NZ's relative position on 'Productivity Change', 'Efficiency Change' and 'Technical Change' in Figure 6 as follows. Overall, Productivity Change (PC) in NZ was negative (approximately by $2.6 \%$ ). On the scale of Efficiency Change, NZ was below unity at the rate of 3.9\%. Though Technical Change in NZ being greater than 1 at 1.0013 this indicates that there is technical progress at an annual average rate of $1.3 \%$ for $1970-2003$, this rate is below the average annual rate achieved in the sampled OECD countries of $3.7 \%$. Hence, in sum one can infer that on average, between 1970 and 2003 NZ had been relatively less innovative and inefficient compared to other OECD countries. These in effect, accounted for NZ's relative poor 'Productivity Change' (PC) of negative $2.6 \%$ for the period $1970-2003^{18}$.

Note that United States' EC was also below unity in this sample. This may in part be due to the dotcom bubble burst and the 9/11 terrorist attack. Such events greatly affected United States' business operations between 2001 and 2003. Economies with United States (US) multinationals also experienced disruption to their operations, and thus experienced lower EC scores than expected otherwise. However, low EC observed for the US may also be due to the fact that EC is a measure of change (rate) not level. An economy such as the US that has experienced greater efficiency from the very early stages (cf. the beginning of industrialisation),

\footnotetext{
${ }^{18}$ For more information on Malmquist Productivity Index and productivity growth see Boussemart et al (2001).
} 
the incremental change in efficiency thereafter may be relatively small. The US high rate of TC observed in Figure 6 also reinforces this point by suggesting that high level of efficiency (from the very early stages and accumulated over time) may have facilitated the US's very high rate of TC. Likewise, a country that started with a very low level of efficiency would experience relatively larger changes. Ireland's dramatic improvement in EC after its drastic structural reform after a very long period of inefficiency confirms this (see O’Connor, 2009).

In line with this, a study by Pires and Garcia (2012) on the source of economic growth between 1970 and 2000 provided similar results. Pires and Garcia (2012) use a growth accounting method to decompose output growth (GDP) into labour and capital input growth and Multifactor Productivity (MFP) growth. They then adopted a stochastic frontier analysis (SFA) approach to obtain estimators of MFP components, before decomposing MFP (or Productivity Change) into its respective Efficiency Change and Technical Change components.

Table 1 below summarizes their results and informs us about NZ's relative poor position on the improvement in innovation (Technical Change growth ranked $15^{\text {th }}$ out of 17 ), in efficiency (Efficiency Change growth ranked $16^{\text {th }}$ out of 17) and in overall productivity (Productivity Change growth ranked $16^{\text {th }}$ out of 17) compare to its OECD counterparts for the period 19702000 (consistent with the finding of Oh \& Heshmati, 2010). Table 1 also informs us that, on average between 1970 and 2000, NZ's relative position in terms of growth in labour inputs was also high (ranked $4^{\text {th }}$ ), while NZ's growth in terms of capital inputs and Multifactor Productivity (MFP) were relatively low (ranked in the bottom percentile). This confirms that the driver of output growth in NZ during this period was due to strong employment growth. However, the lower capital to labour ratio and MFP in NZ suggests that NZ was relatively capital shallow and less productive compared to other OECD countries in the sample during 1970-2000. 
Table 1: Sources of Economic Growth 1970-2000 (in Average Annual Percentage Change)

\begin{tabular}{|c|c|c|c|c|c|c|c|c|c|c|c|c|c|c|}
\hline \multirow{3}{*}{ Country } & \multirow{2}{*}{\multicolumn{2}{|c|}{$\begin{array}{c}\text { Output } \\
\text { growth (1) }\end{array}$}} & \multirow{2}{*}{\multicolumn{2}{|c|}{$\begin{array}{c}\text { Capital } \\
\text { inputs (2) }\end{array}$}} & \multirow{2}{*}{\multicolumn{2}{|c|}{$\begin{array}{l}\text { Labour } \\
\text { inputs (2) }\end{array}$}} & \multirow{3}{*}{$\begin{array}{c}\text { Total } \\
\text { factors }\end{array}$} & \multirow[b]{2}{*}{$\begin{array}{l}\text { TFP/MFP } \\
\text { Productivity } \\
\text { Change (3) }\end{array}$} & \multirow[b]{3}{*}{$\mathbf{R}$} & \multicolumn{4}{|c|}{$\begin{array}{c}\text { Productivity Change Decompose into } \\
\text { Technical and Efficiency Change } \\
\text { Components }\end{array}$} & \multirow{3}{*}{$\varepsilon(3)$} \\
\hline & & & & & & & & & & $\begin{array}{l}\text { Technical } \\
\text { Progress }\end{array}$ & & $\begin{array}{l}\text { Efficiency } \\
\text { Change } \\
\text { (EC) }\end{array}$ & & \\
\hline & & $\mathbf{R}$ & & $\mathbf{R}$ & & $\mathbf{R}$ & & & & & $\mathbf{R}$ & & $\mathbf{R}$ & \\
\hline $\begin{array}{c}\text { AUS } \\
\text { (Australia) }\end{array}$ & 4.16 & 3 & 1.17 & 13 & 1.06 & 2 & 2.23 & 0.93 & 15 & 0.3 & 6 & 0.64 & 15 & 1 \\
\hline $\begin{array}{c}\text { AUT } \\
\text { (Austria) }\end{array}$ & 3.74 & 8 & 1.7 & 10 & 0.3 & 14 & 2 & 1.77 & 2 & 0.25 & 10 & 1.51 & 2 & -0.03 \\
\hline $\begin{array}{c}\text { BEL } \\
\text { (Belgium) }\end{array}$ & 3.29 & 13 & 1.6 & 12 & 0.31 & 13 & 1.91 & 1.4 & 8 & 0.23 & 12 & 1.16 & 6 & -0.02 \\
\hline $\begin{array}{c}\text { CAN } \\
\text { (Canada) }\end{array}$ & 4.14 & 4 & 1.87 & 6 & 1.1 & 1 & 2.97 & 0.98 & 13 & 0.26 & 9 & 0.72 & 14 & 0.19 \\
\hline $\begin{array}{c}\text { DNK } \\
\text { (Denmark) }\end{array}$ & 2.61 & 15 & 0.89 & 16 & 0.35 & 12 & 1.24 & 1.39 & 9 & 0.27 & 8 & 1.11 & 8 & -0.02 \\
\hline $\begin{array}{c}\text { FIN } \\
\text { (Finland) }\end{array}$ & 3.65 & 10 & 1.76 & 8 & 0.37 & 10 & 2.13 & 1.45 & 6 & 0.18 & 14 & 1.27 & 5 & 0.07 \\
\hline $\begin{array}{c}\text { FRA } \\
\text { (France) }\end{array}$ & 3.43 & 12 & 1.79 & 7 & 0.47 & 8 & 2.26 & 1.75 & 3 & 0.41 & 3 & 1.33 & 3 & -0.57 \\
\hline $\begin{array}{c}\text { GRC } \\
\text { (Greece) }\end{array}$ & 3.67 & 9 & 4.37 & 1 & 0.3 & 14 & 4.67 & -0.46 & 17 & 0.05 & 16 & -0.5 & 17 & -0.55 \\
\hline $\begin{array}{c}\text { IRL } \\
\text { (Ireland) }\end{array}$ & 6.03 & 1 & 2.18 & 4 & 0.61 & 5 & 2.79 & 0.97 & 14 & -0.05 & 17 & 1.01 & 10 & 2.27 \\
\hline $\begin{array}{c}\text { ITA } \\
\text { (Italy) }\end{array}$ & 3.53 & 11 & 2.14 & 5 & 0.29 & 16 & 2.43 & 1.24 & 12 & 0.35 & 4 & 0.89 & 13 & -0.14 \\
\hline $\begin{array}{c}\text { JPN } \\
\text { (Japan) }\end{array}$ & 5.26 & 2 & 3.54 & 2 & 0.58 & 6 & 4.12 & 2.42 & 1 & 0.56 & 1 & 1.83 & 1 & -1.28 \\
\hline $\begin{array}{c}\text { NOR } \\
\text { (Norway) }\end{array}$ & 4.09 & 5 & 1.75 & 9 & 0.4 & 9 & 2.15 & 1.53 & 4 & 0.25 & 10 & 1.28 & 4 & 0.41 \\
\hline $\begin{array}{c}\text { ESP } \\
\text { (Spain) }\end{array}$ & 3.97 & 6 & 2.79 & 3 & 0.54 & 7 & 3.33 & 1.3 & 11 & 0.23 & 12 & 1.06 & 9 & -0.66 \\
\hline $\begin{array}{c}\text { SWE } \\
\text { (Sweden) }\end{array}$ & 2.57 & 16 & 0.96 & 15 & 0.36 & 11 & 1.32 & 1.44 & 7 & 0.28 & 7 & 1.15 & 7 & -0.2 \\
\hline $\begin{array}{c}\text { UK } \\
\text { (United } \\
\text { Kingdom) } \\
\end{array}$ & 2.73 & 14 & 0.99 & 14 & 0.27 & 17 & 1.26 & 1.33 & 10 & 0.32 & 5 & 1 & 11 & 0.13 \\
\hline $\begin{array}{c}\text { USA } \\
\text { (United State) }\end{array}$ & 3.97 & 6 & 1.7 & 10 & 0.84 & 3 & 2.54 & 1.49 & 5 & 0.52 & 2 & 0.96 & 12 & -0.07 \\
\hline $\begin{array}{c}\text { NZ } \\
\text { (New Zealand) }\end{array}$ & 2.39 & 17 & 0.47 & 17 & 0.77 & 4 & 1.24 & 0.76 & 16 & 0.15 & 15 & 0.61 & 16 & 0.39 \\
\hline
\end{tabular}

Note: (1) Growth of GDP (output) = $\tilde{y}$; (2) Growth rates adjusted by income shares; (3) TFP/MFP/Productivity Change and random shock $(\varepsilon)$ obtained as residual of output growth and productivity change, respectively; $\mathrm{R}=$ rank where 1 = best. Efficiency Change (EC) is the sum of Technical efficiency (E), scale effects (S), and allocative efficiency (O). Source: Data extracted from Pires and Garcia (2012). Their model estimation was conducted using STAT. Their database consists of a non-balanced panel for aggregated output and production factors (capital and labour) of a sample of countries obtained from Penn World Tables version 6.1 (1950-2000). Data for factor shares were obtained from the System of National Accounts 1968 (United Nations, 2003) and from the Annual National Accounts of OECD (OECD, 2003) ${ }^{19}$.

Though indefinite growth in GDP cannot be sustained through input accumulation alone, capital accumulation (deepening) nonetheless has a direct impact on the level of output and productivity. This is because a rise in capital directly influences labour productivity by increasing the quantity and quality of machinery, equipment and infrastructure available to each worker (Hall \& Scobie, 2005). Hence, higher capital intensification would, in this sense, lead to

\footnotetext{
${ }^{19}$ Annual National Accounts for OECD Member Countries - Data from 1970 onwards. Table 3: GDP by Income, 2003.
} 
higher labour productivity and vice versa. If labour productivity increased (decreased) beyond the level of capital input growth (contract), due to better (worse) capital utilisation, MFP would be higher (lower). This in effect makes capital accumulation indirectly linked to MFP. Consequently, relatively low capital accumulation and intensification leading to low MFP, due to lack of investment and innovation, in NZ may very well explain the economy's relative economic under-performance. This is consistent with a point made by Kaldor $(1957 ; 1961$ as cited in Altman, 2013) that in many circumstances technological change requires capital accumulation or investment.

For New Zealand (NZ), its relative poor position illustrated in Figure 6 (or Table 1) is quite worrisome given that much of the fluctuation of NZ's output growth appears to be largely driven by MFP (as illustrated in Figure 7 below) and that MFP is an important driver behind NZ's labour productivity fluctuations (as illustrated in Figure 8 below). Even more concerning for NZ, an examination of Statistics New Zealand's industry productivity statistics 1978-2011 reveal an ongoing decline of NZ's average annual labour productivity change (see Figure 9 below), capital productivity change (see Figure 10 below) and MFP change (see Figure 11 below) in the primary, goods-producing and services industries since the 1997-2000s growth cycle $^{20}$ (Statistics New Zealand's productivity statistics: 1978-2013, 2014a; See Figure 7-8 note).

\footnotetext{
${ }^{20}$ Productivity data presented as annual averages within Growth Cycle. Estimating productivity growth over cycles is preferable because the methodology used in compiling the estimates implicitly assumes that the proportion of capital stock used in production (capital utilisation) does not change. Therefore, any real world change in the extent to which capital is utilised in production will be recorded as change in productivity.
} 
Figure 7: New Zealand's Productivity in the Measured Sector: Contribution to Output Growth from Capital Input, Labour Input and MFP, 1970-2013

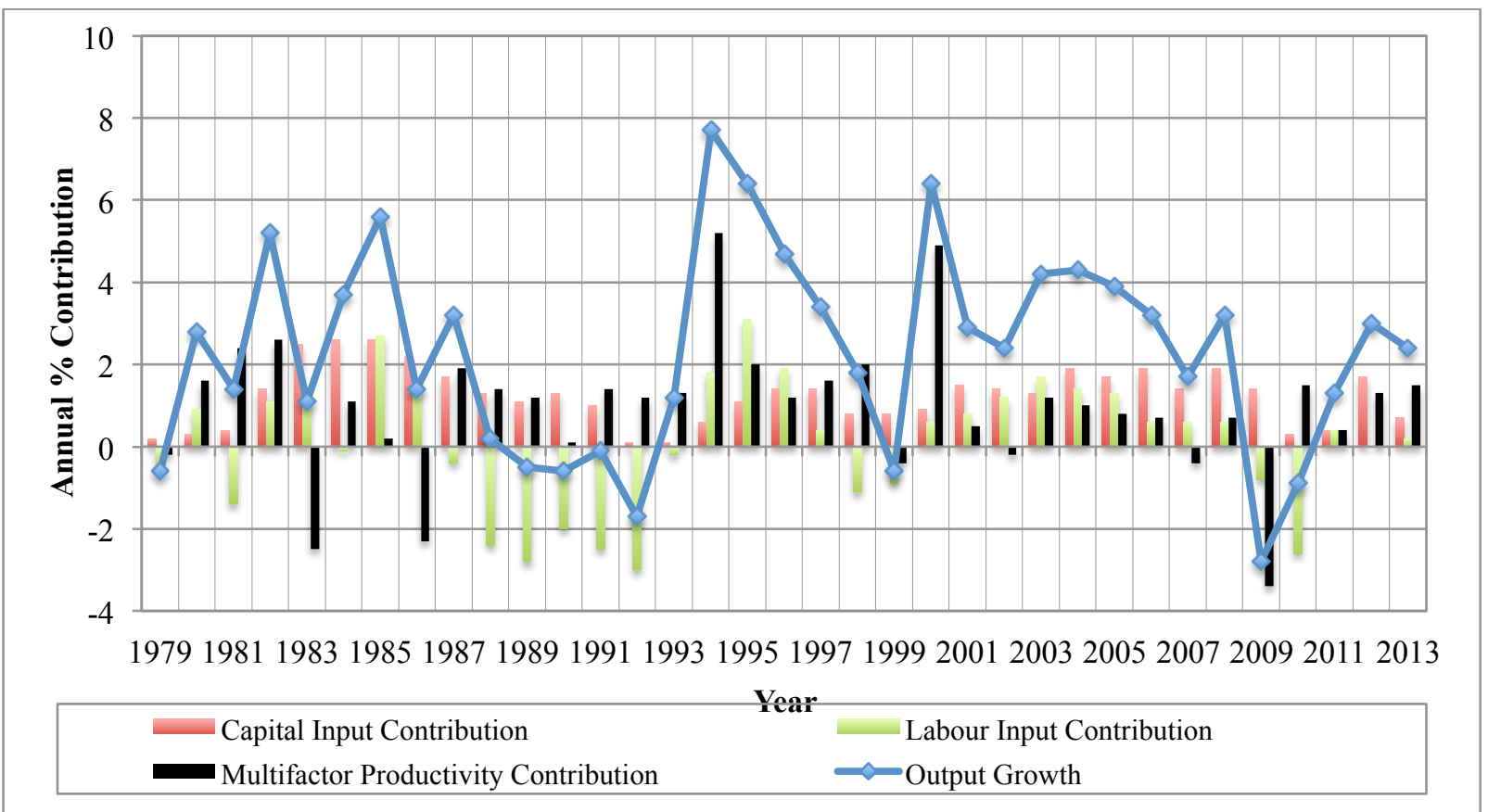

Figure 8: New Zealand's Labour Productivity Decomposition - Contribution from Capital Deepening and MFP, 1979-2013

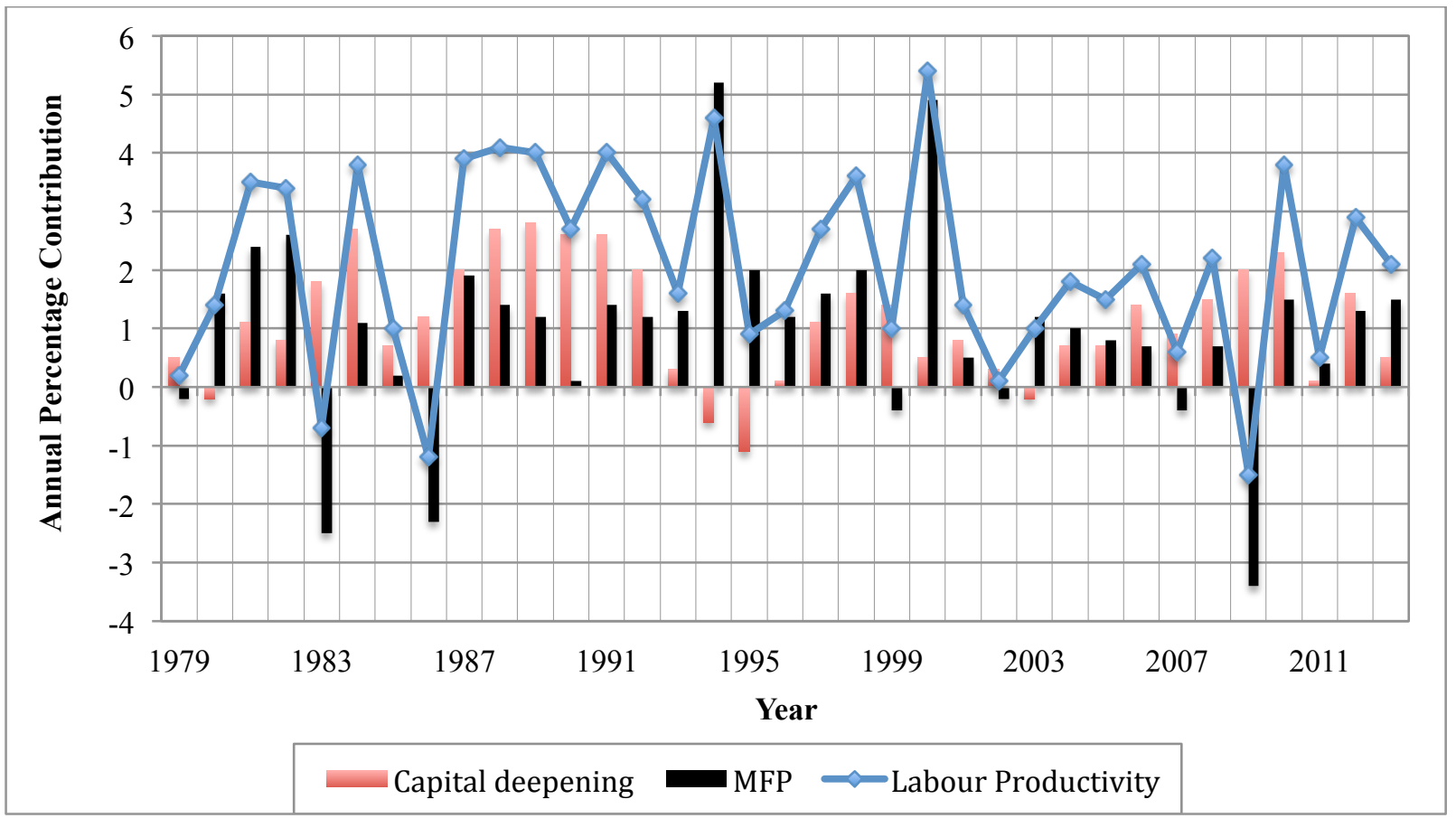

Figure $7-8$ Note: the measured sector is ANZSIC06 divisions, a subset of the economy. Industry coverage under ANZSIC06 included the primary sector (AAZ, BB1), goods-producing sector (CCZ, DD1, EE1), and service sector (FF1 to RS2); services available from 1996. See the data quality section on www.stats.govt.nz for more details ${ }^{21}$. Source: Graphs constructed using data from Statistics New Zealand's productivity statistics: 1978-2013 (2014a).

\section{${ }^{21}$ Direct:}

http://www.stats.govt.nz/browse_for_stats/economic_indicators/productivity/ProductivityStatistics_HOTP78-

13/Data\%20Quality.aspx\#industry 
Figure 9: Labour Productivity by Sector, 1978-2011

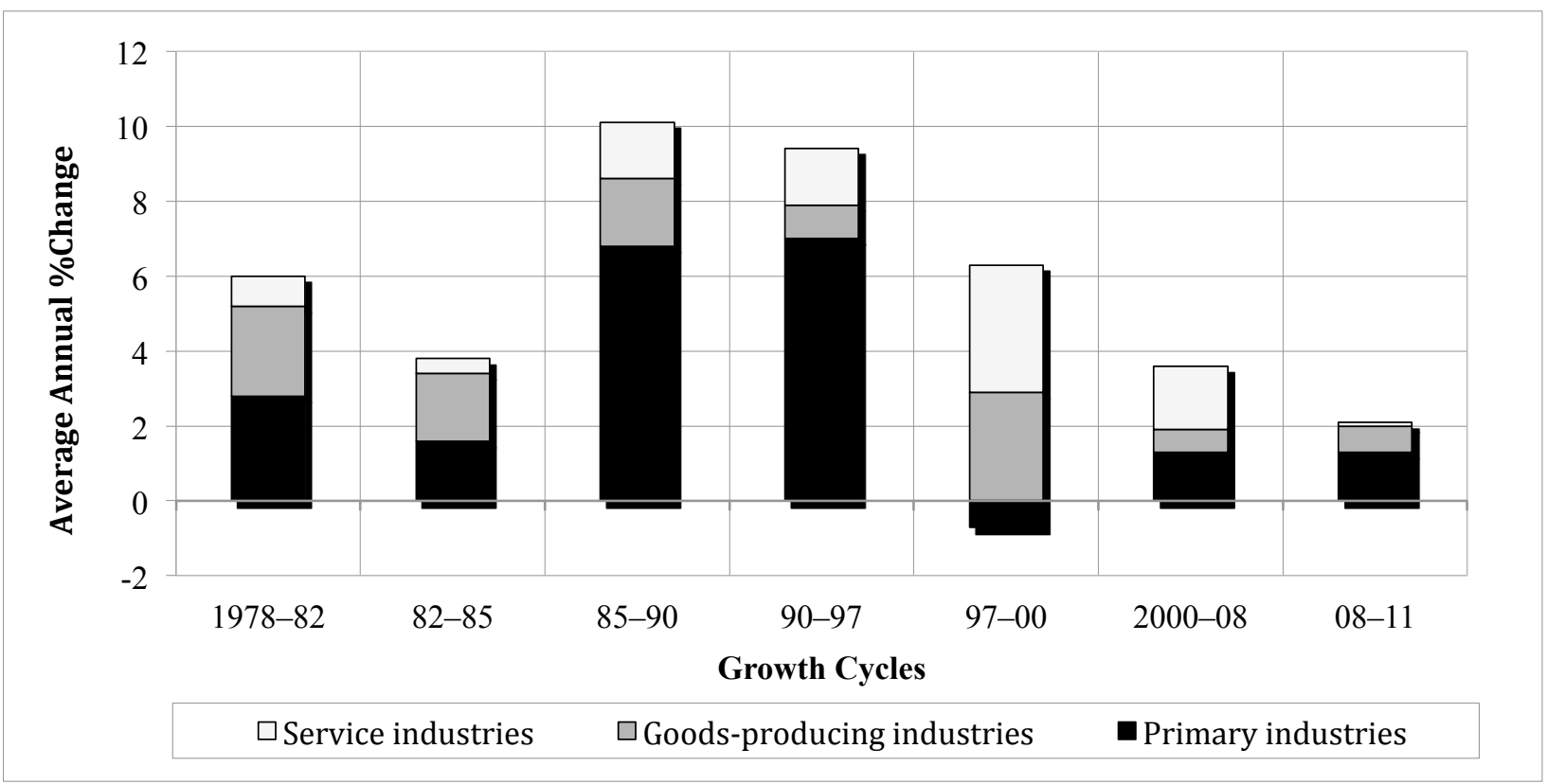

Figure 9 shows NZ's primary industries, goods-producing industries and service industries all faced ongoing decline in labour productivity growth since the 1990-97 Growth Cycle. Among these the primary sector has experienced the greatest fluctuation in average annual growth rate by Growth Cycles. Data Source: figure derived from data made available by Statistics New Zealand's Industry Productivity Statistics: 1978-2011 (2013).

\section{Figure 10: Capital Productivity by Sector, 1978-2011}

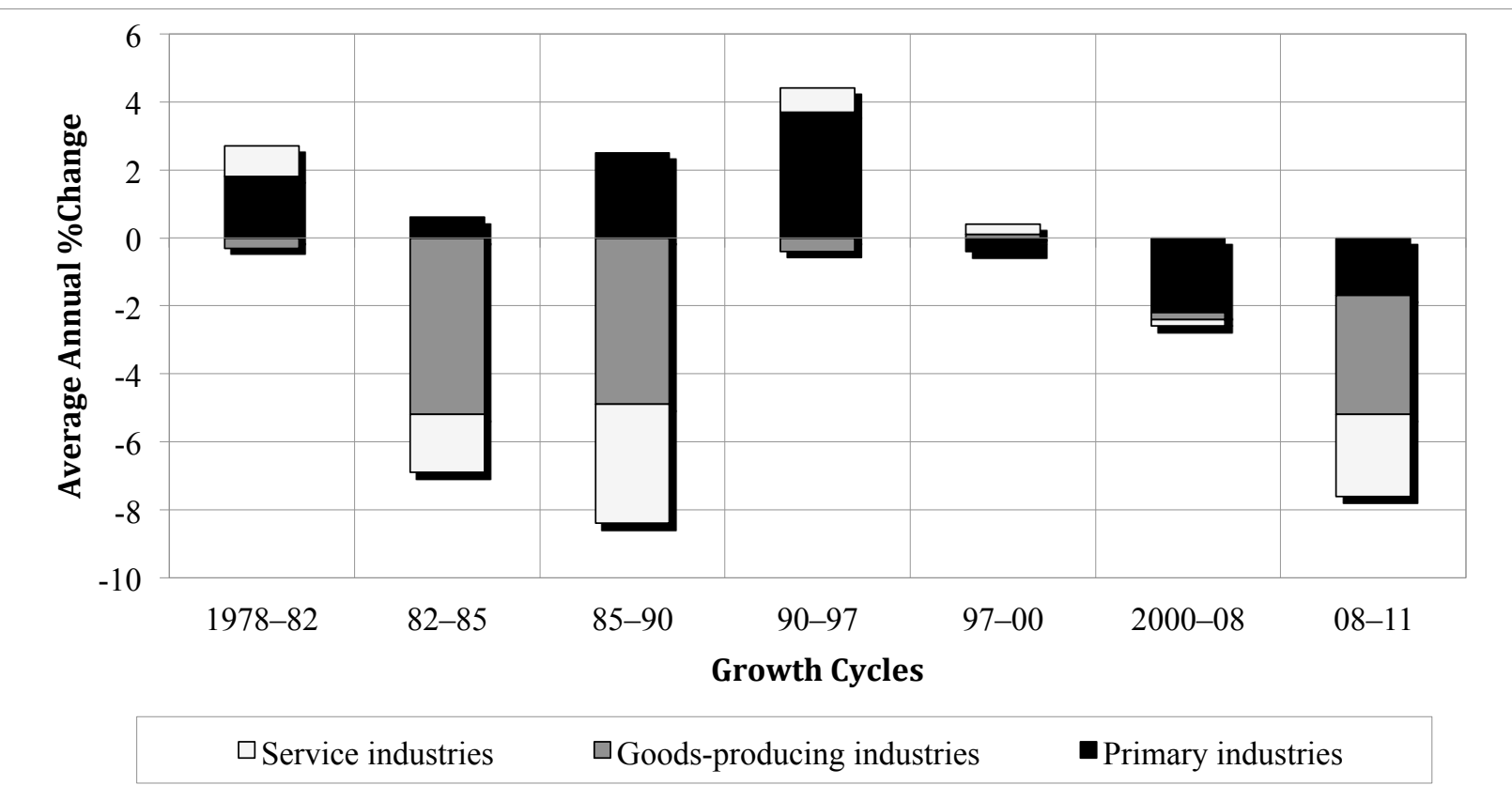

Figure 10 shows NZ's primary industries, goods-producing industries and service industries all faced ongoing decline in capital productivity since the 1990-97 growth cycle and have became negative since the 2000-08 growth cycle. Data Source: as in the Note to Figure 9. 
Figure 11: Multifactor Productivity by Sector, 1978-2011

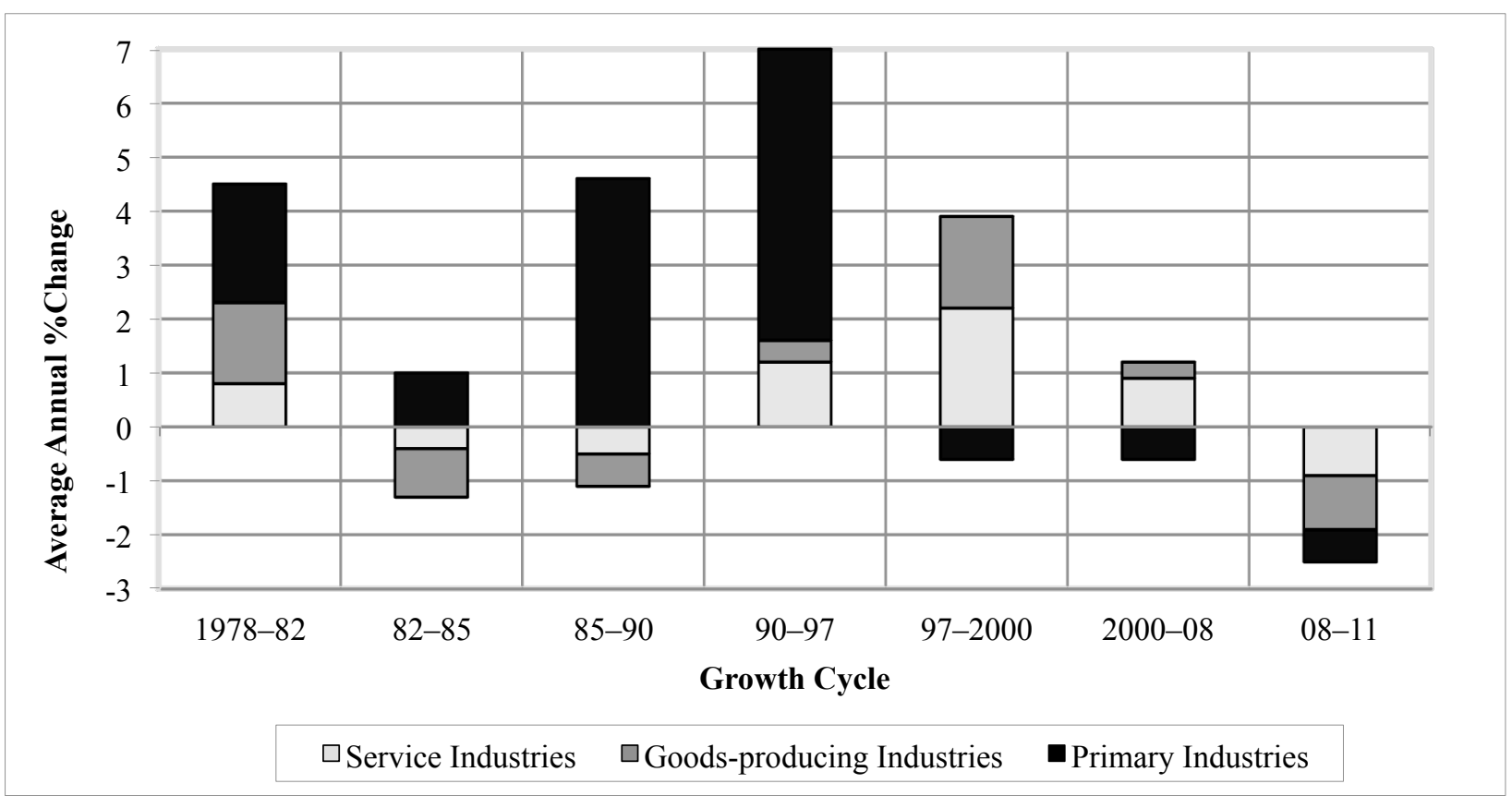

Figure 11 shows that NZ's primary industries more so than its goods-producing industries and service industries experienced larger ongoing decline in multifactor productivity (MFP) since the 1990-97 Growth Cycle. Primary industries' MFP has been negative since the 1997-2000 Growth Cycle, while the goods-producing and the service industries' annual average percentage MFP growth only became negative in the 2008-11 growth cycle. The periods are not equal because a growth cycle is the period between two peaks of output, the peak-to-peak time period. This accounts for capacity utilisation at the start and end points of a cycle when an economy's resources are most in use. Productivity is best analysed between growth cycles rather than individual years because factors such as capacity utilisation do vary from year to year, and can be high during times of strong economic growth but negative when economic activity declines. Hence, annual movements can be affected by changes in capacity utilisation rather than actual productivity change. Such a noise can be accounted for by matching years when capacity utilisation was at its peak and thus the growth cycle approach to analysing productivity change. Data Source: as in the Note to Figure 9.

Of these, NZ's capital productivity and MFP performance are of most concern. Both capital productivity and MFP average annual percentage change by growth cycles have declined significantly, from their higher positive rates to a substantially lower negative rates, between the 1990-97 growth cycle and the 2008-11 growth cycle. Statistics New Zealand (2014b) defines a growth cycle or business cycle as the period between two peaks of output (a peak to peak time period). By reflecting the points in time when resources in the economy are most in use, growth cycles take account of capacity utilisation at the start and end points of a cycle. In principle, productivity is best analysed between growth cycles because annual movements can be volatile and can be driven by changes in capacity utilisation rather than actual material productivity growth. Hence, by analysing productivity between growth cycles, and thereby matching years when capacity utilisation was at its highest, one can compare productivity growth when economic activity was at a maximum. 
An important difference between the Oh and Heshmati (2010) and Pires and Garcia (2012) studies is the implicit inclusion of the effects of the dotcom bubble burst and 9/11 terrorist attack in the former but not present in the latter. This may account for the weaker positive correlation between Technical Change (TC) and Efficiency Change (EC) in Figure 6. However, when regressed Technical Change on Efficiency Change using Pires and Garcia's (2012) data for 1970-2000 to check whether the exclusion of these effects would produce a stronger positive relationship between Technical Change and Efficiency Change, the result is only a small positive improvement. The relationship remained weak. When one also excludes Ireland and the United States (outliers) from the regression the positive relation between Technical Change and Efficiency Change improved but remained relatively weak. However, if one splits the sample into two, group one in the dashed oval and group two in the dotted oval, the positive association between Technical Change and Efficiency Change for each group is stronger (see Figure 6). Additionally, there appear to be a relative shift of the Technical ChangeEfficiency Change function between the first and the second group.

Such a pattern suggests, at least for the sample of countries examined, greater efficiency may give impetus to greater technology diffusion and innovation. Likewise, greater technological progress may generate greater absorption leading to greater efficiency. However, whether or not such causal relationships occur and how strong the effect may be can be driven by other factor(s), which dictates the extent to which an economy is exposed to external technologies on the one hand and the efficiency with which it absorbs them on the other hand. This 'other factor(s)' the paper hypothesizes to be one related to the issue of 'firm/corporate governance', specifically which of managerial competency and managerial effectiveness, which will be explored in detail later in Section 3 to 5.

\subsection{New Zealand's Productivity Under-Performance despite Its Strong Institutions}

Before the 1970s, New Zealand (NZ) was among the highest income countries in the world, with a high Gross Domestic Product (GDP) per capita in the years leading to World War II (WWII), ranking in the top 5 internationally. Though the level of productivity and ranking dropped slightly during the Great Depression in the 1930s, and WWII, it quickly recovered thereafter with accelerating productivity, placing NZ between $2^{\text {nd }}$ and $7^{\text {th }}$ place on the international ranking chart in terms of real GDP per capita between 1934 and 1960. However, the positive association between good quality institutions and economic performance seems to 
break down for NZ after the 1990s reform. NZ's institutional quality in the post reform period based on policy settings in the area of taxation, regulation, innovation and education judged by the Organisation for Economic Cooperation and Development (OECD) and various institutional indexes developed more recently has shown to be much higher than what it was in the past. Yet, NZ's GDP per capita and productivity performance seem to be much worse today than in the past. NZ had fallen from having ranked $7^{\text {th }}$ in 1967 to $23^{\text {rd }}$ by the 1980 s in terms of real GDP per capita (see Figure 12 below). Even after the NZ radical economics reform of the late 1980s and the early 1990s there seems to be little change to NZ's relative real GDP per capita position on the international ranking chart as measured by Angus Maddison. Figure 12 illustrates this.

\section{Figure 12: NZ's International Ranking Based on Real GDP Per Capita, 1890-2010}

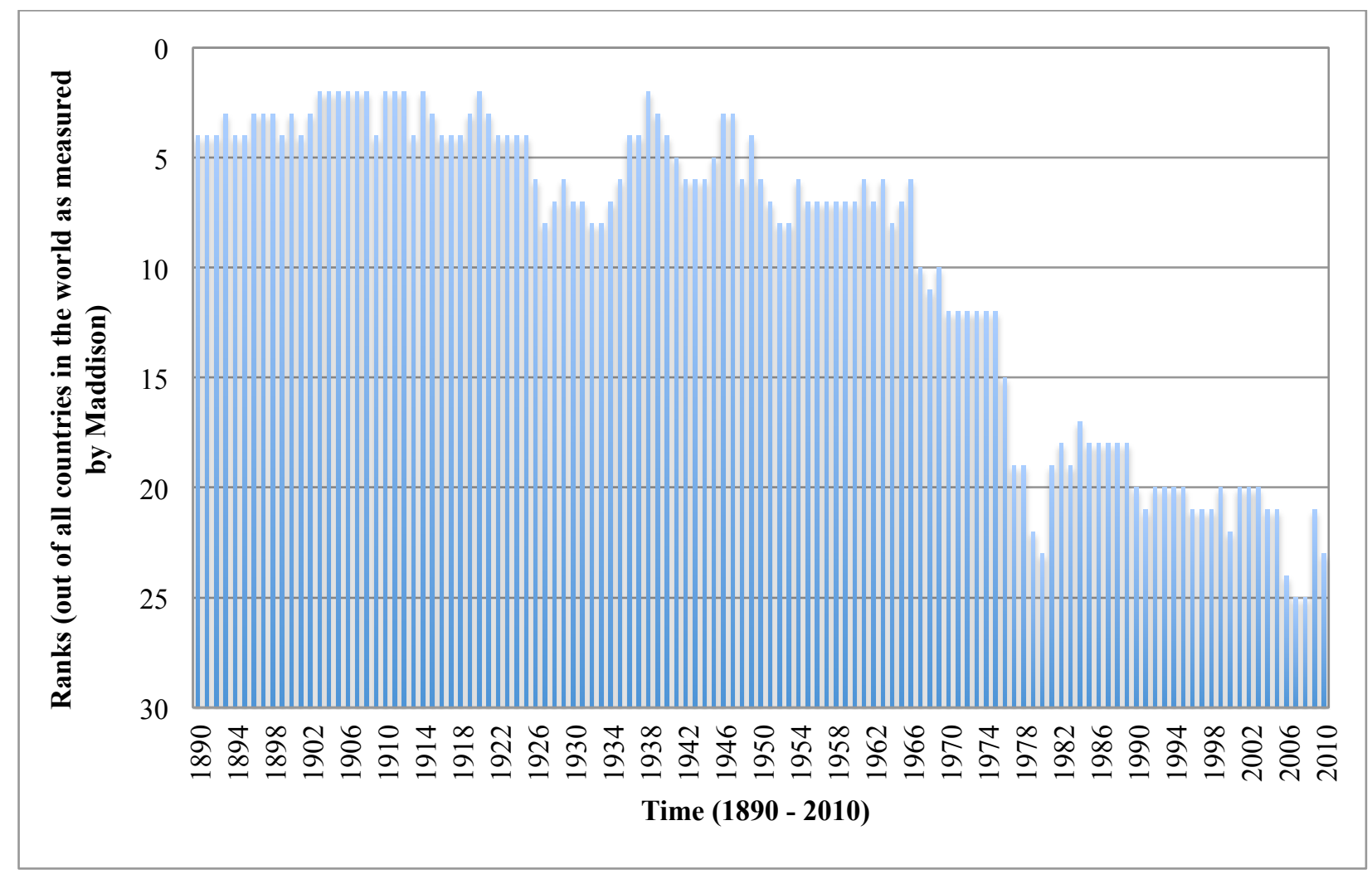

Note: Graph constructed from data made available by the University of Groningen (2004).

Figure 12 shows that the first big relative decline in GDP per capita took place in the mid-1970s and 1980s. Another relative decline occurred in the late 1980s, and since the 1990s NZ's real GDP per capita (and productivity) performance on the international ranking chart remained relatively mediocre (Mason, 2013: Investigating New Zealand-Australia Productivity Differences at Industry Level). To date, though NZ's institutional quality is of a high standard (The World Bank Group, 2013), NZ's GDP per capita, in contrast, is much lower and 
significantly lags behind its OECD counterparts (as illustrated in Figure 1 to 4), with NZ ranking at the bottom end of the OECD productivity league (Agarwal et al., 2013).

It is a puzzling phenomenon that in spite of the wide-ranging and far-reaching reforms of the 1980s and 1990s NZ's GDP per capita and productivity remains significantly below the OECD average. Despite having perhaps one of the better institutions relative to its OECD counterparts today, NZ's per capita GDP growth and productivity seems to perform much worse today. According to the Institutions Climate Index, developed by the Ifo Institute in 2007 to assess institutional quality across the OECD countries and its relationship to economic growth, NZ institutional quality has greatly improved from its 1994 level. Between 1994 and 2010, the quality of institutions in NZ has greatly improved, moving from an index ranking of $18^{\text {th }}$ to $3^{\text {rd }}$ out of the OECD countries examined in the study (Rohwer, 2011). However, the same cannot be said for NZ's GDP per capita and productivity. One must, therefore, ask the question - 'why' is productivity not catching up, given NZ's good macroeconomic and structural policies and comparatively low productivity levels to begin with? In many respects such phenomenon appears to be something of a paradox (Barnes et al., 2013; OECD, 2013). For NZ, improvement in the quality of institutions after the radical reform of the 1980s and 1990s to the present time (The World Bank Group, 2013), for some reason, has not translated into improved productivity performance.

\section{New Zealand's Relative Productivity Under-Performance - The Debates}

Solving 'The New Zealand Productivity Puzzle' is not a straightforward proposition. The puzzling phenomenon of New Zealand's (NZ's) economic performance has generated spirited debates among academia and public policy experts seeking to provide an answer to this age-old paradox. Within these debates, there are broadly two schools of thought. One focuses on NZ's geographic isolation as a constraint to its economic performance. The other school of thought focuses on the adverse effect of NZ's high interest rate and our persistent overvalued real exchange rate as the constraining factor to growth in our (more productive) tradable sectors. Therefore, generating poor economic performance. However, this paper brings forward a third line of argument, explored more recently, with respect to the links between firm/corporate governance, firm performance, stock-market development and economic prosperity. 
In this case, it is maintained that New Zealand's (NZ's) small size and geographic isolation constraint its economic performance. Rather than from an institutional or free-market perspective versus interventionist arguments to explain NZ's low productivity, this line of argument maintains that from the perspective of economic geography, there is nothing puzzling about NZ's productivity (McCann, 2009). It is argued that being the most isolated of all OECD countries makes global integration more challenging (OECD, 2008). Both the endogenous growth and economic geography literatures argue that there can be positive spillovers from size and connectedness that lead to greater technological progress and thus growth (Smith, 2011). Boulhol and de Serres' (2010) study show that being small and geographically isolated could result in a lower GDP per capita by up to $10 \%$.

However, in the geographic isolation case, NZ and Australia's good policy settings and strong institutions (Barnes et al., 2013) should overcome geographic barriers (OECD, 2013). Further, there are few empirical results from the literature relevant to cross-country income comparisons in this area (Smith, 2011). More importantly, as shown earlier, before the 1970s NZ was among the highest per capita income countries in the world, with a high real GDP per capita in the years leading to the 1970s, ranking in the top 10 internationally (see Figure 12 above). Moreover, NZ's productivity for the period 1896-1960 was also increasing, as illustrated in Figure 13 below ( $\$$ GK denoted Geary-Khamis or International Dollar).

Figure 13: NZ's Productivity (Output per worker in 1990 \$GK), 1896-1960

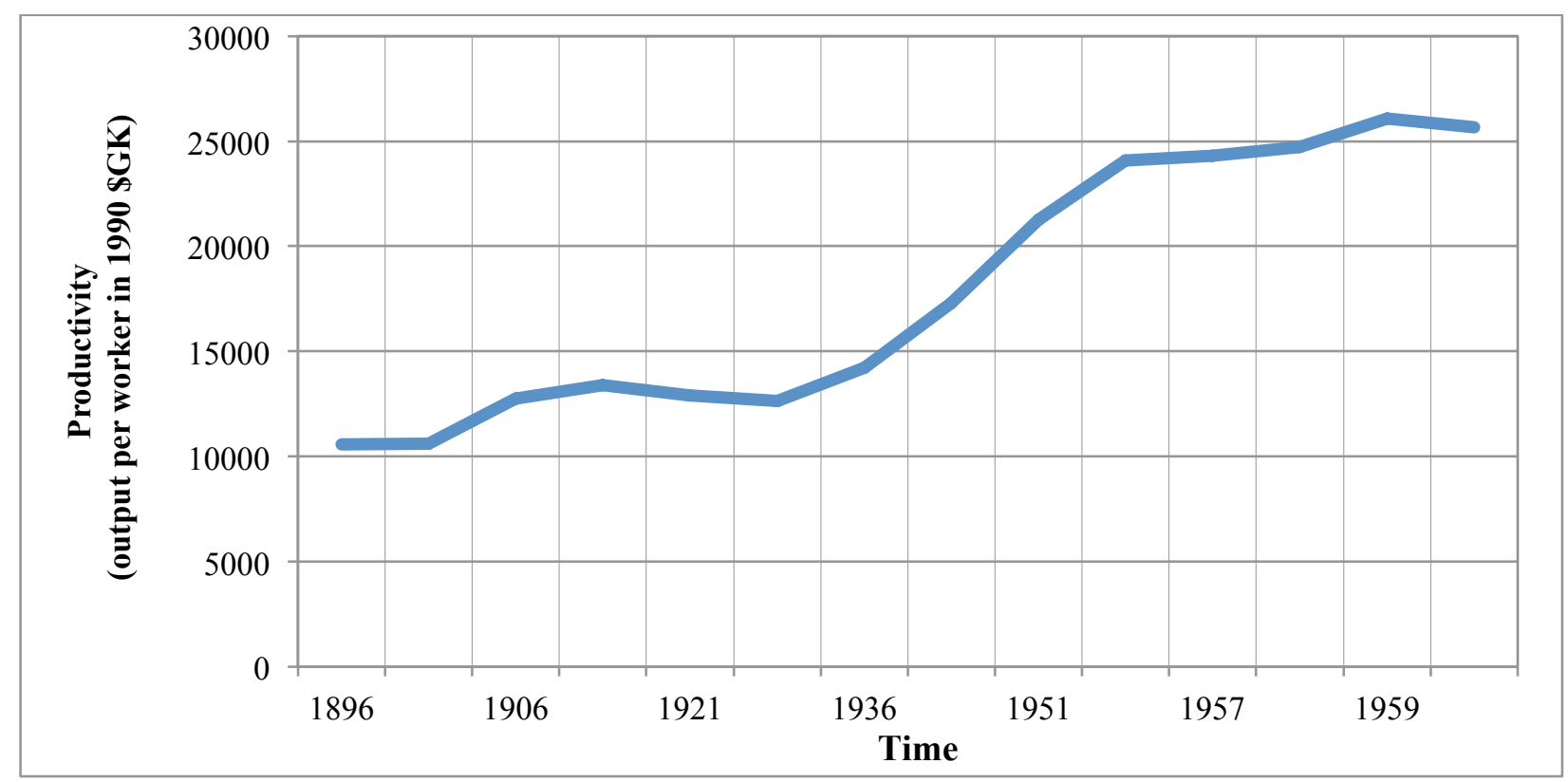

Note: Graph constructed from data made available by Long (1958) and the University of Groningen (2004). 
NZ was even smaller then and located exactly where it is now. Hence, the argument of being small and geographically isolated as factor impeding NZ's economic performance, preventing better engagement in the international market, investment in $R \& D$ and in management, simply may not hold water. This is relevant even more so today than in the past, given the advancement of technology at present, i.e. cloud computing, geographical isolation as a constraining factor to doing business becomes less and less relevant.

The National Institute of Standards and Technology defined cloud computing as a 'model for enabling ubiquitous, convenient, on-demand network access to a shared pool of configurable computing resources (e.g. networks, servers, storage, applications and services) that can be rapidly provisioned and released with minimal management effort or service provider interaction' (Mell \& Grance, 2011). In other words, instead of storing, managing and processing information using a local server or a personal computer, cloud-computing practice enables all of these to be carried out using a network of remote servers hosted on the Internet. Such internetbased computing, where large groups of remote servers are networked, allow sharing of dataprocessing tasks, centralisation of data storage, and online access to computer services or resources.

This network connection system allows employees, customers and partners to work together in a secure and reliable manner from anywhere (and anytime). Though NZ's internet infrastructure (data centres and connectivity) to date remain relatively insufficient in both its capacity and capability to enable NZ to be a global source for cloud computing resources, it does not stop NZ from using global cloud computing services to address global markets. The internetbased access to overseas cloud computing services allows NZ's businesses access to a cost based service that only a global scale can provide. Hence, at the most fundamental, macroeconomic level, such internet-based networks allow NZ's businesses to overcome the physical limitations of market size and the tyranny of distance (Kumar, 2014). At the firm level, cloud computing enables firms to reduce the costs of Information Technology benefits previously achieved via capital expenditure to mere operational costs.

\subsection{NZ's Productivity Under-Performance: An Issue of Relative High Interest Rates}

A second school of thought argues that high real interest rates since the 1990s depressed business investment and exacerbated imbalances. This helps to explain New Zealand's (NZ's) failure to close the GDP per capita and productivity gaps between NZ and other advanced 
economies. This happened at a time where higher rates of investment were required to maintain capital-labour ratios given high levels of immigration driven by policy change since the early 1990s (Smith, 2011). Further, despite the large, decades long and continuing deterioration in NZ's relative productivity, the real exchange rate on average has not decreased. The argument is that the exchange rate has not adjusted largely because average NZ real interests have remained so much above those abroad. The persistently overvalued exchange rate - itself a symptom of imbalances across the economy - can be argued to be important in understanding why, despite the far-reaching reforms of the late 1980s and early 1990s, the large gap between NZ's GDP per capita and that of those in other advanced economies has not even begun to close. This line of argument claims that had interest rates settled at around typical advanced economy levels, NZ's exchange rate would have fluctuated around a much lower average level, allowing betterbalanced, stronger and more sustainable growth in per capita incomes and productivity (Reddell, 2013).

However, in the case of high interest rates, one of the distinguishing features of open economies is that domestic investment and savings need not be equal. This means an economy can finance higher investment via running current account deficits. Hence, an important question to this argument is why cross-border financial capital mobility failed to maintain the physical capital-labour ratio at an appropriate level. Further, Kendall and $\mathrm{Ng}(2013 ;$ p. 19) show between 1992 and 2012 both NZ's and Australia's long-term interest rates behaviour had been broadly similar and high relative to interest rate in the United States, but why has only NZ's productivity trailed behind? The differences in investment rates and per capita GDP gaps in NZ, therefore, had to be due to some other non-interest factor(s) (Smith, 2011).

A non-interest factor affecting NZ's economic potential, which has quickly worked its way to the centre of academic discussion, is the influence of the fundamental changes in the global marketplace. Increasingly, one of the major problems facing many of NZ's resource based industries is that its margins have fallen and its returns have become more volatile. This is due in part to the poor profitability of the industries NZ competes in (i.e. primary production) and in part to its position in these industries (exports of raw material and not so much on value-added exports). Why? Because world trade is fundamentally changing and increasingly goodsproducing and service sectors contributed more to growth through greater value-added than the primary sector (New Zealand Productivity Commission, 2014b; Crocombe et al., 1991). 
Faced with the fundamental change in the composition of world trade (see Table 2), NZ's relatively high concentrated exports position in a few products (primary-based) in sectors with slower than average world export growth, contributed to NZ's relative poor economic performance in the post 1970s. The United Nations COMTRADE database statistics on merchandise exports as a percentage of total nominal exports, 2000 and 2008, shows that NZ's composition of merchandise exports remained heavily weighted toward food and beverage exports, relative to the comparator OECD countries (MED, 2011). Additionally, according to the 'export drivers matrix' constructed by Coriolis (2010a), the major share of NZ's food and beverage exports remained in the dairy sector. NZ produced more milk than consumed - a small economy with a small population but many cows (see graph on page 9 in Coriolis, 2010a). In fact, the dairy sector, to date, remains the main driver behind NZ's export growth, followed by meat, timber and oil (see graph on page 14 in Coriolis, 2010a). Dairy and meat together account for about 70\% of NZ's food and beverage export value (see graph on page 15 in Coriolis, 2012). This indicates that NZ's exports are still dominated by a handful of key traditional primary industries (except oil ${ }^{22}$ - rapidly emerging in the recent decade).

Table 2: NZ's GDP - Composition, by Sector (as \% of GDP)

\begin{tabular}{|l|c|c|c|c|}
\hline & $\mathbf{1 9 5 3}$ & $\mathbf{1 9 6 0}$ & $\mathbf{1 9 8 2}$ & $\mathbf{2 0 0 6}$ \\
\hline Primary & 26 & 21 & 11 & 7 \\
\hline Agriculture & 24 & 19 & 9 & 4 \\
\hline Non-Agriculture & 2 & 2 & 2 & 3 \\
\hline Secondary & 22 & 22 & 24 & 5 \\
\hline Food & 3 & 6 & 5 & 11 \\
\hline Non-Food & 19 & 16 & 65 & 77 \\
\hline Tertiary & 52 & 57 & 18 & 30 \\
\hline Other Services & 13 & 13 & 19 & 5 \\
\hline
\end{tabular}

Source: Table 2 constructed from data made available by Claus, Lattimore, Le and Stroombergen (2011). Note: More recent figures estimated for 2013 for NZ can be obtained from Central Intelligence Agency World Factbook (2012). The estimates for NZ in 2013: agriculture (5\%), industry (25.5\%) and services (69.5\%).

This is not to say that specialisation in primary commodities necessarily means lower growth. Other countries (Scandinavian countries - Norway, Demark and Sweden) also focusing on agricultural and similar such sectors are much wealthier in terms of per capita GDP than NZ. Why? Much more of value-added focus, and thus what at issue for NZ is not what we got but what we do with what we got. Saunders \& Dalziel (2014; also Saunders et al., 2011) speak explicitly about this issue. These authors maintain that to grow our wellbeing NZ needs to

\footnotetext{
${ }^{22}$ The oil industry in this recent decade experienced rapid growth following the oil discovery at the Taranaki basin and with NZ's 17 other basins in the process of exploration. This industry holds great future growth potential for NZ.
} 
concentrate on high value-added of agricultural products and hence obtain from its export markets a premium for what it is good at. Though NZ's small domestic market size may mean that firms have to export earlier in their lifecycle than is typical done overseas and NZ's distance from markets can make market positioning more difficult, good collaboration and joint ventures can help NZ overcoming these challenges.

Collaboration (or alliance) and joint ventures can improve the competitive position of the partners and develop a business in a way or to an extent or at a speed that is not achievable by the partners separately. Alliance and joint ventures can minimise the risk of entry into a new market or developing an existing market further, achieving minimum size for operating in a market and overcoming legal constraints on operating in certain countries (Park, 2014). All of these can help to enhance both the market size and the competitive position of NZ's businesses. Moreover, high research and development (R\&D) and hence innovation can further increase value-added products and better position NZ's existing exports in overseas markets. However, it appears NZ is not performing so well on these leverage points with headlines like 'low innovation and weak international connections limit productivity' (Scoop, 2014) and with The Global Innovation Index 2014 indicating NZ's relative low performance on 'joint venture/strategic alliance deals' (score 26.6 out of 100) compare to Singapore (68.3/100) and Hong Kong $(70.2 / 100)^{23}$.

Another factor affecting growth and productivity worth considering is the weakening of inter-industry linkages between NZ's manufacturing sector and the agriculture sector since 1982. Claus, Lattimore, Le and Stroombergen (2011) use the input-output tables constructed by Statistics NZ available from 1953 and the Leontief $(1936)^{24}$ and Ghosh $(1958)^{25}$ models to examine the changes in NZ's production structure. In so doing, their study reveals that since about 1982 the primary processing backward linkage and agriculture forward linkage had weakened relative to that of 1953 and 1960. Table 3 on the next page reports the results of Claus, Lattimore, Le and Stroombergen's (2011) study on NZ's 1953-2006 Structural Indicators.

\footnotetext{
${ }^{23} \mathrm{https}: / /$ www.globalinnovationindex.org/content.aspx?page=data-analysis

${ }^{24}$ The Leontief Model is given by $x=[1-A]^{-1} f$, where $\mathrm{x}$ is a (Nx1) vector of industries' gross output (both intermediate and final demand), $\mathrm{N}=$ number of industries', $\mathrm{f}$ is a (Nx1) vector of industries' final demand, I (identity) $=(\mathrm{NxN})$ and $A=\left[a_{i j}\right]$ is a $(\mathrm{NxN})$ matrix of technical coefficients. The matrix $[1-A]^{-1}$ is the Leontief inverse or total requirement matrix, showing how much output is required directly and indirectly from each industry for every dollar's worth of output produced for final use - its elements are denoted by $b_{i j}$.

${ }^{25}$ Ghosh's Inter-industry Model is given by $x^{\prime}=p[I-\tilde{A}]^{-1}$, where $\mathrm{p}$ is a $(1 \mathrm{xN})$ vector of industries' primary inputs, $\tilde{A}=\left[\widetilde{\widetilde{a}_{l j}}\right]$ is a $(\mathrm{NxN})$ matrix of direct sales coefficients with is the Ghosh inverse - its elements are denoted by $\widetilde{b_{l j}}-$ measures the output of industries that is necessary to absorb primary inputs.
} 
Table 3: 1953-2006 Structural Indicators

\begin{tabular}{|c|c|c|c|c|c|c|c|c|c|c|}
\hline & \multicolumn{2}{|c|}{1953} & \multicolumn{2}{|c|}{1960} & \multicolumn{2}{|c|}{1982} & \multicolumn{2}{|c|}{1987} & \multicolumn{2}{|c|}{2006} \\
\hline & $\begin{array}{l}\text { Backward } \\
\text { Linkage } \\
\text { ("BL") }\end{array}$ & $\begin{array}{l}\text { Forward } \\
\text { Linkage } \\
\text { ("FL") }\end{array}$ & BL & FL & BL & FL & BL & FL & BL & FL \\
\hline Agriculture/Farming & 5 & 3 & 5 & 1 & 9 & 5 & 10 & 11 & 11 & 11 \\
\hline Fishing \& Hunting & 11 & 12 & 19 & 21 & 18 & 20 & 19 & 17 & 20 & 12 \\
\hline Forestry \& logging & 12 & & 21 & 10 & 16 & 18 & 15 & 19 & 17 & 15 \\
\hline Mining & 10 & & 20 & 12 & 21 & 9 & 20 & 9 & 18 & 14 \\
\hline $\begin{array}{l}\text { Primary Processing (Food, } \\
\text { beverages, Tabacco) }\end{array}$ & 1 & 11 & 1 & 17 & 1 & 15 & 3 & 16 & 3 & 18 \\
\hline Textiles, apparel \& leather & N/A & N/A & 6 & 19 & 6 & 19 & 7 & 20 & 15 & 20 \\
\hline Wood \& wood products & $\mathrm{N} / \mathrm{A}$ & N/A & 12 & 11 & 13 & 16 & 13 & 15 & 14 & 16 \\
\hline $\begin{array}{l}\text { Paper, products and } \\
\text { printing }\end{array}$ & $\mathrm{N} / \mathrm{A}$ & N/A & 13 & 6 & 12 & 11 & 12 & 4 & 13 & 5 \\
\hline $\begin{array}{l}\text { Chemicals, petrol, rubber } \\
\text { etc. }\end{array}$ & N/A & N/A & 14 & 3 & 10 & 6 & 11 & 8 & 9 & 10 \\
\hline $\begin{array}{l}\text { Non-metallic mineral } \\
\text { products }\end{array}$ & N/A & N/A & 18 & 9 & 20 & 12 & 21 & 12 & 21 & 9 \\
\hline Basic metals & N/A & $\mathrm{N} / \mathrm{A}$ & 15 & 14 & 15 & 13 & 16 & 14 & 16 & 17 \\
\hline Fabricated metal products & $\mathrm{N} / \mathrm{A}$ & N/A & 8 & 7 & 5 & 4 & 6 & 7 & 19 & 13 \\
\hline $\begin{array}{l}\text { Other manufacturing } \\
\text { (include: electrical, } \\
\text { vehicle and transport } \\
\text { products) }\end{array}$ & 2 & 1 & 17 & 20 & 19 & 17 & 18 & 18 & 7 & 19 \\
\hline Electricity, gas, water & 9 & 10 & 11 & 13 & 14 & 7 & 14 & 10 & 10 & 6 \\
\hline Construction & 6 & 7 & 2 & 8 & 4 & 14 & 4 & 13 & 4 & 8 \\
\hline Trade, restaurants, hotels & N/A & $\mathrm{N} / \mathrm{A}$ & 3 & 2 & 3 & 2 & 2 & 3 & 2 & 3 \\
\hline Transport and storage & 7 & 5 & 9 & 4 & 7 & 10 & 9 & 5 & 8 & 7 \\
\hline Communication & N/A & N/A & 16 & 15 & 17 & 8 & 17 & 6 & 12 & 4 \\
\hline Finance, insurance etc. & 8 & 9 & 10 & 16 & 11 & 1 & 8 & 1 & 6 & 2 \\
\hline $\begin{array}{l}\text { Owner-occupied } \\
\text { dwellings }\end{array}$ & N/A & N/A & 7 & 18 & 8 & 21 & 5 & 21 & 5 & 21 \\
\hline Other services & 4 & 6 & 4 & 5 & 2 & 3 & 1 & 2 & 1 & 1 \\
\hline
\end{tabular}

Source: Table constructed based on data made available by Claus, Lattimore, Le and Stroombergen (2011).

Claus, Lattimore, Le and Stroombergen's (2011) results reported in Table 3 inform us that since approximately 1982 the primary processing backward linkage and agriculture forward linkage have weakened relative to that of 1953 and 1960. The indicator values in Table 3 ranked from one downwards on the estimated coefficient, with ' 1 ' being the strongest. Table 3 highlights that in 2006, if anything, the strength of forward linkage (FL) and backward linkage (BL) have weakened for NZ's agriculture/farming and primary processing manufacturing, with the estimated coefficient fallen from 1,1 (FL, BL) in 1960 to 3,18 in 2006 (Claus, Lattimore, Le \& Stroombergen, 2011). Hirshman (1958) and Altman (2003; 2005) also point out the significance of such linkages on economic growth and development. These authors maintain that by way of primary sector's complex linkages with the rest of the economy, the productivity spillover and spread effects which primary exports generate, can contribute directly to the growth process of other sectors, and thus to the economy as a whole. Hence, even if primary 
exports eventually constitute a small percentage of GDP, this does not mean that the sector has become less significant given its inter-industry connectedness with the rest of the economy. Rather, it would be more a case that the other internal factors have taken over "the driver's seat in directing the process of economic change" (Altman, 2003, p. 237).

In contrast, backward and forward linkages in the service sector have gathered more momentum over recent years, moving from being moderate to strong. The outstanding performer is the 'other services' industries, moving from moderately strong inter-industry linkage to very strong and achieving the estimated coefficient of 1,1 by 2006 . Given firms increased spending on services, deepening linkages of the service sector with the rest of the economy should not come as a surprise. According to the New Zealand Productivity Commission's (2014b) report, firms now on average spend about $40 \%$ more on services than they do on wages and that services cover $50 \%$ of the value of NZ's exports when the value of services (transport and finance) embedded in goods exports are included.

In sum, NZ's relatively low capital to labour ratio and its relative poor position in the value chain of the industries it competes in (exports of agricultural raw material and not so much on value-added exports - weakening of NZ's inter-industry linkages ${ }^{26}$ ) when world trade is fundamentally changing explained why NZ's economic performance is not up to the standard it once achieved in the pre-1970s. However, one would expect improvement in institutional and policy regimes at the international and national levels after the 1980s and 1990s radical reform to have helped NZ overcome these challenges. One would expect being more open and less regulated to have facilitated faster and greater trade flows, induced greater investment in innovation and in management, and thus the development of NZ's industries leading to stronger inter-industry linkages. However, the symptoms experienced in NZ are to the contrary. According to the New Zealand Productivity Commission's (2014a) report NZ's international connections are weak and its innovation and managerial quality are low. Hall and Scobie (2005) and the Treasury (2008a) report NZ's equity market as being relatively underdeveloped and capital shallow. Coriolis (2012, p. 15) report NZ's exports are still dominated by a handful of key traditional primary industries, whose structures are changing. Change is not bad per-se, the issue is how it is changing - the changing face of NZ's agriculture at the start of the second decade of the $21^{\text {st }}$ century is one of 'deepening corporate consolidation' (Small, 2013).

\footnotetext{
${ }^{26}$ See the important of linkages in Hirschman, 1958; North, 1959; Altman, 2005.
} 
Indeed, the trend towards larger dominant firms through mergers and acquisitions is a common phenomenon occurring internationally not just within NZ as countries are moving to greater deregulation (Dana \& Schoeman, 2010). Greater trade liberalisation induces greater competition in the global market, making the formation of larger firms through mergers and acquisitions an important strategic choice for securing firms' and industries' international competitiveness (Gupta, 2012). For instance, in the case of dairy in NZ, the argument is that the formation of large mega co-operatives representing a vast proportion of the nation's producers of specific agricultural commodities would ensure greater efficiencies and economies of scale necessary to secure the international competitiveness of the industry.

However, the employment of such a supposedly efficient structure in NZ, over a decade onward, has not translated into improved economic growth and productivity for NZ. If anything, the result is the contrary. Although NZ's larger co-operatives, like dairy processor Fonterra, have moved the furthest in term of its efforts in achieving cost leadership in milk production and processing, the same cannot be said for NZ's on-farm production costs. Despite the fact that the formation of 'mega dairy' has enabled NZ's processing plants to achieve greater volume and efficiency, NZ's on-farm production costs are increasing. Evidently, NZ's on-farm production costs have been rising much faster than a number of NZ's pastoral-based competitors (see graph on page 10 in Coriolis, 2010a). This indicates that NZ is loosing its comparative advantage in milk production.

By international comparison, evidence show NZ's large firms are performing poorly and that $\mathrm{NZ}$ also lacks in the relative total numbers of large firms that can be found in a number of other OECD countries (Treasury, 2008b). Hence, one must ask why large firms in NZ are performing poorly, despite the seemingly higher capacities enabled by the formation of a larger firm with greater pools of resources? Is it because of: (A) NZ's lack of managerial competencies to manage such larger firms? It was suggested that the size and international operation of the larger new co-operative structures required new and unique skills and management competencies (Dana \& Schoeman, 2010). The level of competencies in which the NZ's present managerial system may be lacking. And/or (B) had the process of consolidation simply gone too far for NZ? Although consolidation in itself may be a worldwide phenomenon, occurring alongside a highly concentrated firm ownership structure, consolidation may come at significant costs to managerial effectiveness, and thus firm performance and productivity. 
Rationalisation for operation efficiency through consolidation in itself led to the formation of dominant firms. For instance, under the mega co-operative structure Fonterra effectively holds monopoly control of the dairy industry. Alliance-Silver Fern Farms would hold a similar dominant position if the proposed mega meat merger was successful (New Zealand Herald, 2008). On the other hand, NZ's highly concentrated firm ownership structure means that NZ's firms are either one of managerial control (i.e. owner-manager in small businesses) or majority control (i.e. high percentage of dominant stockownership in publicly listed firms). The mix of dominant control of the firm and dominant control of the domestic market created a business environment in which managers are relatively free from both internal and external pressure to deliver on performance. The internal pressures on managerial performance have to do with shareholder-managers monitoring relations, whereas the external pressures have to do with the degree of competition within the domestic market. This paper argues that the absence (or lack) of these pressures on management provide a conducive environment for managerial entrenchment (Stulz, 1988; McConnell \& Servaes, 1990; 1995; Leach \& Leahy, 1991; Holderness et al., 1999; Jiang et al., 2009 have provided evidence for this). The subsequent costs to the economy that follow may be reflected in low levels of innovation and productivity improvements and a general cost-plus attitude (cf. a largely predictable state for a dominant firm or monopoly operating in a mature market).

Consequently, the issue of NZ's relative productivity under-performance despite its strong institutions may not be paradoxical but an issue of firm/corporate governance. Contrary to the argument that NZ's productivity under-performance as an issue of relative geographic isolation or that of relative high interest rates, this paper develops an explanation of NZ's productivity under-performance as a product of NZ's issue(s) of firm/corporate governance ${ }^{27}$. The focus is on the issue(s) that inherently impede NZ's principle of good firm governance from translating into good firm performance. Subsequently, the paper will be argue that a coherent understanding of NZ's productivity under-performance can be gained by examining the missing links between firm governance and firm performance, their effect on stock market development, and thus on growth and productivity. Understanding the mechanisms behind such a process would point us in the right direction to uncover the truth of 'what went wrong' for NZ to cause such a transition, from being one of the top performers to trailing behind to the extent that it is today.

\footnotetext{
${ }^{27}$ The term firm and corporate will be used interchangeably in this paper.
} 
Previously, some work in this area has attempted to provide evidence for how the issues of firm governance in New Zealand (NZ) explain NZ's firm under-performance, equity market underdevelopment, and thus poor economic performance (Healy, 2003; Frances, 2004; Xiaochuan, 2004; Kleinschmidt, 2007; Haque et al., 2012; OECD, 2012). While others explicitly examine NZ's equity market underdevelopment and capital shallowness as a factor that impedes economic growth and productivity in NZ (Helpman \& Krugman, 1985; Romer, 1990; Castalia Strategic Advisors, 2003; Hall \& Scobie, 2005; Mason \& Osborne, 2007; Capital Market Development Taskforce, 2009; NZIER, 2014). The rest of this paper aims to connect these points to provide a coherent story explaining NZ's productivity paradox. Hence, this paper argues that understanding the issues behind NZ's firm governance, its effects on firm performance, stock market development and productivity could provide us with the key to unlocking 'The New Zealand Productivity Puzzle'.

It should be noted that while economic policy is a key determinant of economic growth, so too is firm performance. It was recognised that 'the competitiveness of nations has depended in an important way upon the organisational and financial capabilities of firms and their supporting institutions' (Teece, 1993). McKinsey and Company (1997) also provided evidence for the existence of a virtuous cycle shareholder value with overall macroeconomic performance. Furthermore, they showed that a focus on shareholder value is second only to open and competitive product markets in accounting for high productivity growth. The ability of firms to create and grow its value through innovation-driven strategy, generating improvement in the productivity of the capital employed, means that the stock markets will ultimately reward its shareholders with a higher market value (Healy, 2003). The 'Shareholder Theory' provides the basis for this rationale. The shareholder theory emerges from an economic perspective focusing on the firm's purpose of maximising shareholders' wealth (Pfarrer, 2007). The ideas shaping shareholder theory emulates from Adam Smith's (1776) The Wealth of Nations. More than 200 years ago Adam Smith had postulated that:

"The most productive and innovative companies would create the highest returns to shareholders and attract better workers, who would be more productive and increase returns - a virtuous cycle. On the other hand, companies that destroy value would create a vicious cycle and eventually wither away." 
Hence, theoretically, the main purpose of business should be about generating profits and increasing shareholder wealth. Shareholders, in this sense, expect management to generate value over and above the cost of resources consumed, including the cost of using capitals. This means if management performs their functions well, increasing firm performance and profitability, shareholders would receive higher returns on their investment. If the returns on their investments are greater than the expected rate of return necessary to compensate for the risk they are undertaking, shareholders will not withdraw their capital. Additionally, the higher returns on their investments may even induce investors to invest more capital. However, if shareholders do not receive a fair return on their investment to compensate for the risk they are undertaking, they will withdraw their capital in search of better returns.

Consequently, a firm that is enhancing value will always attract further capital to finance expansion, since its good performance means that it will be benefit by a share price that stands at a premium to the underlying value of its assets and by lower interest rates on debt. On the other hand, a firm that is destroying value will always struggle to attract further capital to finance expansion, since its poor performance means that it will be hamstrung by a share price that stands at a discount to the underlying value of its assets and by higher interest rates on debt. In sum, these suggest that the association between firm/corporate governance and equity returns is a positive one (Healy, 2003; Gompers et al., 2003).

Evidently, a study by Gompers et al. (2003) of 1500 companies found a striking relationship between corporate governance and equity returns. Using an index of 24 difference provisions to build a 'Governance Index' and regressing this over firm value, they found a strong positive correlation between the Governance Index and firm value. They concluded: 'firms with weaker shareholder rights were valued lower and were associated with lower profits, lower sales growth, higher capital expenditure and a higher level of corporate acquisitions'. A previous study of 47 countries also found a strong correlation between the size and liquidity of stock exchanges and economic growth (Levine \& Zervos, 1998). Healy (2003) explained that higher share prices make consumers feel wealthier, encouraging them to spend and save more. Likewise, highly valued equity makes firms appear healthier and the firms' equity owners feel wealthier, giving them the confidence and the ability to expand production and explore growth opportunities. This is because a highly valued equity signals high firm performance making investment more attractive to potential (and existing) investors looking for better returns. Additionally, because creditors, typically, based lending criteria on the credibility of the firms, a track record of good 
firm performance also help to reduce the costs of borrowing. The combination of better access to capital and lower costs of borrowing would make expansion and investment in innovation for further growth and development an attractive economic proposition for the firms.

Increasingly international bodies have come to recognise the important role in which the stock market plays in the competitiveness of nations (Garelli, 2001). Unlike before, increasing globalisation and ever increasing international competition means that today stock markets are no longer just a mirror reflecting the performance expectations of firms, they have become a major actor in the economy, fuelling growth by injecting capital into the economy, or triggering a slowdown by depriving the economy of equity (Healy, 2003; Treasury, 2008a). Hence, in a world of global capital markets and for an economy in which foreign investment may hold the key to further growth and development, a reputation for good managerial practice and managerial effectiveness along with policies protecting shareholders can make a difference in attracting international capital and in reducing the cost of capital. Studies examining corporate NZ revealed that there are fundamental issues related to the structure of firm governance and managerial performance in some companies. They suggested that where there are serious weaknesses they have been a major cause of poor firm profitability and productivity that NZ has experienced (Healy, 2003; World Management Survey, 2010; Chartered Secretaries New Zealand Inc., 2011; Fauzi \& Locke, 2012; New Zealand Productivity Commission, 2013).

After all, organisations as an entity do not succeed or fail, the individuals who lead and manage them do. Nobel-Prize-winning economist Professor Joseph Stiglitz makes an explicit statement on this point:

"Those who manage large corporations control enormous amounts of capital. If they perform their function well, the economy and the shareholders of the firms will prosper. If they do not perform their functions well, or if they divert the resources of the firms to their own personal use, both the economy and the shareholders will suffer."

(Stiglitz, 1985, p. 133-134)

Hence, how well management function matter to firm performance and shareholders' wealth. Evidence shows that over the long term, the most important drivers of stock price performance are the strategic and operational decisions of management and the extent to which those actions generate higher firm value (Healy, 2003). This indicates that management's behaviour does matter and that their decisions do strongly influence the performance of their businesses. 
Though it is commonly agreed that there is a need for managerial development in $\mathrm{NZ}^{28}$, some authors (Healy, 2003; OECD, 2012) argued that the issue of NZ's firm governance is not necessarily a matter of managerial incompetence per-se or poor corporate governance in a conventional manner. Generally speaking, NZ firms do not suffer from the concerns that are typically subject of criticism by those promoting good corporate governance. In fact, with respect to governance practices, NZ ranked highly in the 2010-2011 Global Competitiveness Report $^{29}$. Some key results are as follows. On the ground of 'efficacy of corporate boards', NZ ranked eighth out of 139 countries. On the strength of financial and auditing standards, NZ scored third overall ${ }^{30}$. Furthermore, NZ received the fifth highest ranking for protection of minority interests and scored highest for strength of investor protection amongst 189 countries (Fox et al., 2012; The World Bank Group, 2014).

Moreover, according to Governance Metrics International, NZ was ranked fifth in the world for corporate governance (Fox et al., 2012). The issue here is not one of compliance, rather it is a question of why good firm governance with respect to compliance, at least as measured in such indexes, is not translate into good firm performance. In answering this question, one should note that the quality of managerial decisions depends not only on the ability of managers but also on the incentives that managers have to make effective choices to efficiently manage the resources under their stewardship.

In this sense, the paper argues that NZ's firm governance impedes the performance of NZ firms, may be two-fold. The first is related to the issue of managerial competency, the ability of managers to manage the assets and resources they have under their stewardship to create value for shareholders. The second is related to the issue of managerial effectiveness, the incentives for managers to efficiently manage the firm's assets and resources such that the firm's value or value-added may be maximised. The ultimate goal of any management team should be to maximise firm value. If so, then the differences in managerial ability would account for the divergence of performance across firms and countries. However, in practice managers are driven by other goals, not simply the pursuit for profits, and thus the divergence of performance across

\footnotetext{
${ }^{28}$ Business surveys conducted in 2007 and 2008 concluded that the most significant factor that hampered innovation activities in NZ firms was the lack of appropriately skilled management resources (World Management Survey, 2010).

${ }^{29}$ World Economic Forum, 'The Global Competitiveness Report 2010-2011', http://www3.weforum.org/docs/WEF_GlobalCompetitivenessReport_2010-11.pdf

${ }^{30}$ Score 6.2 out of 7 , whereby a rating of 7 indicated that investors and boards exert strong supervision of management decisions (See World Economic Forum, supra note 30, at 384).
} 
firms and countries would be driven by the managerial incentives other than managerial ability alone.

With respect to incentives, it has long been recognised that separation of ownership from control potentially has an adverse effect on firm performance. Beginning with the seminal work of Berle and Means (1932), which suggests that managers without significant ownership stakes in the firms they manage are likely to pursue activities that will enhance their own personal benefits at the expense of shareholders. Jensen and Meckling (1976) building on Berle and Means (1932) work propose the 'convergence of interests' hypothesis and argue that the propensity for managers to deviate from value maximisation decrease as managerial/insider stockownership increase. In other words, the cost of deviation from value maximisation is a decreasing function of managerial/insider ownership. Such an outcome is consistent with Leibenstein's (1966) X-inefficiency theory, the notion that the firm is a 'black box' within which exist different objective functions, whereby principal and agent problems can be reduced with better alignment of interests.

However, later works by Demsetz (1983) and Fama and Jensen (1983) argue that market discipline potentially ensures value-maximising behaviour at low levels of ownership, but entrenchment and thus value loss ensues at high levels of ownership. Stulz (1988) shows that entrenchment at higher levels of managerial/insider ownership reduces the probability of a takeover, and thus leave managers relatively free to exercise their discretions. More recently, Morck et al. (1998) also argue managers' ownership of equity can have both a positive and a negative effect on the value of the firm. To date, much theoretical and empirical research has attempted to understand the costs and benefits of insider ownership by examining the cross sectional relation between insider ownership and firm performance (typically proxy by Tobin's Q). This in turn had been taken as a proxy for managerial effectiveness (McConnell \& Servaes, 1995). Though the debate over the precise functional form of insider ownership and firm value/performance relationship is far from conclusive, most authors do lean more towards the existence of a non-linear relationship.

The concern over the association between ownership structure and firm performance emulates from the shareholder-based 'Agency Theory' which focuses primarily on the principal (shareholder) vs. agent (manager) relationship and how to best align the competing interests of the two parties to maximise firm value. The Agency Theory (AT) has a 'gloomy vision' of 
human interest in that it assumes human beings are opportunistic and therefore will put their interests before that of the firms' (Pfarrer, 2007). Under the assumption that humans are selfinterested, AT focuses on mechanisms to monitor manager behaviour and provide incentives to align manager interests with those of the firm's owners, with the aim to maximise shareholders' wealth.

To this end, it is likely that ownership structure of NZ firms has important implications for managerial effectiveness, and thus for firm performance. The link between private ownership and efficient resource utilisation guided by the profit maximisation constraint may be broken by a structure of ownership that reduces the incentives of corporate managers to maximise profits. Consequently, the divergence of actual performance from the predicted level based on compliance may arise largely as a consequence of inappropriate ownership structure that incentivises managerial entrenchment at the costs of firm performance. Hence, not only will management's ability affect firm performance but the incentives that exist for management to perform their functions well also have important implications for businesses success, equity market development, and thus for growth and productivity in the economy. The next two sections explore each of these two issues: (A) managerial competency and (B) managerial effectiveness in detail, providing evidence for the above arguments and estimating the extent to which they explain NZ's firm and related productivity under-performance vis-à-vis our OECD counterparts.

\section{4. (A) Managerial Competency, Firm Performance and Productivity}

In practice, a major drawback in analysing the relationship between management practices and firm, industry and economic performance, has been the lack of reliable empirical data on management practices measured in a consistent manner across both firms and countries (Bloom \& van Reenen, 2007). Other limitations include the context specificity of some management practices (Sousa \& Voss, 2008), and the focus on different aspects of management (i.e. operations - Holweg, 2007; performance - Bourne et al., 2005; talent and people - Becker \& Huselid, 1998). This has forced many researchers to rely on case studies for better inferences of managerial practices across firms and countries. A number of studies have also attempted to combine different management practices to investigate how they interact and operate in unison. However, these studies have not been validated in cross-countries contexts (Agarwal et al., 2013). 
Thanks to the development of the Management Practice Score (MPS) methodology, a survey instrument developed by Bloom and van Reenen (2007) with McKinsey \& Company, the assessment of managerial practices across firms and countries have been made simpler. Subsequently, many of the recent studies analysing the effect of managerial practices on firm performance across firms and countries have adopted MPS as the assessment criteria (World Management Survey, 2010).

\subsection{Assessing Managerial Competency Using Managerial Practice Score (MPS)}

The Management Practice Score (MPS) approach introduces a set of standard management practices, which enables the concept of good and bad management to be codified into the measurement framework, applicable to different firms and countries. MPS research involves a double-blind/double-scored methodology and an interview-based scoring grid that defines 'best practice' (score $=5$ ) and 'worst practice' (score $=1$ ) across 18 of the key management practices that appear to matter to industrial firms judged by McKinsey's expertise in working with thousands of companies across several decades (CentrePiece, 2005). An aspect of this double-blind technique is that managers are not told they are being scored or shown the scoring grid. They are only told they are being "interviewed about management practices" to which open questions are asked in the survey ${ }^{31}$. The interviewers continue with open questions focusing on actual practices and examples until they can make an accurate assessment of the firm's practices. The other aspect of the double-blind approach is that the interviewers are not told in advance anything about the firm's performance to limit preconceptions. They are only provided with a company name, phone number, and industry. Firms are selected randomly from a defined sample. In doing so, this method allows for consistent cross firm and country comparisons under all three broad areas of management - operations (monitoring), performance (target) and people (incentive) management. See Management Practices Dimension in Bloom and van Reenen (2007) and Bloom et al. (2012b) for further detail on the key management practices questions and the survey.

The combined responses to the 18 key management practice questions are scored from 1 to 5. For example, question 4: How is performance tracked? Firms score 1 if 'measures tracked do not indicate directly if overall business objectives are being met. Tracking is an ad-hoc

\footnotetext{
${ }^{31}$ Open question such as 'tell me how you monitor your production process' as opposed to closed questions such as 'do you monitor your production daily [yes/no]'.
} 
process where certain processes aren't tracked at all' ${ }^{32}$. Firm score 3 if 'most key performance indicators are tracked formally and is overseen by senior management ${ }^{33}$. Firms score 5 if 'performance is continuously tracked and communicated, both formally and informally, to all staff using a range of visual management tools ${ }^{34}$. The overall management scores are derived based on firm performance on these 18 management practice questions. The overall management scores can be separated into three broad aspect of management when one categorises the 18 management practices into operations (monitoring) management, performance (target) management and people (incentives) management (for this categorisation see Bloom et al., 2012a; 2012b).

\subsubsection{Managerial Practice Score (MPS) - Productivity Relation}

The validity of MPS has been compared directly with business performance across 17 countries and is generally positively correlated with productivity and output in settings where it has been tested (Bloom \& van Reenen, 2007; Green et al., 2011). Though rigorous arguments' regarding the magnitude of any causal effect is yet to be offered, the results thus far do indicate the high explanatory power of management practices as a determinant of national productivity. Among these McKinsey and Company's (2007), Bloom and van Reenen's (2007; 2010) and Bloom's et al. (2012a; 2012b) studies all suggested that in a cross-country ranking the ranking of countries' MPS approximate to productivity ranking. Their regression of GDP per capita on management practices across 17 countries yielding an R-squared value of 0.81 (a strong positive correlation of $\sqrt{0.81}=0.9$ ) provided evidence for this.

The finding that higher MPS is associated with better firm performance and productivity in several international settings is also consistent with the universalist conception that the adoption of more 'best management practices' is reflective of better management yielding higher performance and productivity (Agarwal et al., 2013). Across all the firms sampled in this research, a single point improvement in the MPS is equivalent to an increase in output as a $25 \%$ increase in the labour force (hours worked) or a $65 \%$ increase in invested capital (see Exhibit 4 in McKinsey \& Company, 2007, p. 5). Equivalently in terms of productivity, a one-point

\footnotetext{
${ }^{32}$ I.e. manager who tracked a range of measures when he didn't think output was sufficient. He last requested reports eight months ago, checked them for one week, and then stopped checking once output had increased again.

${ }^{33}$ I.e. a firm bar-coded every product, and performance indicators were tracked throughout the production, but this information was not communicated to workers.

${ }^{34}$ I.e. firm that had screens visible to every line displaying hourly progress to target. The manager met daily with frontline staff to discuss these and monthly with the whole company to discuss overall performance.
} 
increment in a five-point management practice score is associated with about $23 \%$ greater productivity (GDP per hour worked; see the exhibit "The Return on Good Management" in Bloom et al., 2012a). Even after controlling for a variety of factors such as the firm's country, sector and skill level, this observation holds (McKinsey \& Company, 2007).

\subsubsection{Results and Analysis}

Based on the results of three studies, Bloom and van Reenen (2010), Bloom et al. (2012b) and World Management Survey (2010), on Management Practice Score (MPS) by country, on average, the resultant MPS for NZ and our selected OECD counterparts are as reported in Table 4. Table 4 highlights NZ's relative poor ranking and position on MPS compared to our OECD counterparts in the sample.

Table 4: Average Management Practice Score (MPS) Outcomes from Three Studies

\begin{tabular}{|l|c|c|c|c|c|c|c|c|c|}
\hline Country & $\begin{array}{c}\text { Overall } \\
\text { Management }\end{array}$ & $\mathbf{R}$ & $\begin{array}{c}\text { Monitoring } \\
\text { Management }\end{array}$ & $\mathbf{R}$ & $\begin{array}{c}\text { Targets/ } \\
\text { Performance } \\
\text { Management }\end{array}$ & $\mathbf{R}$ & $\begin{array}{c}\text { Incentive/ } \\
\text { People } \\
\text { Management }\end{array}$ & $\begin{array}{c}\text { No. Firm } \\
\text { Rnterviews }\end{array}$ \\
\hline AUS & 3.01 & 6 & 3.27 & 7 & 2.99 & 7 & 2.75 & 8 & 385 \\
\hline CAN & 3.15 & 5 & 3.44 & 4 & 3.02 & 5 & 2.98 & 2 & 355 \\
\hline FRA & 3.01 & 6 & 3.32 & 6 & 2.97 & 8 & 2.74 & 9 & 403 \\
\hline GER & 3.20 & 2 & 3.46 & 3 & 3.23 & 3 & 2.93 & 3 & 437 \\
\hline GRC & 2.68 & 12 & 2.91 & 12 & 2.59 & 12 & 2.53 & 12 & 197 \\
\hline IRL & 2.83 & 11 & 2.99 & 11 & 2.75 & 11 & 2.79 & 7 & 103 \\
\hline ITA & 3.00 & 8 & 3.14 & 10 & 3.00 & 6 & 2.72 & 10 & 224 \\
\hline JPN & 3.19 & 3 & 3.37 & 5 & 3.29 & 1 & 2.89 & 4 & 184 \\
\hline SWE & 3.19 & 3 & 3.56 & 1 & 3.21 & 4 & 2.82 & 6 & 307 \\
\hline UK & 3.00 & 8 & 3.22 & 8 & 2.94 & 10 & 2.85 & 5 & 913 \\
\hline USA & 3.33 & 1 & 3.50 & 2 & 3.23 & 2 & 3.26 & 1 & 862 \\
\hline NZ & 2.93 & 10 & 3.18 & 9 & 2.96 & 9 & 2.63 & 11 & 106 \\
\hline $\begin{array}{l}\text { Sample } \\
\text { Average }\end{array}$ & 3.04 & & & & & & & & \\
\hline
\end{tabular}

Note: $\mathrm{R}$ denoted Rank. Manufacturing firm sample. Overall management is the average score across all 18 questions. See Bloom et al., 2012b for full list of questions and their descriptions. All questions are scored the same across all countries and industries. The highest to lowest scores in each column are ranked from 1 to 11 , respectively. Data Source: Bloom \& van Reenen, 2010; Bloom et al., 2012b; World Management Survey, 2010.

The results in Table 4 highlight serious concerns about NZ, with NZ's overall MPS having ranked below the sample average and ranked at the bottom of the league on 'Incentive/people Management' (slightly above Greece). The outcomes in Table 4 also reveal management styles across countries. NZ appears to use monitoring and target setting more than incentives (relative to the average). In contrast, better overall management practices and productivity performers like the United States, Japan, Sweden, Canada and Germany appear to use a combination of all three and that all of these countries are ranked in the top percentile in 
terms of the incentive management score. In order to obtain a better picture of NZ's MPS performance on the different aspects of management relative to the sampled OECD countries, the results in Table 4 are presented as boxplots in Figure 14.

Figure 14: NZ's Management Practice Score (MPS) Relative to Our OECD Counterparts

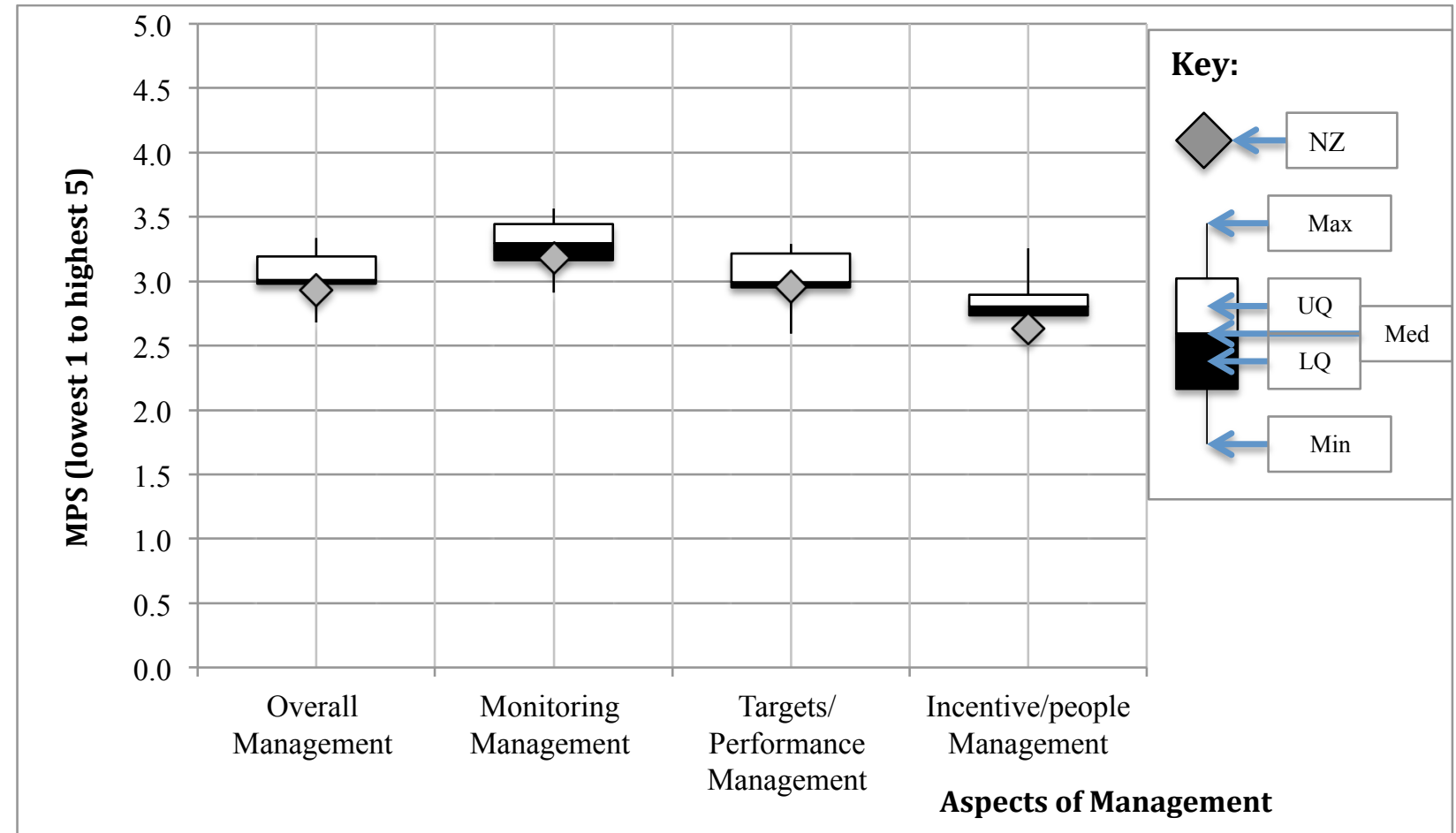

Note: New Zealand (NZ); Maximum (Max); Minimum (Min); Upper Quartile (UQ); Lower Quartile (LQ); Median (Med). Source: The graph is constructed from data in Table 4.

The boxplots in Figure 14 read as follows. The box shows the interquartile range that contains values between $25^{\text {th }}$ and $75^{\text {th }}$ percentile of the sampled countries' MPS for 'Overall', 'Monitoring', 'Target/performance' and 'Incentive/people' aspects of management. The white box denotes the upper quartile range (containing the values between $50^{\text {th }}$ and $75^{\text {th }}$ percentile). The black box denotes the lower quartile range (containing the values between $25^{\text {th }}$ and $50^{\text {th }}$ percentile). The line in between these boxes is the median. The two whiskers show the adjacent values. The upper (lower) adjacent value is the largest (smallest) observation up to a maximum (minimum) at the end of the whisker, respectively. The grey diamond denoted NZ's MPS on each of the different aspects of management examined. Overall, Figure 14 provides a graphical illustration of the points made earlier in the analysis of Table 4. In particular, NZ's relative MPS under-performance on all aspect of management (monitoring, targets and incentives) vis-à-vis the sample median of the 11 OECD countries examined for the period 2004-2010. 
The relatively small spread of these boxes, i.e. small differences in scores across countries, may be due to three factors. The first is related to the small sample size. The second is related to the sampled population. A small sample size that made up predominantly of highincome and relatively well-developed OECD countries means relative differences in competencies (education and skills) would be small. Though the spread may be larger if the sample size is larger and if developing economies are included in the sample, one must also consider the importance of scale. In this set up, a single point differences in MPS is said to be equivalent to a $23 \%$ differences in productivity. Hence, a relatively small difference in the score (of 0.1 ) does means a lot in terms of productivity difference (of $2.3 \%$ ).

Table 5: Managerial Performance and Productivity Relation - Using Spearman

\begin{tabular}{|c|c|c|c|c|c|c|c|c|}
\hline Country & $\begin{array}{c}\text { GDP per hour } \\
\text { worked (1) } \\
\text { (USD 2005 PPPs) } \\
\end{array}$ & $\begin{array}{l}\text { MPS } \\
(2) \\
\end{array}$ & $\begin{array}{c}\text { Rank } \\
(1) \\
\end{array}$ & $\begin{array}{c}\text { Rank } \\
(2) \\
\end{array}$ & $\begin{array}{l}\text { Difference } \\
\text { (1) and (2) }\end{array}$ & $\begin{array}{c}{\text { (Difference })^{2}}=d^{2} \\
\end{array}$ & $\sum d^{2}$ & $\begin{array}{l}\text { Spearman's } \\
\text { Rank } \\
\text { Correlation } \\
\text { Coefficient } \\
\end{array}$ \\
\hline AUS & 41.84 & 3.01 & 6 & 6.5 & -0.5 & 0.25 & & \\
\hline CAN & 39.76 & 3.15 & 7 & 5 & 2 & 4 & & \\
\hline FRA & 47.9 & 3.01 & 2 & 6.5 & 4 & 16 & & \\
\hline GER & 47.34 & 3.20 & 3 & 2 & 1 & 1 & & \\
\hline GRC & 29.11 & 2.68 & 10 & 11 & 1 & 1 & & \\
\hline ITA & 37.29 & 3.00 & 8 & 8.5 & -0.5 & 0.25 & & \\
\hline JPN & 34.04 & 3.19 & 9 & 3.5 & 5.5 & 30.25 & & \\
\hline SWE & 42.67 & 3.19 & 4 & 3.5 & 0.5 & 0.25 & & \\
\hline UK & 42.36 & 3.00 & 5 & 8.5 & 3 & 9 & & \\
\hline USA & 52.49 & 3.33 & 1 & 1 & 0 & 0 & & \\
\hline NZ & 28.29 & 2.93 & 11 & 10 & 1 & 1 & 63 & 0.71 \\
\hline
\end{tabular}

Note: Own calculation. *Formula used Spearman's correlation $=1-\left(\frac{6 * \sum d^{2}}{n *\left(n^{2}-1\right)}\right)$, where $\mathrm{n}=$ number of countries. Data (1) GDP per hour worked, USD, constant prices, 2005 PPPs for the period 2004-2010. Source: OECD, $2014 \mathrm{~b}$. Data (2) MPS on overall management score extracted from Table 4 above (studies' period 2004-2010).

The calculation of Spearman's rank correlation coefficient $\left(r_{s}\right)$ measuring the strength of the relationship between the sample countries productivity ranking (measured by GDP per hour worked) and their Management Practice Score (MPS) ranking verify the proposition that 'in a cross-country ranking the ranking of countries' MPS are approximates to their productivity ranking' (McKinsey \& Company, 2007). In Table 5 above, the paper shows the calculation of Spearman's rank correlation coefficient between the sample countries' productivity ranking and their MPS ranking yield a correlation result of around 0.71 . Figure 15 below provides a graphical illustration of this. 
Figure 15: GDP Per Hour Worked Rank vs. MPS Rank for 11 OECD Countries

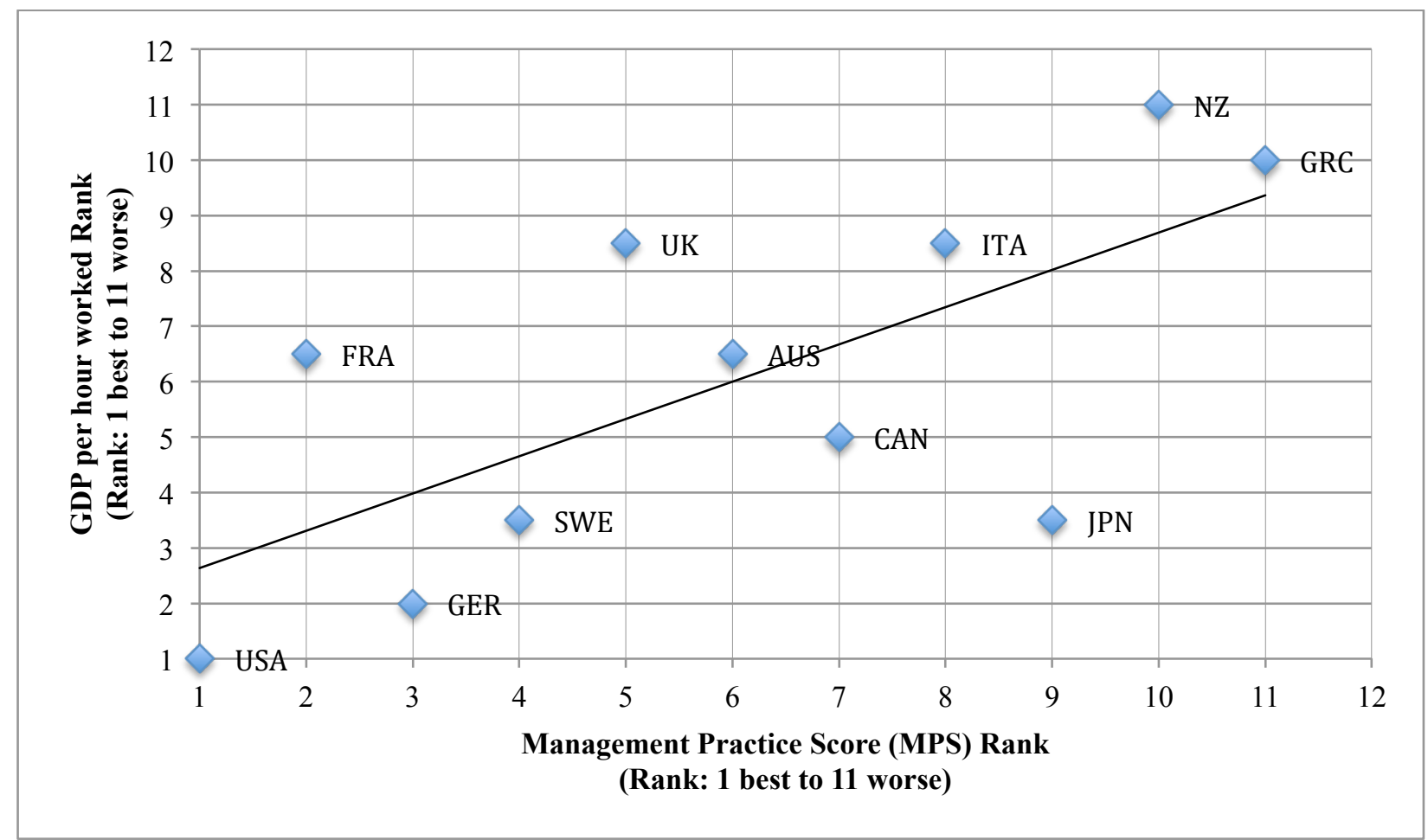

Data Source: Graph constructed from data in Table 5. Note: Sampled countries (where complete data are available) are ranked on their MPS and GDP per hour worked, from $1-11$ (best to worse). List of country's name abbreviation see Note to Figure 1 or see the list of abbreviations on page 5.

This paper uses Spearman's rank correlation instead of Pearson's correlation because the data assumption of linearity may not hold ${ }^{35}$. Differing from Pearson's correlation coefficient, Spearman's correlation coefficient is a statistical measure of the strength of monotonic relationships between paired data. Nonetheless, the way one would interpret Spearman's is similar to the way one would Pearson's. That is $-1<r_{s}<1$. Hence, the Spearman's rank correlation coefficient that yields the value of 0.71 indicates a strong positive association between countries' ranking of managerial practice score (MPS) and their productivity (GDP per hour worked) ranking. Regressing MPS vs. GDP per capita across this sample of countries for the same period yields similar result. Bloom's et al. (2012) regression result with a larger sample size shows a positive correlation of 0.9 . These findings reinforce the prior results by McKinsey \& Company (2007) and hence the assertion that in a cross-country ranking the ranking of countries' MPS approximate to productivity ranking, ${ }^{36}$.

\footnotetext{
${ }^{35}$ The relationship between paired data, GDP per hour worked and MPS, appear to be a monotonic one. Monotonic function is a function that neither entirely non-increasing nor non-decreasing (Stover, Christopher. Monotonic Function. From MathWorld-A Wolfram Web Resource, created by Eric W. Weisstein. Retrieved from http://mathworld.wolfram.com/MonotonicFunction.html).

${ }^{36}$ Like any other economic model, MPS is not without its limitations but it is the best management practice scoring methodology we have to date (McKinsey \& Company, 2007).
} 
Bloom et al., (2012a; consistent with McKinsey \& Company, 2007) interpreted that a single point improvement in MPS - an equivalent of going from the bottom third to the top third of the group - is associated with $23 \%$ greater productivity. Following this logic, a $22 \%$ of a single point improvement (i.e. going from 2.93 to 3.15) in MPS, maneuvering NZ into the top 5 position in the sample, would lead NZ's productivity to be $5 \%$ higher than otherwise would be. However, closing the MPS gap between NZ and the top 5 OECD countries, yielding an improvement of productivity and thus income of this size, is not enough to close the substantial productivity gap between NZ and the top 5 OECD countries (illustrated in Figure 4 earlier). Hence, some others factors have to be at play in impeding NZ productivity performance, and thus income growth, beyond the issue of managerial competencies alone.

\subsubsection{Considerations}

Management Practice Score (MPS) is derived from a large survey research program that's generated a systematic measurement of management practice (quality) across firms and countries. Though MPS provides a far better general measurement of management quality than the case studies based method used to judge managerial quality in the past, one must recognise the limitation of the sample size. The surveys are based on the sample of manufacturing firms for inference of overall management quality (focusing on aspects of management like systematic performance monitoring, setting appropriate targets, and providing incentives for good performance) across firms and countries. Such an approach provides a consistent measure across firms and countries. However, because the sample is restricted to manufacturing some may argue the score reflected may be in part subject to countries structural bias. That is, the US might be highly ranked in part because it is relatively more industrial than the others. Likewise NZ might be low-ranked in part because it is less industrial and more agricultural.

Nonetheless, the fact that countries' MPS ranking and their productivity ranking is strongly correlated suggests that the noise created from such a bias may be small. McKinsey \& Company (2007) when estimating the effect of a single point change in MPS on productivity change also corrected for such bias by controlling for a variety of factors such as the firm's country, sector and skill level in their estimation. They show in the estimation, after controlling for these factors, a single point improvement in MPS would account for about $23 \%$ greater productivity. Hence, the effect of an incremental change in MPS on productivity estimated is considered to be robust to countries structural bias. However, more detailed data construction for NZ, for example, across sectors would be useful. 


\section{5. (B) Managerial Effectiveness, Firm Performance and Productivity}

The ultimate goal of any management team should be to maximise the firm value, and thus generate the highest possible returns to their shareholders. However, in practice more often than not, firms may not maximise profit, not because they cannot but because they do not want to. Leibenstein $(1966 ; 1973)$ argues the traditional profit maximising theory assumes away the internal efficiency implications of business organisations (Foss \& Klein, 2005) and taking individuals' efforts as fixed at some maximum (Altman, 2004; 2013). Leibenstein maintains that the existing traditional theory with its basic economic assumption of optimal input decisions has failed to consider one important type of distortion. That is, the sort of distortion that arises from managerial inefficiency, whether because of deficient motivation or inappropriate incentives, managers are not maximising their efforts to achieve productive efficiency (McNulty, 1967). In other words, people and organisations for various reasons would not work as hard or as effectively as they could.

Leibenstein (1966) argues the actual distortion that would be generated from managerial inefficiency can be substantial because managers do not just determine their own productivity. They also determine the productivity of all co-operating units within an organisation. Leibenstein has termed this undefined distortion as X-inefficiency. X-inefficiency related to the firm not being as productive as it could be under a better set of incentives and/or preferences by management and workers. The existence of X-inefficiency, therefore, means that the improvement in X-efficiency to ensure optimal level of efforts is an important source of increased output.

In Leibenstein's X-efficiency theory (1966) social influences and norms play an important role in determining individual behaviour. In this sense, individuals' non-profit maximisation behaviour may arise because they find themselves stuck in an inert area. Leibenstein suggested that individuals might find themselves in an inert area because the utility of changing behaviour is less than the utility of maintaining one's patterns. Hence, stuck in an inert area, behaviour can be in a less than fully rational equilibrium and the firm in a less than fully $\mathrm{x}$-efficient equilibrium. To that end, though maximisation and rationality postulate are not rejected per-se, what is rejected in Leibenstein's X-efficiency theory of the firm is that they are the only form of behaviour, which is traditional profit maximising. 
This result is also echoed in Cyert and March's (1963) investigation of the actual process of making business decisions and the ways in which organisations make these decisions. Cyert and March (1963) reported on several studies in their formulations of expectation and choice processes used to develop computer models. Their results highlight the complexity of organisation and suggest that the existence of unresolved conflict is a conspicuous feature of organisations since individuals' priorities and information may vary. Hence, they argue to reconcile these conflicts in real firms, firm outcomes are a product of satisficing rather than maximising, whereby individuals settle for a good enough decision rather than striving for the best outcome. The notion of satisficing falls under the concept of bounded rationality (developed by Herbert Simon, 1955), suggesting that individual's prudent behavioural decisions are made based on their circumstances. Consequently, in such a case, it is not a question of competence, but a choice under a given situation - sometimes a lifestyle choice (Healy, 2003).

In this light we can see that unlike the behavioural approach to the theory of the firm, the firm of the conventional economic theory defines clear broad divisions to which resources may be put (consumption and production) and defined firms (households) as the theoretical institution in which rational decisions about production (consumption) take place. Demsetz (1983), following the behavioural theory of the firm, argued that such conventional economic assumptions ignore some characteristics of real firms and real households. Some household activity is devoted to production and as such is guided by profit considerations. The persons who manage real firms may also consume while on the job and as such is guided by utility consideration. Consequently, when real firms are not so specialized in their activities (consumption or production) and with compensation received by the owner-managers potentially comprising of pecuniary wages of management and profit of owners, an outcome of sub-optimal profitability need not signal incompetent management on the part of the owners. This is because the owners may be willing to carry the cost of their incompetent if other interests offset it. That is, the owner-managers who consume on the job pay for their amenities by accepting a reduction in their implicit managerial compensation ${ }^{37}$. Given their circumstance, the owner-managers are satisficing - since this is simply a substitution of profit maximising utility function for a broader utility function.

\footnotetext{
${ }^{37}$ On the job consumption only take place if the cost of doing so, per unit of utility received, is less than if he/she consumed at home.
} 
Evidence in the entrepreneurship literature, clearly suggests that entrepreneurs, a special kind of owner-managers, are motivated by both financial and non-financial considerations (see Gatewood et al., 1995; Kolvereid, 1996; Kuratko et al., 1997; Carter et al., 2003). Likewise, the family-business literature also indicates that family-owned firms tend to favour the preservation of family control, even at the expense of financial gains (Gomez-Mejia et al., 2007). Hence, it is clearly an error to suppose that a firm is profit-maximising as postulated in the conventional firm model in economic theory, whereas in reality the owner-manager of a firm is guided by utility maximisation, not simply the pursuit of profits.

Premise 1: If a wholly-owned firm is managed by the owner, he will make operating decisions that maximise his utility.

Family and small private businesses ${ }^{38}$ form the basic building block of businesses throughout the world. In New Zealand (NZ) they are the dominant form of businesses, accounting for well over $95 \%$ of all business entities and represent the greatest source of employment and a considerable source of economic growth (Healy, 2003; cf. MBIE, 2014 stated some $97 \%$ of enterprises in NZ are small businesses). Family businesses present a special challenge as both family and business relationships have to be managed and conflicting needs have to be resolved. For instance, owner-managers may find it more efficient for consumption to be carried out within the firm rather than the household - a substitution of profit maximisation (production activity) for utility maximisation (consumption activity). Such consumption may involve the use of a business account for consumption by the owners or family members, which may be more efficient because of the tax benefits and concessions on goods purchased for use in the business. However, a large part of on the job consumption is related to the owner-mangers consumption of non-pecuniary benefits (e.g. being one's own boss, having flexibility over one's hours worked) or sub-optimal risk-taking activities, whereby the owner-managers personally bear the cost of their value-reducing actions (managerial shirking or non-wealth maximising behaviour) (Hubbard \& Palia, 1995). Hurst and Pugsley's (2010) study shows a majority of small business owners report that non-pecuniary benefits were the primary reason that they started their business.

\footnotetext{
${ }^{38}$ Small businesses take many forms, including sole proprietorships, family businesses, partnership, private companies, joint ventures, and unlisted companies.
} 
The issue of profit maximisation and utility maximisation substitution goes beyond small private businesses and is evident in publicly listed firms. In publicly listed firms, as the manager's fraction of the equity falls, his/her fractional claim on the outcomes falls. This will tend to encourage him/her to appropriate large amounts of the corporate resources for his/her own personal benefits because a manager will only bears a fraction of the costs of any nonpecuniary benefits that he/her takes out in maximising his/her own utility (Jensen \& Meckling, 1976). Furthermore, manager's incentive to devote significant efforts to creative activities such as searching out new ventures also falls because he/she will only bears a fraction of the benefits from the resultant gains. Consequently, the performance of the firm would be substantially lower than might otherwise be the case.

\section{Premise 2: The costs of deviation from value maximisation decreases as insider ownership increases. 'The Convergence of Interest Hypothesis' suggested that the more stock management owns the stronger their incentives to work harder to increase firm performance, which is what shareholder wants.}

However, later studies (Fama \& Jensen, 1983; Morck et al., 1988; Stulz, 1988; McConnell \& Servaes, 1990) also point out the costs to significant managerial ownership. They argue a manager who controls a substantial fraction of the firm's equity may have enough voting power or influence more generally to guarantee his/her employment with the firm at an attractive salary. Jiang et al. (2009), using data from NZ publicly listed companies for the period 2001 to 2005, found that Chief Executive Officer (CEO) compensation is negatively (positively) associated with firm performance in firms with high (low) concentrated ownership structure, respectively. Based on their investigation of the non-linear interaction between CEO compensation, firm performance and ownership concentration, Jiang et al. (2009) suggest that when ownership concentration is higher any individual shareholder has more power and may be more likely to attempt to expropriate firm resources. This is because large management ownership may insolate management from other forces that reduce agency costs such as threat of takeovers and the discipline of the board. Additionally, large managerial ownership is often a characteristic of family-controlled firms, which have shown to be notorious for putting the interests of the family above the interests of the shareholders.

Hence, with effective control, managers may indulge their preference for non-value maximising activity in the form of high salary and empire building (Morck et al., 1988; McConnell \& Servaes, 1990; Lee \& Ryu, 2003). Wright's et al. (1996) analysis of the impact of 
corporate insider equity ownership on firm risk taking also found that financial and nonfinancial benefits or costs, at high levels of stockownership, might induce managerial decisions inconsistent with growth-orientated risk taking. They argue at high level of managerial ownership equity ownership may represent a significant proportion of a corporate managers' total wealth, and thus increasing managerial equity ownership would result in an increasingly undiversified personal wealth portfolio. The potential of an undiversified personal wealth portfolio means that managers would make decisions based solely on the evaluation of their personal costs and benefits resulted from a particular firm strategy. Such a practice may leads to the selection of a set of non-value maximising projects for a firm at the cost of growth-orientated risk taking ones, leading to lower firm performance and shareholder wealth than otherwise might be the case (Wright et al., 1996).

Premise 3: Ownership concentration at some level does not constrain excessive management power, but exacerbates agency problems associated with executive pay, perks and perquisites 'The Entrenchment Hypothesis'.

Nonetheless, a related set of literature focuses on the pressure that outside blockholders and institutional investors can induce to force the firm toward value maximisation suggests that, the expropriating activities of management could be limited (though not eliminated) by the expenditure of resources on monitoring activities by outside shareholders at a cost (Jensen \& Meckling, 1976). The price shareholders pay for shares will reflect the monitoring costs. Shareholders will find it desirable to bear the costs of monitoring as long as the welfare increment they experience from converting their claims on the firm into general purchasing power is large enough to offset them. Compared with small atomistic shareholders (dispersed ownership) holders of large blocks (i.e. institutional investors and blockholders) can exert takeover threats.

Takeover bids in a market for corporate control is where alterative management teams compete for the right to control the assets of undervalued firms (Jensen \& Ruback, 1983). This works as an effective disciplinary device for management teams who engage in opportunistic and ineffective behaviour. According to Shleifer and Vishny (1986) successful takeovers occur only when the bidder has already acquired a larger than minority ownership stake in the firm. This suggests that small atomistic (minority) shareholders cannot benefit from costly monitoring, whilst holders of large blocks can because they are able to capture the proportion of the wealth gains resulting from a successful takeover. In theory, wealth gain is assumed following the 
change in control after a successful takeover because such action is assumed to allow the acquirer to replace managers who failed to serve the shareholders' interests with managers who promise better value (Reis, 2006). Consequently, due to costly monitoring and the unlikeliness of a successful takeover, when the bidder has not acquired some significant ownership stakes in the firm, managers of firms with atomistic shareholder ownership structures are relatively free to exercise their discretion and to pursue their own interests. Subsequently, assets in this case may be deployed to benefit managers rather than shareholders. In contrast, because of the potential takeover threat that holders of large blocks can exert, a higher level of block and institutional ownership can induce effective monitoring over a firm's managerial decisions. This suggests that ownership concentration may enhance firm value (McConnell \& Servaes, 1990; Jiang, 2008).

\section{Premise 4: Dispersed ownership cannot enforce value maximisation, as monitoring activities may not be effective due to excessive monitoring costs.}

Premise 5: Outside institutional and block holders have greater expertise and resources that can monitor management at lower costs compared to small atomistic shareholders - 'The Efficient Monitoring Hypothesis': predicting a positive relationship between outside block ownership and firm performance.

Holderness and Sheehan's (1988) study compares Tobin's Q ratios (the total market value of a firm divided by the replacement costs of its assets) ${ }^{39}$ and accounting profit rates of the sample of firms in which a single shareholder owns $50 \%$ or more of the firm's outstanding common stock with those of a matching sample of firms in which no single shareholder owns more than $20 \%$ of the stock. Their study, however, revealed no significant difference between these two samples for either measure of performance. Hence, it is likely that monitoring may actually be ineffective over some regions, allowing entrenchment effect to dominate. Insofar, there are two hypotheses for this proposition, namely 'the conflict-of-interest hypothesis' and 'the strategic-alignment hypothesis'. The former predicts that due to other profitable business relationships with the firms, large block holders (controlling or majority shareholders) are effectively pressured into voting their shares with management. While the latter suggests that institutions, blockholders and managers find it mutually advantageous to work together (Maher \& Andersson, 1999). In essence, both of these hypotheses postulated that, if block holders find it advantageous to work for management instead of monitoring them, concentrated ownership

\footnotetext{
${ }^{39}$ Tobin's Q is a well-accepted proxy for firm performance and widely used in the literature of corporate governance, since it allows one to assess the value of the firm through the market's valuation of securities and can capture the long-run impacts of corporate actions (Hu \& Izumida, 2008). Tobin's Q might be vary by industry. The selected studies have controlled for industry type (see control variables on page 68 ).
} 
structure would give rise to severe entrenchment effects leading to lower firm performance than otherwise could be.

Premise 6: 'Corporate assets can be less valuable when managed by an individual free from checks on his control' (Morck et al., 1988) - The 'Entrenchment Hypothesis'.

Thus, when the co-operation between blockholders and management cripple the management monitoring function of blockholders, managers are free from checks on their performance. Without checks and control to enforce value maximisation, corporate assets may be deployed to benefit managers rather than shareholders. Fame and Jensen's (1983) empirical study found that firm value is reduced after some level of high ownership concentration because the absence of checks on managerial control induces entrenchment and misallocation of resources. Brickley's et al. (1988) empirical study reported that pressure-sensitive institutions including banks, insurance companies and nonbank trusts are more likely to vote with managers on anti-takeover amendment proposal irrespective of the proposal on firm value.

Consequently, utility maximisation behaviour of manager enabled by certain ownership structure can lead to non-profit-maximising behaviour on the part of the firm under their stewardship (Vroom \& McCann, 2009). The following subsection attempts to test the validity of the hypothesis that ownership concentration affects firm performance using Meta-analysis. In so doing, this paper aims to pin down the range of ownership structures that may negatively affect firm performance by affecting the extent to which managers can be entrenched. From there the paper investigates the NZ situation showing that the nature of firm ownership structure in NZ contributed in an important way to the nation's "long tail of very low performers" firms (MBIE, 2013, p. 3, 8).

\subsection{Assessing Managerial Effectiveness Using a Meta-Analysis}

This subsection investigates the effect on firm performance over the range of ownership concentration. To do this the paper focuses on the effect of managerial/insider equity on agency costs by comparing the behaviour of a manager when they own $100 \%$ of the residual claims on a firm with their behaviour when they sell off a portion of those claims to outsiders. Note as the managers' fraction of the equity fall the fraction of the equity owned by outsiders increase. In the 
past two decades many empirical studies ${ }^{40}$ have been carried-out in this area, thereby providing a good basis for a meta-analysis. A meta-analysis enables one to deduce better inferences on this issue than the result of one study alone. However, because the studies in this area are still evolving, it is premature to provide a complete survey. For this meta-analysis, the paper will confine its attention to several representative studies on ownership concentration - firm performance relation. That is, those studies that examine ${ }^{41}$ :

\section{Firm Performance $=F($ Ownership, Control Variables $)$}

Firm Performance is the dependent variable approximate by Tobin's Q and/or Return on Assets (ROA). Tobin's Q, a ratio devised by James Tobin, hypothesized that the combined market value of all companies on the stock market should be about equal to their replacement costs (Tobin, 1969 , p. 23, 29). In other words, capital should be valued at its reproduction cost and firms should be worth what they cost to replace (i.e. $Q=1$ ). Tobin's $Q$ ratio equals the market value of a company (number of shares outstanding $x$ share price) divided by the replacement value of the firm's assets. Tobin's $Q$ as a measure of firm performance allows studies to use the replacement costs of assets as a yardstick against the market value of firms at a given level of ownership concentration. In this simple representation, Tobin's Q ratio may be interpreted as follows. A given level of ownership concentration - a Q relationship that yields a Q value of one means that the market value of the firm equals the value of the recorded assets of a firm. When such relation yields a value of Q less (greater) than one, it costs more (less) to replace a firm's assets than the firm is worth, respectively.

$$
\begin{aligned}
& \text { Tobin's } Q \text { Premise: Firms should be worth what their assets are worth } \\
& \qquad\left(Q=1=\frac{\text { Capital }}{\text { Costs }} \text {, no resource wastage - efficient }\right)
\end{aligned}
$$

ROA, on the other hand, is an accounting-based performance measure also used (mostly in earlier studies) as a measure of firm performance. ROA equals net income divided by total assets. It is an indicator of how profitable a firm is relative to its total assets. Some authors in the

\footnotetext{
${ }^{40}$ See http://e.viaminvest.com/A5OwnershipStructures/OwPerfStudies/Table_Ow_UVWXYZ.asp

${ }^{41}$ Studies: Jensen \& Meckling (1979), Nuen \& Santerre (1986), Kim \& Lyn (1988), Morck et al. (1988), McConnell \& Servaes (1990; 1995), Hermalin \& Weisback (1991), Leach \& Leahy (1991), Chen et al. (1993), Holderness et al. (1999), Bhabra (2007), Fauzi \&Locke (2012), Wellalage \& Locke (2011; 2012), Jiang et al. (2009), Gedajlovic \& Shapiro (1998).
} 
more recent studies included ROA along with Tobin's Q for robustness (Demsetz \& Villalonga, 2001; Bhabra, 2007; Jiang et al., 2009; Fauzi and Locke, 2012).

Ownership is the independent variable and would be as classified in Table 6 (on page 66). Hu and Izumida's (2008) paper, surveys much of the theoretical and empirical researches on the relationship between ownership structure and firm performance, showing the literature can be divided into two streams. The first is related to the efficacy of concentration of ownership. The second is related to the distinctive motivations, abilities and effectiveness of managerial ownership to influence firm performance. While the first examines the contending efficient monitoring hypothesis ${ }^{42}$ and the expropriation of monitoring shareholder hypothesis ${ }^{43}$ associated with outside block ownership (OUTBLOWN) concentration, the second examines the contending convergence of interest hypothesis ${ }^{44}$ and the entrenchment hypothesis ${ }^{45}$ associated with managerial/insider ownership (INOWN) concentration. Since the purpose of this metaanalysis is about determining managerial effectiveness, this paper therefore focuses on the latter - managerial/insider ownership as a function of performance. That is, the cross sectional relation between insider/managerial ownership (INOWN) and firm performance (proximate by Tobin's Q or ROA). This, in turn, uses as proxy for managerial effectiveness (McConnell \& Servaes, 1995). Nonetheless, for additional insights the issues related to the former will also be discussed.

Since theoretical arguments alone cannot unambiguously predict the association between INOWN and firm performance (proxy for managerial effectiveness), with the convergence of interest hypothesis suggesting an uniformly positive association, the entrenchment hypothesis suggesting firm performance can be adversely affected for some range of high ownership stakes. It is, therefore, not possible, a priori, to predict which force will dominate at any level of ownership. Hence, the association between ownership structure and firm performance is an empirical issue (Morck et al., 1988; McConnell \& Servaes, 1990). The aim of this meta-analysis exercise is to compile the empirical results drawn from a number of relevant studies on the association between insider ownership (INOWN) and firm performance (proxy by Tobin's Q)

\footnotetext{
${ }^{42}$ Efficient monitoring hypothesis: contends that higher concentration of ownership gives large shareholders stronger incentives and greater power at lower costs to monitor management.

${ }^{43}$ Expropriation of monitoring shareholder hypothesis: contends that concentrated ownership structure may permit dominant shareholders to expropriate minority shareholders.

${ }^{44}$ Convergence of interest hypothesis: contends that the propensity for managers to deviate from value maximisation decrease as managerial/insider stockownership increase.

${ }^{45}$ Entrenchment hypothesis: contends that while a manager with smaller shares can disciplined toward firm value maximisation by the market forces, a manager controlled a substantial equity can entrench himself from the market restriction (i.e. the takeover threat or the managerial labour market).
} 
for inference on managerial effectiveness. In particular, this paper investigates whether a high level of INOWN in the firm increases the probability that the manager devotes significant effort to creative activities and immunises himself from misappropriating the firm resources due to his own interests. If so, why? And if not, why not? Thus, essentially investigating Premise 1 to 6.

Table 6 defines ownership structure classification used in this evaluation.

\section{Table 6: Ownership Structure Classification}

\begin{tabular}{|l|l|}
\hline \multicolumn{1}{|c|}{ Category } & \multicolumn{1}{c|}{ Description } \\
\hline Insider Ownership/ Managerial Ownership (INOWN) \\
\hline Management member & $\begin{array}{l}\text { Active member of management board including directors, officers and } \\
\text { individuals actively involved in corporate decisions (may include family } \\
\text { members). }\end{array}$ \\
\hline Outsider Block ${ }^{46}$ Ownership (OUTBLOWN) \\
\hline Corporates & Non-financial company \\
\hline Investment companies & Investment companies, i.e. venture capital and buyout companies. \\
\hline Banks & Mortgage, credit or investment bank (for own account). \\
\hline Insurance companies & $\begin{array}{l}\text { Insurance companies provide coverage in the form of compensation in } \\
\text { exchange for premium payments. }\end{array}$ \\
\hline Government & Municipal, state and federal government. \\
\hline Outside Individuals & Individual persons which are not insiders. \\
\hline Treasury Shares & Shares held by the company itself. \\
\hline Institutionals & $\begin{array}{l}\text { Institutional investors, i.e. asset management companies, pension funds, banks } \\
\text { (for third party account) and so on. }\end{array}$ \\
\hline Employees & Employees of the company excluding members of the board. \\
\hline Others & All shareholders that hold at least 5\% of equity ownership within the firm. \\
\hline Outsider Dispersed Ownership \\
\hline Freefloat & $\begin{array}{l}\text { Freefloat portion of the shares calculated as 100\% less sum of the } \\
\text { shareholdings of all other categories. }\end{array}$ \\
\hline
\end{tabular}

Note: The above classification is used in the selection of studies for this meta-analysis and is characterised by the explicit consideration of ownership concentration (insiders and outsiders). Other categories private households, individuals or families without further distinguishing among different types of individuals (e.g. outsiders and insiders) are not appropriate for this research purpose.

Control variables refer to those variables held constant across firms in order to examine the influence of ownership structures on firm performance. Control variables include debt, R\&D, advertising expenditures, replacement value of assets, firm size, industry type etc. Controlling for such variables helps to improve the precision of the estimates and to reduce much of the omitted variable bias that affects the studies.

Many theoretical and empirical researches in this area are typically derived from studies on publicly listed firms in the United States (US). Among these Nuen and Santerre (1986), Kim

\footnotetext{
${ }^{46}$ Block holder also called majority shareholder or controlling shareholder.
} 
and Lyn (1988), Morck et al. (1988), McConnell and Servaes (1990; 1995), Hermalin and Weisback (1991) and Leach and Leahy (1991), all found the association between insider ownership (INOWN) and firm performance to be non-linear. These studies show within some range of INOWN firm performance increases and within some other range firm performance decreases. For the few studies carried out more recently on New Zealand (NZ) publicly listed firms (Bhabra, 2007; Fauzi \& Locke, 2012; Jiang et al., 2009), the relationship between INOWN and firm performance is also found to be non-linear. However, the inflection points ${ }^{47}$ obtained from the NZ studies were different from those obtained in the US's. Evaluating the cross sectional relationship between INOWN and firm performance (uses as proxy for managerial effectiveness) and investigating why NZ experienced different inflection points compare to those experienced in the US is the subject of the rest of this section.

\subsubsection{Meta-Analysis: Insider Ownership-Tobin's Q Relation}

To deduce better inferences on the issue of managerial effectiveness, approximated by the cross sectional relationship of Insider/managerial ownership (INOWN) and firm performance (proxy by Tobin's Q), one needs to go beyond the examination of a single study. This is because the results of a single study can be influenced by characteristics of the study setting, sampling, timing, methodology and the subjective bias of the researchers. Robustness can only be unearthed by a synthesis of multiple studies. General trends and underlying principles can only be deduced across a large body of case studies or empirical studies. Meta-analysis is an analytical approach with which to gain such additional scientific insights from previous research. The first recordable publication of a 'Meta-analysis' appeared in 1904, addressing the effectiveness of typhoid vaccine (Mak et al., 2010). Since then 'Meta-analysis' has become a widely used research tool, encompassing a range of procedures used in a variety of disciplines, namely psychology, environmental science, and transportation science. At the present time, meta-analysis has increasingly been used in the field of economics, particularly labour and environmental economics. In essence, Meta-analysis can simply be thought of as 'conducting research about research’ (Bergeijk \& Lazzaroni, 2013).

\footnotetext{
${ }^{47}$ The inflection point is the percentage of ownership of equity at which value of Q reaches its maximum or minimum in the estimated regressions.
} 
In this subsection, I adopt meta-analysis techniques as a statistical and analytical procedure for combining and comparing research findings from different studies, focusing on similar phenomena. In this case, the focus is on the cross sectional relationship between INOWN and the Tobin's Q, which in effect uses as proxy for managerial effectiveness. Therefore, the paper takes the definition of "meta-analysis" as "...an analytical framework for comparative research that aims to draw inferences on common issues with different but allied empirical backgrounds" (Matarazzo \& Nijkamp, 1997). In so doing, I hope to identify patterns among these studies' statistical results or relationships that may come to light in the context of multiple studies on INOWN-Tobin's Q dynamics for better inferences on the issue of managerial effectiveness in NZ.

\subsubsection{Search and Selection of Studies for Analysis}

Much theoretical and empirical research has attempted to understand the costs and benefits of insider ownership (INOWN) by examining the cross-sectional relation between INOWN and Tobin's Q (proxy for firm performance). This, in turn, is viewed as a proxy for managerial effectiveness. Studies that consider the INOWN-Tobin's Q relation without considering the effect of block and/or institutional ownership in their regression provide a good basis to test the validity of Premise 1, 2, 3 and possibly 6. Studies that also include block and/or institutional ownership also enable one to test the validity of Premise 4 to 6 . Because of the contending views in Premise 1 to 6, it is not possible, a priori, for one to predict which force will dominate at any level of ownership concentration. Hence, it would be a mistake to use a specification that constrained ownership to affect performance linearly. Therefore, theoretical and empirical studies selected are those using piecewise linear specifications in their analyses.

The primary proposition to test in this meta-analysis is that firm performance is a function of the distribution of equity ownership among corporate insiders, outside blockholders, and individual atomistic shareholders (consistent with the classification in Table 6). Such a function is necessarily non-linear. That is, firm performance does not entirely increasing or decreasing with INOWN. The effect of increasing INOWN on firm performance can be a double-edged sword (Stulz, 1988). That is, while a manager who held smaller equity could be disciplined toward firm value maximisation by the market forces, a manager who controlled significant shares, however, can entrench himself/herself from the market restriction (i.e. takeover threat or the managerial labour market) (Hu \& Izumida, 2008). Hence, the incentive 
effect vs. the entrenchment effect. Table 7 on the next page outlines the sample of studies selected for the analysis. In the empirical studies in Table 7, firm performance variable (i.e. Tobin's Q) is regressed against various measures of ownership (and other control variables) to gauge their impact on firm performance. For the few descriptive studies in the literature included in this paper are included to provide further insights. Note in Table 7 insider ownership (INOWN) and outside block ownership (OUTBLOWN) would be as the percentage of beneficial shares held by insiders and outsiders as defined in Table 6 unless stated otherwise. 
Table 7: Selected Studies on Firm Ownership Structure and Firm Performance

\begin{tabular}{|c|c|c|c|c|}
\hline $\begin{array}{l}\text { Paper } \\
\text { No. }\end{array}$ & Paper Source & $\begin{array}{l}\text { (i) Ownership } \\
\text { Variable }\end{array}$ & $\begin{array}{c}\text { (ii) Firm } \\
\text { Performance } \\
\text { Variable }\end{array}$ & $\begin{array}{l}\text { Relationship between } \\
\text { (i) and (ii) }\end{array}$ \\
\hline PI.1 & $\begin{array}{l}\text { Jensen and } \\
\text { Meckling } \\
\text { (1976) }\end{array}$ & $\begin{array}{c}\text { Insider } \\
\text { Ownership } \\
\text { (INOWN) }\end{array}$ & $\begin{array}{l}\text { Descriptive } \\
\text { firm value }\end{array}$ & $\begin{array}{l}\text { Firm performance increases with INOWN: } \\
\text { showing partial INOWN provides incentives for } \\
\text { consumption of excessive perquisites, but such } \\
\text { incentives decrease as INOWN stake increases } \\
\text { (suggesting convergence of interests as INOWN } \\
\text { increases). However, if the firm is } 100 \% \text { owner- } \\
\text { managed, owner-manager will make operating } \\
\text { decisions that maximise his/her utility (suggesting } \\
\text { substitution of profits for utility maximisation } \\
\text { when INOWN is 100\%). } \\
\text { [Evidence for: Premise 1 and 2] }\end{array}$ \\
\hline PI.2 & $\begin{array}{l}\text { Nuen and } \\
\text { Santerre (1986) } \\
\text { Sample (1980): } 81 \\
\text { Fortune } 500 \text { firms }\end{array}$ & $\begin{array}{c}\text { Outside Block } \\
\text { Ownership } \\
\text { (OUTBLOWN) }\end{array}$ & $\begin{array}{c}\text { Return on } \\
\text { Assets (ROA) }\end{array}$ & $\begin{array}{l}\text { Non-linear: ROA decreases when blockholder } \\
\text { ownership is below } 20 \% \text {, increases when it is } 20- \\
50 \% \text {, and decreases when greater than } 50 \% \\
\text { (suggesting monitoring efficiency with increases } \\
\text { outside block ownership, OUTBLOWN, but the } \\
\text { entrenchment effect sets in when ownership } \\
\text { reaches some significant level). } \\
\text { [Evidence for: Premise 4, } 5 \text { and 6] }\end{array}$ \\
\hline PI.3 & $\begin{array}{l}\text { Kim and Lyn } \\
\text { (1988) } \\
\text { Sample: } 391 \text { US } \\
\text { firms (1976-78) }\end{array}$ & INOWN & Tobin's Q & $\begin{array}{l}\text { Non-linear: When INOWN }<5 \% \text { Q decreases as } \\
\text { INOWN increases; when INOWN }>25 \% \text { Q } \\
\text { increases with INOWN. This is consistent with } \\
\text { PI.1, suggesting that managers of low INOWN } \\
\text { firms would consume more perks (shirking), and } \\
\text { thus firm values would be lower compared to } \\
\text { those of inside-controlled firms. } \\
\text { [Evidence for: Premise 2] }\end{array}$ \\
\hline PI.4 & $\begin{array}{l}\text { Morck et al. } \\
\text { (1988) } \\
\text { Sample: } 371 \text { of } \\
\text { the largest US } \\
\text { firms [Fortune } \\
\text { 500] (1980). }\end{array}$ & $\begin{array}{l}\text { INOWN } \\
\text { [as by officers } \\
\text { and directors on } \\
\text { the board; as by } \\
\text { officers; as by } \\
\text { other directors } \\
\text { on the board] }\end{array}$ & Tobin's Q & $\begin{array}{l}\text { Non-linear: At low INOWN range }(0-5 \%) \text { Q } \\
\text { increases with INOWN; at intermediate INOWN } \\
\text { range }(5-25 \%) \text { Q decreases with INOWN; at high } \\
\text { INOWN }(>25 \%) \text { Q increases with INOWN. } \\
\text { INOWN defines as shareholding by BODs or } \\
\text { INOWN defines as holding by CEO or by other } \\
\text { member of the board - produced similar pattern }{ }^{48} \text {. } \\
\text { Similar results cited in Wruck (1989) (for } \\
\text { incentive and entrenchment effect). } \\
\text { [Evidence for: Premise } 2 \text { and 3] }\end{array}$ \\
\hline PI.5 & $\begin{array}{l}\text { McConnell and } \\
\text { Servaes (1990) } \\
\text { Sample: US firms } \\
\text { listed on NYSE or } \\
\text { AMEX, } 1173 \\
\text { firms in } 1976 \text { and } \\
1093 \text { firms (1986). }\end{array}$ & $\begin{array}{l}\text { INOWN } \\
\text { [as by officers } \\
\text { and board of } \\
\text { directors, } \\
\text { BODs; consider } \\
\text { the effect of } \\
\text { Institutional } \\
\text { investors }\end{array}$ & Tobin's Q & $\begin{array}{l}\text { Non-linear: Q first increases with INOWN then } \\
\text { turn downward. Results cited to be consistent with } \\
\text { Stulz (1988), explaining at } 50 \% \text { INOWN the } \\
\text { probability of a hostile takeover is zero }- \text { absence } \\
\text { of managerial discipline (for incentive and } \\
\text { entrenchment effect). } \\
\text { [Evidence for: Premise 1, 2, } 3 \text { and 6] }\end{array}$ \\
\hline
\end{tabular}

\footnotetext{
${ }^{48}$ This suggested that both the CEO and the outside board members with equity respond to financial incentives could become entrenched.
} 


\begin{tabular}{|c|c|c|c|c|}
\hline & & & & $\begin{array}{l}\text { Authors also show the inclusion of institutional } \\
\text { ownership as an independent variable increases } \\
\text { the inflection point of INOWN-Q relation from } \\
38 \% \text { to } 43 \% \text { (in the } 1976 \text { sample); from } 50 \% \text { to } \\
60 \% \text { (in the } 1986 \text { sample), suggesting institutional } \\
\text { ownership reinforces the positive effect of } \\
\text { INOWN on Q (insider/managerial ownership on } \\
\text { firm performance). } \\
\text { [Evidence for: Premise 5] }\end{array}$ \\
\hline PI.6 & $\begin{array}{l}\text { Hermalin \& } \\
\text { Weisback } \\
\text { (1991) } \\
\text { Sample: } 134 \text { firms } \\
\text { listed at NYSE } \\
(1971,1974,1977, \\
\text { 1980, 1984) }\end{array}$ & $\begin{array}{l}\text { INOWN } \\
\text { [as by all } \\
\text { present and } \\
\text { former CEO's } \\
\text { still on the } \\
\text { BODs] }\end{array}$ & Tobin's Q & $\begin{array}{l}\text { Non-linear: INOWN (as CEO) in } 0-1 \% \text { range Q } \\
\text { increases with INOWN; } 1-5 \% \text { range Q decreases } \\
\text { as INOWN increases; } 5-20 \% \text { range Q increases } \\
\text { with INOWN; and decreases thereafter. Authors } \\
\text { suggest even if on average higher ownership } \\
\text { allows deeper entrenchment diminishing return } \\
\text { might set in well before the } 50 \% \text { INOWN rate. } \\
\text { Hence, the problem of entrenchment is not just a } \\
\text { consequence of voting power. CEO by virtue of } \\
\text { their tenure with the firm, status as a founder, or } \\
\text { even personality, can be entrenched with } \\
\text { relatively small stakes. } \\
\text { [Evidence for: Premise 1, 2, 3 and 6] }\end{array}$ \\
\hline PI.7 & $\begin{array}{l}\text { Leach and } \\
\text { Leahy (1991) } \\
\text { Sample: } 470 \text { UK } \\
\text { large industrial, } \\
\text { firms } \\
(1983-85)\end{array}$ & $\begin{array}{l}\text { Herfindahl } \\
\text { index and } \\
\text { concentration } \\
\text { ratios: } c_{1} \\
\text { (largest } \\
\text { holding), } c_{5}, c_{10} \text {, } \\
\text { and } c_{20} \text { (the } \\
\text { combined } \\
\text { holding of the } \\
\text { largest } 5,10 \text {, } \\
\text { and } 20 \\
\text { shareholders) }\end{array}$ & $\begin{array}{l}\text { Valuation ratio } \\
\text { (VAL); } \\
\text { Returns on } \\
\text { shareholdings' } \\
\text { capital } \\
\text { (RSHC) }\end{array}$ & $\begin{array}{l}\text { More concentration caused significantly less } \\
\text { performance: concentration has negative } \\
\text { coefficient in VAL (ratio reflects market } \\
\text { discipline effect), suggesting adverse effect on } \\
\text { disciplinary force } 49 \text {. Positive effect on RSHC } \\
\text { (proxy for shareholder incentives) but near zero, } \\
\text { indicating that the effect of ownership } \\
\text { concentration via shareholder incentives is } \\
\text { unimportant. } \\
\text { [Evidence for: Premise 6] }\end{array}$ \\
\hline PI.8 & $\begin{array}{l}\text { Chen et al. } \\
\text { (1993) } \\
\text { Sample: Fortune } \\
500 \text { (1976, 1980, } \\
1984)\end{array}$ & $\begin{array}{l}\text { INOWN [as by } \\
\text { officers and } \\
\text { directors] }\end{array}$ & Tobin's Q & $\begin{array}{l}\text { Non-linear: When INOWN }<7 \% \text { Q increases } \\
\text { with INOWN. Q reaches it maximum when } \\
\text { INOWN is about } 7 \% \text {; beyond } 7 \% \text { Q decreases as } \\
\text { INOWN increases; Q increases with INOWN } \\
\text { again when INOWN } \geq 20 \% \text {. } \\
\text { [Evidence for: Premise } 2 \text { and 3] }\end{array}$ \\
\hline PI.9 & $\begin{array}{l}\text { Holderness et } \\
\text { al. (1999) } \\
\text { Sample: } 1236 \text { US } \\
\text { listed firms in } \\
1935 \text { and } 3759 \text { in } \\
1995 .\end{array}$ & $\begin{array}{l}\text { INOWN } \\
\text { [as by officers } \\
\text { and directors] }\end{array}$ & Tobin's Q & $\begin{array}{l}\text { Non-linear: When INOWN }<5 \% \text { Q increases } \\
\text { with INOWN; } 5 \%<\text { INOWN }<25 \% \text { Q decreases } \\
\text { as INOWN increases; INOWN }>25 \% \text { Q increases } \\
\text { with INOWN again but at a slower rate. Authors } \\
\text { suggest, thereafter, at some high level of INOWN } \\
\text { Q would decline again due to issue of managerial } \\
\text { discipline (high managerial control reduce the } \\
\text { probability of a takeover). } \\
\text { [Evidence for: Premise 2, } 3 \text { and 6] }\end{array}$ \\
\hline
\end{tabular}

\footnotetext{
${ }^{49}$ The authors explained: the negative sign in the valuation ratio revealed where ownership is concentrated the market for shares is not developed and this is reflected in an adverse market valuation irrespective of the return on shareholders' capital.
} 


\begin{tabular}{|c|c|c|c|c|}
\hline PI.10 & $\begin{array}{l}\text { McConnell \& } \\
\text { Servaes (1995) } \\
\text { Sample: US firms } \\
\text { listed on NYSE or } \\
\text { AMEX: firms - } \\
\text { 990 (1976), } 876 \\
\text { (1986), } 780 \\
\text { (1988). }\end{array}$ & $\begin{array}{l}\text { INOWN } \\
\text { [as by officers } \\
\text { and BODs]; also } \\
\text { consider the } \\
\text { effect of } \\
\text { blockholder and } \\
\text { Institutional } \\
\text { investors }\end{array}$ & Tobin's Q & $\begin{array}{l}\text { Non-linear: relationship between Q and INOWN } \\
\text { for both samples of low-growth and high-growth } \\
\text { firms, whereby Q first increases and then } \\
\text { decreases, as the fraction of shares owned by } \\
\text { INOWN increases. Pattern consistent with } \\
\text { previous studies, but likely to be more important } \\
\text { for low growth firms. } \\
\text { [Evidence for: Premise 1, 2, } 3 \text { and 6] }\end{array}$ \\
\hline PI.11 & $\begin{array}{l}\text { Bhabra (2007) } \\
\text { Sample: NZ's } \\
\text { listed firms panel } \\
\text { data over 1994- } \\
1998\end{array}$ & $\begin{array}{l}\text { INOWN [as by } \\
\text { directors] }\end{array}$ & Tobin's Q & $\begin{array}{l}\text { Non-linear: When INOWN is less than } 14 \% \text { and } \\
\text { greater than } 40 \% \text { Q increases with INOWN; but } \\
\text { when INOWN is between } 14 \% \text { and } 40 \% \text { Q } \\
\text { decreases as INOWN increases. Author shows } \\
\text { results are robust to different measures of firm } \\
\text { performance and several different estimation } \\
\text { techniques and to differences in governance } \\
\text { structures across markets. } \\
\text { [Evidence for: Premise 2 and 3] }\end{array}$ \\
\hline PI.12 & $\begin{array}{l}\text { Fauzi and } \\
\text { Locke (2012) } \\
\text { Sample: } 79 \mathrm{NZ} \\
\text { listed firms, } \\
\text { balanced panel } \\
(2007-2011) \\
\end{array}$ & $\begin{array}{l}\text { INOWN } \\
\text { [as by officers]; } \\
\text { also considering } \\
\text { the effect of } \\
\text { outside } \\
\text { blockholder }\end{array}$ & $\begin{array}{c}\text { Tobin's Q and } \\
\text { ROA }\end{array}$ & $\begin{array}{l}\text { Non-linear: when INOWN }<15.4 \% \text { Q increases } \\
\text { with INOWN; when INOWN }>17.4 \% \text { decreases } \\
\text { as INOWN increases; result consistent with } \\
\text { previous studies for a non-linear relationship. } \\
\text { [Evidence for: Premise 1, 2, 3, and 6] }\end{array}$ \\
\hline PI.13 & $\begin{array}{l}\text { Wellalage \& } \\
\text { Locke }(2011 ; \\
2012)^{50} \\
\text { Sample: small } \\
\text { unlisted NZ firms } \\
(1998-2008)\end{array}$ & INOWN & $\begin{array}{l}\text { Infer firm } \\
\text { performance } \\
\text { from ownership } \\
\text { concentration- } \\
\text { agency cost } \\
\text { relation. }\end{array}$ & $\begin{array}{l}\text { Non-linear: when INOWN is negligible }(<0.2 \%) \\
\text { or too high }(\geq 75 \%) \text { agency costs (both Principal- } \\
\text { Agent and Principal-Principal costs) increases, } \\
\text { and thus firm performance would be lower. } \\
\text { [Evidence for: Premise } 2,3 \text { and 6] }\end{array}$ \\
\hline PI.14 & $\begin{array}{l}\text { Jiang et al. } \\
(2009)\end{array}$ & OUTBLOWN & $\begin{array}{l}\text { Tobin's Q; } \\
\text { ROA }\end{array}$ & $\begin{array}{l}\text { Non-linear: finds high ownership concentration } \\
\text { in NZ does not constrain excessive management } \\
\text { power, but execrates agency problems associated } \\
\text { with executive pay; providing evidence for the } \\
\text { debate - whether ownership concentration } \\
\text { encourages efficient monitoring or rent seeking } \\
\text { with respect to executive pay. } \\
\text { [Evidence for: Premise } 3 \text { and 6] }\end{array}$ \\
\hline PI.15 & $\begin{array}{l}\text { Gedajlovic \& } \\
\text { Shapiro (1998) } \\
\text { Sample: } 1030 \\
\text { medium to large } \\
\text { sized public and } \\
\text { private sector } \\
\text { firms, drawn from } \\
5 \text { countries } \\
\text { (1986-91). }\end{array}$ & $\begin{array}{l}\text { INOWN } \\
\text { OUTBLOWN }\end{array}$ & ROA & $\begin{array}{l}\text { Evidence for differences across countries: Non- } \\
\text { linear: United States, United Kingdom, Germany. } \\
\text { No effect: Canada and France. Authors suggest } \\
\text { such differences indicate that the constraints on } \\
\text { managerial discretion do vary in effectiveness } \\
\text { across countries. They suggest this may be due to } \\
\text { differences in the level of diversification and } \\
\text { internal constraints across countries. }\end{array}$ \\
\hline
\end{tabular}

Source: Own collaboration based on quoted studies.

\footnotetext{
${ }^{50}$ Data made available by the Management Research Centre at the University of Waikato. (2011): unbalanced panel dataset given high attribution rate for SMEs, comprises of 1099 observations from a total of 100 businesses (19982008); (2012): balanced panel dataset, comprises 2640 observations from a total of 240 businesses (1998-2008). The random sample is drawn from accounting practices that prepare end of year financial returns for small businesses, and thus avoiding selection bias of using bank related data or survey those businesses submit to government agencies. Firms included in both studies come from a range of industries, categorised as primary, energy, goods, services, and others.

${ }^{51}$ CAN 8.8\%; UK 12.9\%; US 60.7\%; FRA 8\%; GER 9.6\%; 11 industrial sectors (1986-91).
} 


\subsubsection{Results and Analysis - The United States Studies}

The objective of this meta-analysis exercise is to determine the extent to which there is a generalisable pattern of the cross sectional relationship between insider ownership (INOWN) and Tobin's Q (proxy for firm performance) drawn from a number of relevant studies for inference on managerial effectiveness. Recall that Tobin's Q (hereafter Q) is the ratio of the firm's market value to the replacement cost of its assets. This means that a $\mathrm{Q}$ above (below) one would indicate that the market views of the firms' internal organisation as exceptionally good (poor) or the expected agency costs are particularly small (large), and thus the firms would be valued higher (lower), respectively. A statistical compilation of the U.S. empirical studies by Morck et al. (1988), Chen et al. (1993) and Holderness et al. (1999), from Table 7 reveal the following pattern, as illustrated in Figure 16. While Nuen and Santerre (1986), Kim and Lyn (1988), McConnell and Servaes (1990; 1995) and Hermalin \& Weisback's (1991) findings help validate the pattern in Figure 16 and provide further inferences regarding their implications. Jensen and Meckling's (1976) theoretical study on the other hand, also helps explain the statistical pattern in Figure 16.

In Figure 16 below, the boxplot is constructed from the reported statistical results of Morck et al. (1988), Chen et al. (1993) and Holderness et al. (1999), PI.4, 8 and 9 in Table 7. As in Figure 14, the boxplots in Figure 16 read as follows. The box shows the interquartile range containing the values between $25^{\text {th }}$ and $75^{\text {th }}$ percentile of the sampled studies' estimated effect of INOWN on Q. Recall that this, in turn, is taken as proxy for managerial effectiveness. That is, at a given level of INOWN how effective is management in managing the resources under their stewardship to generate value for their shareholders (through higher firm performance). The white and black areas in the box are the upper quartile and lower quartile range, respectively. The line in between the white and the black area is the median. The upper and lower whiskers are the upper and lower adjacent values. The distance between the highest adjacent value (maximum) and the lowest adjacent value (minimum) gives the spread of the estimated effect of INOWN on Q at a given level of INOWN. 
Figure 16: Tobin's Q as a Function of Insider Ownership (The US Studies)

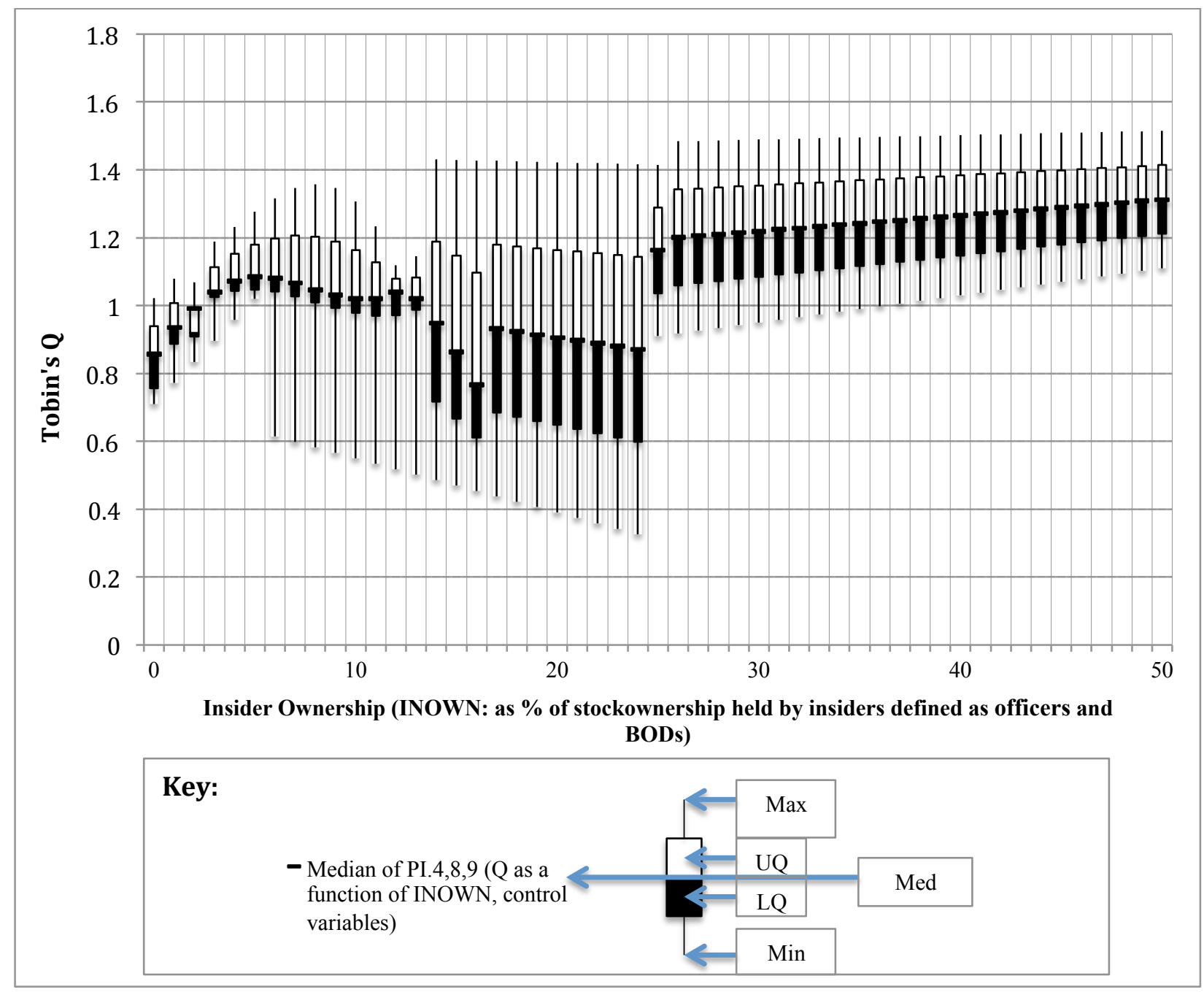

Note: INOWN denoted Insider Ownership. Boxplot constructed from empirical studies PI.4, 8 and 9 mapped out Tobin's Q as a function of INOWN after controlling for variables likely to be correlated with firm performance. Regression specification: Tobin's $\mathrm{Q}=\left\{\beta_{0}+\beta_{1}(\right.$ INOWN $\left.)+\beta_{2}(I N O W N)^{2}+\beta_{3}(\text { INOWN })^{3}\right\}$ or $Q=\left\{\beta_{0}+\right.$ $\left.\beta_{1}(I N O W N 0-5)+\beta_{2}(I N O W N 5-25)+\beta_{3}(I N O W N>25)\right\}$. Control variables include debt, research and development advertising expenditures and replacement value of assets, total assets. Source: [PI.4] Morck et al. (1988), [PI.8] Chen et al. (1993), and [PI.9] Holderness et al. (1999). Dataset available upon request from p_sodany@yahoo.co.uk

Overall, the pattern in Figure 16 shows managerial effectiveness (proximate by the cross sectional relationship between INOWN on Q) are positive and increasing over some range of INOWN (insider/managerial ownership) and negative and decreasing over some range of INOWN. Figure 16 reports that, on average, when INOWN is less than 5\% Q increases by 0.05 with each additional $1 \%$ increase in INOWN. However, when INOWN is between $5 \%$ and $25 \%$ Q decreases, on average, by 0.006 with each additional $1 \%$ increases in INOWN, and beyond $25 \%$ INOWN Q increases again but at a slower rate, on average, by 0.004 with each additional $1 \%$ increase in INOWN. This implies that, on average, when insider/managerial ownership 
(INOWN) is low increasing insider/managerial ownership lead to higher managerial effectiveness. The explanation of this is grounded in the Agency Theory (AT), which defines a firm as a nexus of contracts in which the relationship between managers (agent) and shareholders (principal) is inherently pervaded with conflicts of interest. AT predicts that when managers own little or no stake in their firm they would engage in opportunistic behaviour for their personal benefits at the cost of firm performance. Hence, consistent with the convergence of interest hypothesis (Premise 2) increasing managerial/insider ownership (INOWN) from a negligible level to a higher level would incentivise managers to devote significant effort to creative activities because they bear greater fraction of the benefits from the resultant gains.

However, as managerial ownership increases beyond some level where managers have enough voting power or influence more generally to guarantee their employment with the firm managerial effectiveness worsens. This is because the absence of the potential threat of takeover to serve as a disciplinary device for ineffective and entrenched managers leaves managers relatively free to exercise their discretions. Demsetz (1983) and Fama and Jensen (1983) suggest this would come at the cost of firm performance when the expected benefits derive from managers' other interests (i.e. pay, perks and perquisites) offset the benefits gain from profit maximisation encourage managers to engage in opportunistic and inefficient behaviour (as cited in Hu \& Izumida, 2008). That is, the entrenchment effect (Premise 3). Nonetheless, at high level of INOWN, i.e. after $25 \%$, firm performance, once again, increases with INOWN. Cho (1998) suggests, ceteris paribus, this is because managers prefer equity when they expect their firm to perform well, and thus higher level of managerial ownership is expected in firms with high performance.

Overall, the pattern in Figure 16 confirms the non-linear relationship between insider ownership (INOWN) and firm performance (proxy by Tobin's Q), showing evidence for the convergence of interest or incentive effect occurring at low and high INOWN range and the entrenchment effect occurring at the intermediate INOWN range. The extent to which managers can be entrenched and how long they remained entrenched varied across studies, as illustrated by the large spread reported in the boxplot when INOWN is between $5 \%$ and $25 \%$. This is consistent with Morck et al. (1988) and McConnell and Servaes (1990) who point that it is not possible, a priori, to predict which force will dominate at any level of ownership, and thus the association between ownership structure and firm performance is an empirical issue. Consequently, though the findings of Nuen and Santerre (1986), Kim and Lyn (1988), and 
Hermalin and Weisback (1991) suggest a similar pattern, the inflection point when entrenchment sets in and how long managers remained entrenched reported by these studies do varies.

Notice that the magnitude of the incremental change in Q is quite small. This may be due to the fact that the sampled firms are predominately large firms (McConnell \& Servaes, 1990). In this sample, while entrenchment can be expected to increase with the size of managerial shareholdings, keeping this fraction constant, managerial entrenchment will also increase with the size of the firm (Gugler et al., 2003). This is because, ceteris paribus, with imperfect capital markets it costs disproportionately more for an outsider group to take over a ten billion dollar firm than one worth one billion. There are also other reasons why firm size and performance might be related. To the extent that firm size is related to market shares a positive relationship between size and performance might be expected, due to market power or efficiency effects of scale and scope. This may reduce the observed negative effect of managerial entrenchment. Consequently, one would expect the size of the entrenchment effect to be higher for an economy with smaller firms.

Additionally, the regression results used in Figure 16 also do not account for the presence of block and institutional investors. Jensen and Meckling (1976) and Morck et al. (1988) suggest that in absence of block and institutional investors, monitoring activities may not be effective because of excessive monitoring costs in firms where ownership is widely dispersed among many shareholders. Hence, ineffective monitoring may also explain why Q (firm performance) increases with INOWN (insider ownership) but the observed increase is small and even smaller as INOWN increases beyond $25 \%$ rate. Such results are consistent with Premise 1, 4, 5, and 6. There are reasons to suspect that in absence of monitoring, higher equity ownership by insiders allows managers greater discretion, as Williamson (1988, p. 567) pointed out "debt governance works mainly out of rules, while equity governance allows much greater discretion".

In fact, McConnell and Servaes (1990) show that if one considers the cross sectional relationship between INOWN and Tobin's Q (proxy for managerial effectiveness) with the presence of institutional investors (INSTO), diminishing returns set in much later and the magnitude of the effect of INOWN on Q appeared to be much higher. For both their 1976 and 1986 samples the point of inflection increased approximately by $15 \%$ with the inclusion of INSTO as additional independent variables. They suggest that the presence of INSTO reinforces the positive effect of insider ownership (INOWN) on firm performance (Q) because institutional 
investors (INSTO) provides an effective mechanism to safeguard against managerial entrenchment over and above what can be achieved by small atomistic shareholders. The positive effect occurs because INSTO are more efficient monitors of managers than are atomistic shareholders. Such a result reinforces the efficient monitoring hypothesis of Pound (1988), and consistent with Premise 4 and 5. McConnell and Servaes (1995) further suggests that the presence of INSTO is likely to be more important for low-growth firms than for high-growth firms, after having compared the differences in the effect of INOWN on Q for firms with many growth opportunities (high-growth) to those with few profitable growth opportunities (lowgrowth).

Nonetheless, McConnell and Servaes (1990) show that if outside block owners were merely passive investors with a relatively inactive role in monitoring managerial activities, managerial effectiveness would be lower. They suggest such blockholders may be a descendent of the firm founder and might most appropriately be considered as insiders. This specification may also holds if blockholders co-operate or operate in conjunction with managers instead of monitoring them. In either case, whatever the underlying assumption may be, the passivity of blockholders that result, in effect, means managers are left relatively free from checks on their controls. Consequently, under such circumstance one would expect greater managerial discretion with outside block ownership, leading to lower firm performance than otherwise would be the case (consistent with Premise 6; see evidence of this in Table 2 of McConnell \& Servaes, 1990).

Furthermore, although typically an individual or group must own at least $51 \%$ of the shares to gain control of the firm, in practice entrenchment is not just a consequence of voting power. Some CEO, by virtue of their tenure with the firm, status as a founder, or even personality, can be entrenched even with relatively small stakes. Weston (1979) reported that no firm with insiders owning over 30\% had ever been acquired in a hostile takeover (as cited in Morck et al., 1988). Hence, even if we believe that, on average more ownership allows deeper entrenchment it is possible for diminishing returns to set in well before $50 \%$ ownership is reached (McConnell \& Servaes, 1990; Stulz, 1988; Hermalin \& Weisback, 1991). This explains why the point of diminishing returns across all studies take place before $50 \%$ of insider ownership (INOWN) and why in absence of effective monitoring on managerial control entrenchment would set in far earlier and its effect can be much deeper than would otherwise be the case (Hermalin \& Weisback, 1991). 
In sum, irrespective of the managerial stake in the firm, the absence of checks on managerial control would reduce managerial effectiveness and hence firm performance would necessarily be lower. At this level of aggregation, such results are not inconsistent with the conjecture that large blockholders and inside owners operate in conjunction with each other to influence firm value. Holderness et al. (1999) also highlight a similar proposition in their analysis, suggesting that when blockholders (majority shareholders) collude with corporate managers against the best interests of atomistic (minority) shareholders, either because it is in their interest to do so or because corporate managers coerced them into doing so, firm value would be lower. Thus, one would expect that at some high level of ownership concentration Q declines.

A UK study by Leach and Leahy (1991) echoed similar findings. They found more concentration caused statistically significantly less performance in terms of historic market value/ordinary share capital and return on sales. Overall, these results illustrate that managerial shareholding may have two contrary effects: an incentive effect and an entrenchment effect. Though the above analysis suggests that the former would dominate at low and high ranges of insider ownership (INOWN) and the latter dominates at the intermediate range of INOWN, the inflection points at which the insider ownership-firm performance (INOWN-Q) relation curve changes from being concave to convex to concave again, however, do vary across samples. More importantly, the extents to which managers can be entrenched and for how long they can remain entrenched also vary (see PI.1 to PI.10 in Table 7 for the summary of these studies' results; for further detail refer to the original papers). From this one can infer that at what level of INOWN in which the entrenchment effect may set in and for how long managers can be entrenched depends on the characteristics of the insiders (whether they are CEO or directors or outsiders on the board) and the characteristics of outside shareholders (i.e. dispersed or concentrated) and their behaviour (i.e. monitoring or colluding with management).

Gedajlovic and Shapiro's (1998) investigation of the effect of outside block ownership (as percentage of ownership held by the largest shareholders, institutional and/or block) in the United States, United Kingdom, Germany, Canada and France brings to fore further implications of the association between INOWN and Q (proxy for managerial effectiveness). They show the effect of outside block ownership (OUTBLOWN, as classified in Table 6) differs across countries, suggesting that constraints on managerial discretion do vary in effectiveness across countries. They find strong ownership concentration effects in the United States (US), weaker 
effects in Germany, some effects in the United Kingdom (UK), and no effects at all in Canada or France. They explain that differences may be driven by the differences in the level of diversification ${ }^{52}$ and internal constraints ${ }^{53}$ across countries. Given such cross-countries differences on the effectiveness of outside block owners in reinforcing managerial effectiveness, it is essential to investigate the cross sectional relationship between insider ownership and Tobin's Q with the inclusion of OUTBLOWN (and control variables) in the New Zealand (NZ) context. Comparing the results found in NZ to those evidenced in the US (the subject of the majority of empirical studies in this area) would enable one to better assess the extent to which post reform NZ's high ownership concentrations influenced its managerial effectiveness and thus firm performance.

\subsubsection{Results and Analysis - The New Zealand Studies}

Unlike the United States (US), New Zealand (NZ) has a smaller market and so its listed firms are likely to perform differently. Additionally, the NZ economy comprises mainly of small and medium enterprises, which is different to other developed countries. Bhabra's (2007) study of the effect of insider ownership (INOWN: as a percentage of equity ownership by directors) on firm performance (proxy by Tobin's Q) in NZ publicly listed firms reported a range of 14-40\% within which managerial entrenchment might occur. Though consistent with Premise 2 and 3, the results reported in Bhabra's (2007) NZ study, as illustrated in Figure 17 below, differs from that of the US studies (cf. Figure 17 vs. Figure 16) in three ways. Firstly, the entrenchment effect in NZ sets in at a higher INOWN rate than that reported in the US (i.e. $14 \%$ in NZ vs. $5 \%$ in the US). Secondly, the period in which managers can be entrenched is shown to be longer in NZ than that reported in the US (i.e. the range reported in NZ is between $14-40 \%$ vs. the $5-25 \%$ range reported in the US studies). Thirdly, the magnitude of the entrenchment effect is also reported to be much greater in NZ than that reported in the US (i.e. the lowest Q reported in Figure 17 is less than 0.4 vs. the result reported in Figure 16 whereby the median Q never fell below 0.75 ).

\footnotetext{
${ }^{52}$ Author showed for the United States (US), ownership concentration does not exert a positive marginal effect on profitability unless the firm is either highly diversified or highly concentrated. They showed the interaction between ownership concentration and diversification positively affects profitability in the US.

${ }^{53}$ E.g. compared to the US, the United Kingdom (UK) managers faced stronger internal constraints from their boards since UK directors are legally required to represent the interests of employees as well as shareholders (Clark, 1985 as cited in Gedajlovic \& Shapiro, 1998).
} 
Figure 17: Tobin's Q as a Function of Insider Ownership (The NZ Study)

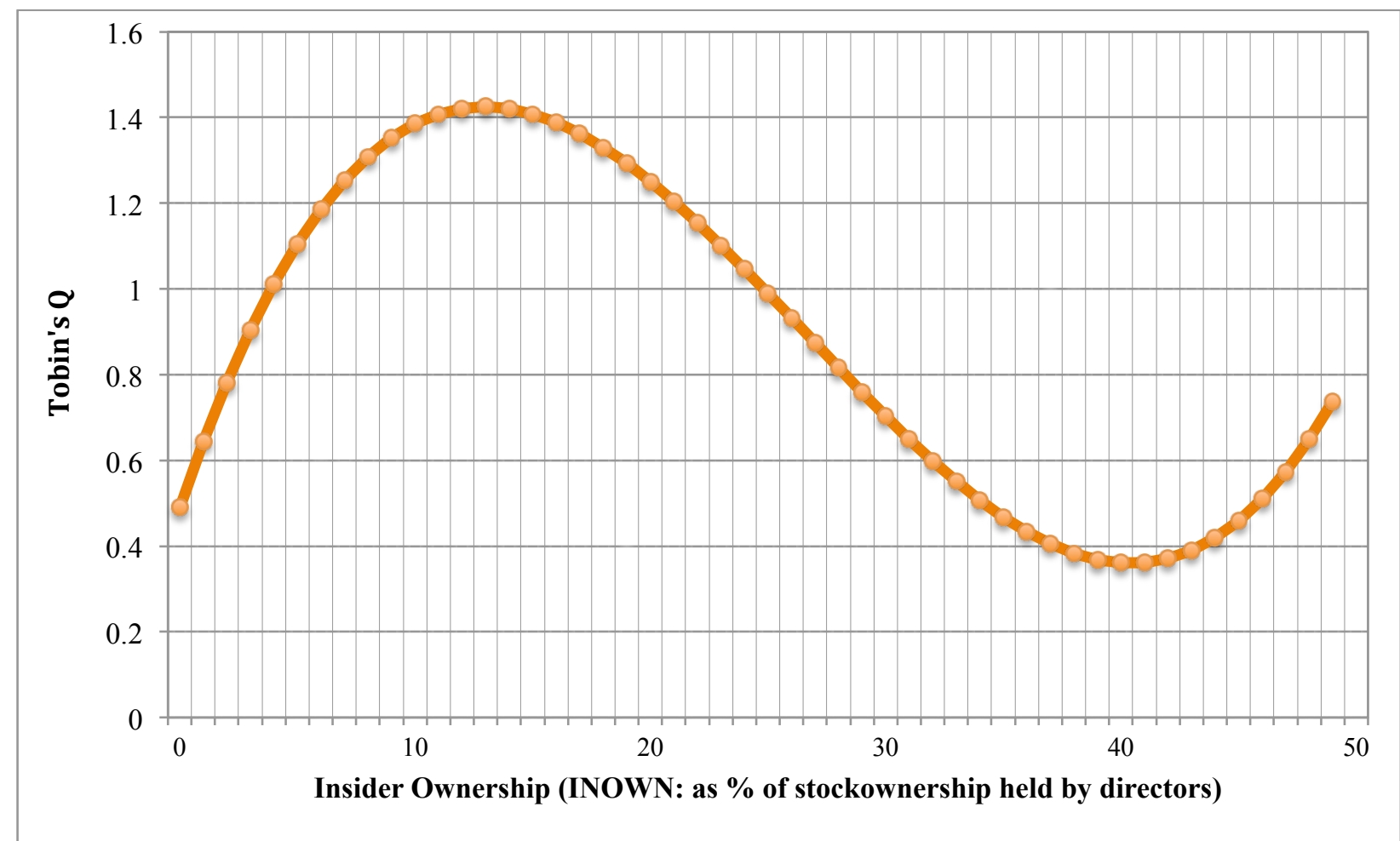

Note: The function constructed from empirical studies by Bhabra (2007) mapping out Tobin's Q (proxy for firm performance) as a function of INOWN after controlling for variables likely to be correlated with firm performance. Regression specification: Tobin's $\mathrm{Q}=\left\{\beta_{0}+\beta_{1}(I N O W N)+\beta_{2}(I N O W N)^{2}+\beta_{3}(I N O W N)^{3}\right.$, control variables $\}$. Control variables include debt, block and firm size. Dataset available upon request to p_sodany@yahoo.co.uk

The effect of entrenchment may set in later in NZ because the NZ market is much smaller than the US, and thus managerial actions may be more transparent in such an environment (Bhabra, 2007). The major legislative reforms in 1993 on the governance of securities, including the Companies Act in 1993 that substantially increased director accountability may also explain why entrenchment effect set in at a much higher rate of insider ownership (INOWN) at 14\% in the NZ study (cf. the 5\% INOWN rate largely reported in the US studies). Additionally, Bhabra (2007) defined insiders as directors (in Figure 17), while the US studies examined in Figure 16 defined insiders as officers and directors. Hermalin and Weisback's (1991) suggest that the problem of entrenchment is not just a consequence of voting power, Chief Executive Officers (CEOs) by virtue of their tenure with the firm or status as a founder can be entrenched with relatively small stakes. Hence, by definition of INOWN, one would expect entrenchment to set in at a relatively higher rate of INOWN in the NZ study compared to the US.

However, the extent to which NZ's managers can be entrenched (be inefficient) is much greater than the 5 to $25 \%$ insider ownership (INOWN) range largely reported in the US studies. 
Even after considering the presence of outside block ownership (OUTBLOWN as classified in Table 6), the range in which managers can be entrenched reported in Bhabra's (2007) NZ study is between $14 \%$ and $40 \%$ INOWN. This result, supported by Healy (2001), supports the proposition that large block and institutional ownership (OUTBLOWN) in NZ do not reinforce the positive effect of insider ownership on firm performance hypothesized by the monitoring efficiency hypothesis. The negative association between block ownership and Q reported in Bhabra (2007) also reinforces this proposition. A number of authors suggest that this is because $\mathrm{NZ}$ institutional investors and blockholders play a very passive role in monitoring firms (Healy, 2001; Bhabra, 2007; Jiang et al., 2009). They argue the possible reasons for this are two-fold.

Firstly, local institutions seem to place less confidence in the NZ equity market and tend to invest their capital in foreign equity markets because of NZ's relative equity market underdevelopment. Secondly, foreign financial institutions and corporations account for the majority of investments in NZ. Healy (2001) reported that as of 31 March 2001, foreign institutions and corporations collectively held $54 \%$ of NZ equities while local institutions held a meager $15 \%$. Other investors whom are not institutional investors hold the rest. The release of the Deloitte/Management Top 200 Company list for excellence in New Zealand business management and governance in 2012 showed that 102 of the Top 200 firms are at least 50\% foreign owned (New Zealand Herald, 2012b). Healy (2001), Bhabra (2007) and Jiang et al. (2009) argue the geographical separation of those foreign institutional investors from their invested firms make collaboration and monitoring among block and institutional investors difficult and costly. Such barriers might largely be responsible for the lack of shareholder activism and ineffective institutional monitoring observed in NZ.

The lack of shareholder activism and ineffective institutional monitoring might also be related to the fact that the presence of foreign ownership in NZ are not as they are, for example, in Canada. Foreign ownership in Canada comes from Foreign Direct Investment (FDI) where foreign multinationals, says from the US, have a branch in Canada with their staffs in Canada to monitor their firms' operations (Brune \& Sweeny, 2012). Hence, a further question to ask is whether foreign ownership in NZ is a direct foreign ownership where foreign block/institutional investors actually have a stake in the firm or whether it is a portfolio foreign ownership where foreign block/institutional investors just owned shares in the firm? And how are they monitoring firms in NZ? Therefore, a more detailed study investigating the structure of foreign ownership in NZ firms relative to other advanced OECD countries would be useful. 
The magnitude of the entrenchment effect is shown to be higher in Bhabra (2007) than the results reported for the US even after having controlled for firm size and block holdings. Tobin's Q is not binary. This means the value far below (above) one would be relatively worse (better) than the value being only slightly below one. Consequently, the greater magnitude in effect shown for NZ indicates that without scale efficiency (because NZ's firms are predominantly small) to offset the adverse effect of entrenchment, firm performance would be lower than might otherwise be the case. Hence, managerial ineffectiveness would be more detrimental to NZ firm performance than that of the US (where firms are larger).

The difference in firm ownership structure in NZ before and after the reform and its effect on managerial effectiveness largely explain why firm performance and productivity differs between these periods. From 1962 to 1993, there had been a major shift to OUTBLOWN (or majority control) among the NZ publicly listed firms, increasing from $16.3 \%$ in 1962 to $50 \%$ by 1993. Whilst the proportion of Insider/managerial ownership (INOWN) in NZ's publicly listed firms declined from 39.5\% in 1962 to only $2.6 \%$ by 1993 (Fox, 1996). Healy (2001) reported outside block ownership (OUTBLOWN) in NZ's publicly listed firms further increased to 69\%, much higher than that of the US (39.8\%) and the UK (60.8\%) (as cited in Bhabra, 2007, p. 1445). Additionally, Hossain et al. (2001) reported that the mean proportion of stock held by the top 20 shareholders in NZ is $73 \%$. At least up to 2001, NZ's publicly listed firms in the post reform era typically are one of low INOWN and high OUTBLOWN (cf. moderate INOWN and relatively dispersed-moderate OUTBLOWN before the reform).

Using a balanced panel of $79 \mathrm{NZ}$ publicly listed firms for the period 2007 to 2011 Fauzi and Locke (2012) verify that the association between INOWN and Q with the presence of OUTBLOWN found in NZ had been different to that found in the US. That is, the presence of OUTBLOWN had not induced effective monitoring expected to smooth out the entrenchment effect as found in the US McConnell and Servaes' (1990) study. McConnell and Servaes' (1990) analysis show with the inclusion of OUTBLOWN, the entrenchment effect can be smoothed out and managerial effectiveness continued to increase until diminishing returns set in at $40 \%$ INOWN. By contrast, Fauzi and Locke (2012) found even with the inclusion of OUTBLOWN the entrenchment effect cannot be smoothed out in NZ and thus managerial effectiveness 
declines after $17.4 \%$ INOWN $^{54}$. Fauzi and Locke (2012) also report a negative association between OUTBLOWN and Q, while McConnell and Servaes' (1990) US study report a positive association. These echo Bhabra's (2007) assertion that contrary to what is found in the US, large outside block ownership (OUTBLOWN) in NZ does not reinforce the positive effect of insider ownership (INOWN) on firm value (Tobin's Q). Thus, Premise 5 does not hold for NZ.

Consequently, despite the higher institutional and concentrated shareholdings (OUTBLOWN) in NZ, and contrary to the results reported for the US and in the larger literature, for some reason the overall effectiveness in OUTBLOWN's ability (and willingness) to monitor management is at best weak. Bhabra (2007) argues that the geographical separation of large (foreign) institutional investors from the firms they own stocks in (NZ) largely account for this. This result is similar to what is found in Fitzsimons (1997) and Hossain et al. (2001). Hence, consistent with Premise 6, the absence of checks on managerial control (monitoring) on the part of outside block holders would leave managers relatively free to exercise their discretion and thus the extent to which managers can be entrenched. This in effect leads to lower firm performance than otherwise would be the case.

Of course, publicly listed firms are not the only firms in NZ. Small businesses account for over 90 per cent of business entities in NZ with more than 586,000 people $(30 \%$ of the workforce) employed in enterprises with fewer than 20 employees. These figures do not account for the 380,000 self-employed in NZ (MBIE, 2014). Ownership structures of private and small businesses vary. MBIE's (2014, p. 15) Small Business Sector Report revealed ownership structures adopted in these smaller firms range from sole proprietorship, partnerships and trusts, to limited liability companies. The allocation of equity ownership may vary from $100 \%$ insider ownership (INOWN) to a much lower level. Nonetheless small businesses in general are ownermanaged. That is, owners/founders more often than not would be part of the management team. Due to lack of reliable data on small businesses, the association between ownership structure and $\mathrm{Q}$ in this area remains relatively unexplored.

Limited as it, a study by Wellalage and Locke $(2011$; 2012) of small-unlisted New Zealand companies (1998-2008) provides a good basis for one to deduce some important inferences from. Wellalage and Locke's $(2011,2012)$ study shows, when insider ownership

\footnotetext{
${ }^{54}$ Note: Fauzi and Locke (2012) defined INOWN as percentage of equity ownership held by managers (officers). The inflection point may be higher if INOWN is measured as the percentage of equity ownership held by directors as in Bhabra (2007) - according to Hermalin and Weisback's (1991) suggestion discussed previously.
} 
(INOWN: defined as equity ownership by owner-manager) is between $0 \%$ and $50 \%$, agency costs decrease (implying firm value increase) with increasing INOWN. This is consistent with Premise 2. However, when insider ownership (INOWN) is at the range greater than $50 \%$, agency costs increase (implying firm value decrease) with increasing INOWN. This is consistent with Premise 1, 3 and 6. Although, on average, higher equity ownership allows deeper entrenchment but given the nature of private and small businesses in New Zealand (NZ) which are typically family owned and managed by the owners, the lack of governance structure (and external pressure) means diminishing return may set in well before $50 \%$ INOWN is reached. More exploration in this area is called for given the importance of small businesses in NZ.

A further investigation into the structures and types of co-operatives, their behaviour, and impact on firm performance would also be helpful. Co-operatives are major players in NZ. They come in many kinds and sizes, ranging from craft co-operatives with a single shop-front to NZ's largest commercial business, Fonterra. Co-operatives are user owned and controlled with owners (often producers or employers or consumers) whom supposedly monitoring the managers (Cooperative Business New Zealand, 2014). Yet, the performance of our largest commercial cooperative, for instance, in terms of growth enhancing innovation and value-added appeared to be lower by international comparison (see Box 3 on page 100 for example). Hence, understanding the behaviour of different types of co-operatives would provide further insights on this issue ${ }^{55,56}$.

In sum, contrary to the US, block and institutional investors in NZ firms do not reinforce the positive effect of insider ownership (INOWN) on firm value because of ineffective monitoring. The geographical separation of NZ's foreign institutional investors (which account for the majority of investments in NZ) from their invested firms may be responsible for this. Reflected in the literature, in absence of effective monitoring (irrespective of the level of managerial stakes in the business) high outside block ownership (OUTBLOWN) concentration

\footnotetext{
${ }^{55}$ For instance, whether problems for co-operatives, in particular, are due to the structure of the firms or their practices. If problems are due to firm's practices: may be there's certain culture or attitude in NZ that is hurting the NZ industries? May be there is a problem in managerial education - e.g. managers have the wrong model in their mind of what 'best practice' is? (E.g. how to increase competitiveness - firms can be competitive on the basis of low price and low quality but this is not the best practice from the point of view of high quality and high productivity.)

${ }^{56}$ In order to understand the overlap between management and efficiency one has to go into the 'black-box' of the firm to figure out what is going on. Economic models need to be more sophisticated, just having a profit maximising function is not going to tell us the full story. It is important to understand how firms are managed. One cannot simply assume (as in the conventional economic model) that somehow everything suppose to workout, that everyone have the same preference function, and that somehow ones' utility maximising function is consistent with their profit maximising function.
} 
would be detrimental to managerial effectiveness, and thus firm performance. They do so by exacerbating the agency costs associated with managerial entrenchment - pay, perks and perquisites. Recall that the passivity of large block holders may warrant such investors to also be classified as insiders, as suggested by McConnell and Servaes (1990). In this respect, one can see why high block ownership in NZ firms would indirectly give managers substantial control of firms irrespective of the managerial stakes in the business. This combined with ineffective monitoring on the part of institutional investors (INSTO) because of the geographical separation of such investors from their invested firms in NZ gives managers much greater discretion, leaving them relatively free from pressure to deliver on performance, and thus leading to lower firm performance than might otherwise be the case.

Consequently, in absence of effective monitoring, the link between private ownership and efficient resource utilisation guided by the profit maximisation constraint would be broken by a highly concentrated ownership structure that reduces the incentives of corporate managers to maximise profits by maximising productivity. The divergence of actual performance from the predicted level based on compliance, in effect, would arise largely as a consequence of inappropriate ownership structure that incentivises managerial entrenchment at the cost of firm performance. This would explain the "long tail of very low performers" firms in NZ (MBIE, 2013 , p. 3, 8). This provides evidence for the proposition that the incentives for managers to perform their functions well (effectively and efficiently), is critically important. This is because outcomes depend not just on their ability. This has important implications on firm performance, growth and productivity.

\subsubsection{Considerations}

Under the condition of underinvestment, Tobin's Q might be inflated (Dybvig \& Warachka, 2010). This is because underinvestment would lead to a proportional reduction in capital that lowers the denominator (replacement costs) of Tobin's Q, but a less than proportional reduction in the numerator since the combination of decreasing marginal revenue and increasing marginal costs reduces the marginal profit of additional output, and thus the value of the firm. Consequently, the smaller reduction in the numerator relative to denominator leads to a higher Tobin's Q in the face of deteriorating firm performance. Hence, under the condition of underinvestment a higher Tobin's Q may not reflect higher firm performance. Exploring how such a condition can be accounted for in a measure of firm performance would enhance the robustness of the estimated results in the literature thus far. 
Afkhami, Locke and Reddy (2013) report that, to date, NZ's managerial (insider) ownership is $12 \%$ and block (outsider) ownership is about $49 \%$. Although, NZ publicly listed firms had begun to track back to the moderate range of outside block ownership (OUTBLOWN), the issue of ineffective monitoring remained. Unless, the overall effectiveness in the ability and/or willingness of outside block holders to monitoring managers improves, pressuring management to deliver on performance, firm performance would remain weak. The evidence from the split share structure reform in China provides a good exemplar of how incentivising greater monitoring on the part of outside block holders (including block and institutional investors), can significantly improve firm performance. The Chinese reform provided a natural experiment of how, by converting shares owned by the controlling shareholders from nontradable shares to tradable shares, removes market friction and induces better monitoring on the part of outside block holders giving managers more incentives to improve firm performance (see Chen et al., 2014). Considerations of such an example is important because it illustrates for NZ how it is possible with a change in policy to induces a better set of incentives and/or preferences by shareholders to be more active and engage much more in their firm activities as effective monitors, which in effect incentivises managers to deliver on performance.

On the other hand, for small businesses, MBIE (2014) cited more than 100 government initiatives to support small businesses, including actions in the Business Growth Agenda and Result 9 work programme. These were to help businesses access to the key ingredients they need to grow and succeed. Yet our small-medium sized businesses are still struggling to grow into larger firms. Further exploration in these areas to assess the viability and effectiveness of these mechanisms and/or policies would be profitable for future research and one where intervention may be beneficial.

\section{New Zealand's Low Firm Performance and Productivity}

A stylized fact is that high performing or high-growth firms are rare in New Zealand (NZ). When firm performance matters to growth, the rarity of high-performing firms in NZ means growth, let alone high-growth, would also be an uncommon occurrence. In fact, highgrowth firms only make up a small proportion of the business population in NZ. Provisional figures from Statistics New Zealand's Integrated Data Infrastructure capturing the distribution of growth (measured in sales revenues) across the NZ economy in 2011 show that the population of 
firms in NZ has a skewed growth distribution (MBIE, 2013). They illustrate that in 2011 the median firm actually experienced negative growth and suggested that such relationship has held since at least 2001. Consistent with these results, Hull and Arnold (2008) also found that from 2000 to 2005 only a tiny percentage of NZ firms experienced an increase in turnover and that the majority actually experienced a reduction (as cited in MBIE, 2013). Above all, MBIE's (2013, p. $3,8)$ report cited recently unpublished research on business productivity growth showing that NZ has "a long tail of very low performers that may be able to survive because of weak competitive forces". More than that, in the previous section this paper showed they might be also able to persist because of lack of pressure on management to increase performance.

The reality is good firm performance is a necessary condition for commercial survival. Profitability and good firm governance leading to high firm performance and value to shareholders do make a difference to a given economy's ability to attract international capital. Hence, poor firm performance, due to poor exposure to pressure and competition in the domestic market would impede NZ's ability to attract international capital. Such inability is not such a problem if extra capital is not required. However, if firms come to the equity market for capital, equity market under-development would drive up the costs of capital as firms compete for the limited available capital in the thin equity market (Treasury, 2008b; Afkhami et al., 2013). In fact, one of the difficulties facing NZ's most productive and successful firms is access to, and attracting, investor capital (Healy, 2001; Castalia Strategic Advisors, 2003; Hall \& Scobie, 2005; Capital Market Taskforce, 2009; New Zealand Herald, 2014a). NZ's relative difficulty in shoring up its capital position and access to funds for investment and innovation would help explain NZ's weak international connections and low level and rate of innovation.

Furthermore, the reality of dominant shareholders and dominant firms sheltering management from pressure and competition in the domestic market not only impedes firm performance by ways of entrenchment, it also inhibits performance by impeding the development of managerial competencies. The lack of effective management disciplines to correct weaknesses in their business model or to look for new and better ways to doing business greatly hinders the development of managerial competencies. This is the sort of development needed for successful growth and international competition and expansion. This helps explain NZ's relatively low Management Practice Score (MPS) highlighted in Section 4. The rest of this section discuss how NZ's relative low firm performance, due to NZ's relatively lower managerial quality and managerial effectiveness (explained in Section 4 and 5), could account 
for NZ's weak international connections, low innovation and low managerial quality. The three main determinants (symptoms) of poor productivity performance identified by the New Zealand Productivity Commission's (2014a) report to have accounted for the 27 percentage points productivity gap between NZ and the average of 20 OECD countries.

\subsection{Low Firm Performance and Weak International Connections}

The New Zealand Productivity Commission (2014a) showed that over half of New Zealand's (NZ's) productivity gap relative to the OECD average could be explained by weaknesses in NZ's international connections. The lack of accessibility to large markets and limited participation in global value chains (where the transfer of advanced technologies now often occurs) facing NZ firms reflect NZ's firms' lack of activism in the international market. This paper argues that this is largely a consequence of firm under-performance. Evidence shows that better performing firms tend to enter international markets and that internationally active firms are larger, more productive, and pay higher wages than other firms in the same industry that are active only in their home market and vice versa (Wagner, 2014).

Evidently, the performance of NZ's large firms is poor by international comparison and $\mathrm{NZ}$ also has a shortage of large firms that can be found in a number of other OECD countries (Treasury, 2008b). Simmons (2004) showed, as measured by returns on assets or value added, large firms have been performing poorly in New Zealand (as cited in Treasury, 2008b). Though NZ has a similar proportion of people employed in large firm (250+), the number of large firms in NZ is less than the OECD average. NZ's economy is made up predominately of SmallMedium Enterprises (MBIE, 2013). Statistics New Zealand defined Small-Medium Enterprises (SMEs) as firms that comprises of less than 100 employees (Corner, 2001, p. 52; MBIE, 2013). On productivity grounds, Fallow (2013) points to a Productivity Commission research report which found labour productivity in 10 of 16 NZ's industries measured to be less than half of Australian levels. NZ sectors also compare unfavorably with the UK on Multifactor Productivity (MFP) performance (Treasury, 2008b, p. 10). Section 2 also highlights NZ's productivity underperformance relative to our OECD counterparts.

Wages in NZ are also relatively lower than most advanced OECD countries. This has been highlighted repeatedly both in the media (headlines like "New Zealanders get low wages" Rosenberg, 2011; and "David Clark: The PM's cleaner deserves more pay" - New Zealand 
Herald, 2012a) and in academic studies (Healy, 2003; Department of Labour, 2006 ${ }^{57}$; OECD, 2007 $7^{58}$; also see ANNEX 2 for CEO and Average Male and Female Income Comparison). In sum, firms in NZ are generally smaller, less productive, and pay lower wages (characteristics of poor firm performance - see Wagner, 2014) than other firms in the same industry of the average OECD countries. One should note that larger firms in NZ are also poor performers (see Box 2 on page 99) and hence it is not simply a matter of firm size. That is, firm size may be a necessary but not sufficient condition (by itself suffice) to explain improved performance.

Better Performing Firms ENGAGE in international activities. Wagner (2014) cited many empirical studies, written since the early 1990s, showing a positive association between firm performance and international market engagement. He suggested that because of the additional costs of participating in the foreign market, higher performing firms tend to self-select into international activities (i.e. exports, imports and offshoring ${ }^{59}$ ). For export activity, the additional costs include transportation, distribution, marketing, hiring of personnel with the skills to manage foreign networks and production costs of modifying current domestic products for foreign consumption. For importing, costs are largely associated with fixed costs involved in the search process for foreign suppliers, inspection of goods, negotiation, contract formation, and so on. For offshoring, the costs to the local economy may involve the issues associated with domestic jobs lost (particularly those of low-skilled) when production is relocated to countries where labour is cheaper.

The costs associated with these international activities exist as an entry barrier that less successful firms cannot overcome (Wagner, 2012). Findings have generally been in favour of the self-selection hypothesis, which says firms that eventually became exporters (internationally active) tended to be more productive than firms that never ventured outside the domestic market. Furthermore, only those highly productive firms import intermediate goods. While offshoring need not generate negative impact on domestic employment if some tasks (low skilled) performed by a certain type of labour can be more easily done offshore increasing the profitability of these firms leading to such firms' expansion. The increase in labour demand by these firms will in part fall on local workers who perform tasks (more skilled) that cannot easily

\footnotetext{
${ }^{57}$ Provide an in-depth discussion of the minimum wage and comparisons between New Zealand wages and other OECD countries is found in a Department of Labour report, Minimum wage review 2006, from paragraph 43 onwards.

${ }^{58} \mathrm{New}$ Zealand's low wage environment is also examined in an OECD report comparing different countries, Minimum Wages, Minimum Labour Costs and the Tax Treatment of Low-Wage Employment.

${ }^{59}$ Offshoring is the relocation of activities previously performed by a domestic firm to a firm in foreign country.
} 
be moved abroad. Hence, at the firm level, offshoring can generate positive impacts if the competitiveness of such firms increases through productivity increases. At the macro level, increases in the international division of labour and specialisation in products in which the home country has a comparative advantage would also foster growth. In most cases production that is relocated is no longer profitable in the home country and the employees would lose their jobs when firms shutdown whether or not they moved elsewhere. Nonetheless, the message is clear: high performing firms can expand and prosper abroad, while low performing firms cannot (Wagner, 2014).

Moreover, one of the major causes of Small-Medium Enterprises (SMEs) failure in NZ as well as overseas is under-capitalisation of the company (Cameron \& Massey, 1999, as cited in Corner, 2001). In other words, SMEs fail because they do not have an adequate amount of finance to cover the revenue shortfalls typical of start-ups or in the expansion phase of the business. Beyond their personal paid-in capital, the preference of SME owners in NZ is to secure additional finance through bank loans. Previous research shows that bankers rely heavily on the financial performance of a firm to make a loan decision (Berry et al., 1993; Reeve and van Peursem, 1998 as cited in Corner, 2001). Also consistent with this paper's narrative, firm performance (specifically profitability) are used not only to judge the financial 'health' of the company, but also to judge the competence of the company's management. Hence, poor firms' performance, due to an ownership structure that fails to induce sufficient pressure on managers to increase performance, by exacerbating the agency costs associated with managerial entrenchment, inhibits the ability of such firms to access capital needed during the period of expansion. Consequently, poor firm performance by increasing the costs of borrowing and by making it even more difficult for such firms to attract further capital to finance expansion would exacerbate the scale problems of NZ's SMEs.

New Zealand lack of pressure and competitive forces hurt global focus. The NZ domestic market size and its legacy of past statutory monopolies already mean a number of firms in many of its industries benefited from monopolistic or oligopolistic rents (Healy, 2003). The combined effect of high firm ownership concentration and deepening corporate consolidation that took place in the post 1970s further reduced firms' exposure to competitive forces. The lack of management exposure to significant competition in the domestic market also ill-equipped firms with the necessary business strategy to successfully competes in the international market. Exposure of management to sufficient domestic market competition is vital to successful growth 
and international expansion, especially when scale is a constraint. These essential conditions are lacking in the NZ economy. The scale constraint (of SMEs) need not be detrimental if one recognises, as per Watts (2008), that the challenge is one of both opportunity and strategy in overcoming such a constraint. In the last decade, Finland ${ }^{60}$ demonstrated this point (Jones, 2008). However, when scale is a constraint and the ability and incentives of firms to recognise, develop and implement strategies to overcome such a constraint is also problematic problems with international growth and expansion would result. These include the intent and ability of firms to launch themselves into international markets and their ability to maintain sustainable growth following an expansion. Both have proven to be problematic for NZ.

Grant Thornton's (2012) International Business Report shows that NZ sits second from the bottom in the number of companies that currently have international operations (only 9\%), well behind that of Australia's 16\%. While this figure does highlight NZ's geographic isolation, it also highlights NZ's lack of international activism and the nation continued reliance on traditional markets. In fact, of those NZ firms surveyed in this report only $9 \%$ were planning overseas growth, and of this $9 \%$, expansion plans are largely orientated toward traditional markets like Western Europe, United States, Canada and Australia. In contrast, the report revealed that $57 \%$ of those business leaders considering international expansion are looking at the five biggest emerging economies - China, India, Russia, Brazil and Mexico. Their report concluded that the barrier to NZ firms' international expansion is largely to do with the firms' intent to expand overseas, rather than the issue around red tape that is holding NZ firms back. Red tape is less of an issue for NZ because NZ firms tend to deal in the more traditional markets, instead of the frontier markets in which overseas firms are trying to open up.

Wang and O'Grady's (2013) overview of NZ firms based on their analysis of the Business Operation Survey 2011 data also reveal that about 20\% of firms surveyed were not interested in generating overseas income. The reason is being not productive enough to export or it is too risky for the firm to do so. NZ's long tail of very low performing firms has made international expansion very costly and highly risky, which in turn hurts NZ international expansion. Why? Because poor performing firms have to borrow at a higher premium and the lack of knowledge due to the lack of managerial exposure to pressure and competitive forces also increase the possibility of failure. This would explain why the history of NZ firms expanding into Australia

\footnotetext{
${ }^{60}$ See Gabrielsson et al. (2004) on the influence of financing strategies and the commensurate finance management capabilities on the globalization of Finnish Born International and Born Global SMEs.
} 
and other geographical markets has generally not been a success story (Healy, 2003, p. 121; See Box 1 on page 98, for Recent Evidence) and why to date "NZ companies fail to focus on global expansion" (Grant Thornton, 2012; see Box 2 on page 99, for The Story).

\subsection{Low Firm Performance and Low Innovation}

Consistent with the New Zealand Productivity Commission's (2014a) report this paper argues that most of the rest of the gap could be due to under-investment in "knowledge-based capital”, namely Research and Development (R\&D). R\&D undertaken by both the public and the private business sector in New Zealand (NZ) is reported to be among the lowest in the OECD. The low R\&D investment may to some extent be due to the absence or small share of $R \& D$ intensity demanded from NZ's key traditional agricultural industries. However such a structural bias does not completely account for the low ranking to the extent experienced in NZ. NZ ranked $18^{\text {th }}$ of the 19 advanced OECD countries sampled (New Zealand Productivity Commission, 2014c, p. 13). Furthermore, there is evidence that successful firms in Scandinavian traditional sectors do invest heavily in R\&D (Edquist, 2011). The same can also be said for Canada (see Natural Resources Canada, 2014). Hence, the real problem should be about the issue of firm performance.

Recall the argument in previous sections, that the performance of a business is strongly influenced by managerial decisions and that the quality of managerial decisions depends on both the ability of managers and on the incentives that they have to make these decisions (managerial effectiveness). Given that unresolved conflict is a conspicuous feature of organisations, as highlighted by Cyert and March (1963), profit maximisation is not the only form of behaviour. Hence, under a structure of ownership which fosters managerial entrenchment incentivising rent seeking at the cost of firm value, R\&D investment which is deemed as value enhancing may not take place and those non-value maximising may be over-invested for reasons of controlling agents (managers) pay, power and prestige. Consequently, the effects of R\&D on controlling agents' position means that they might under-invest (over-invest) in R\&D projects regardless of their potential positive (negative) impact on firm value.

The association between firm value and $R \& D$ investment suggests that causality may run the other way, whereby poor firm performance leads to low R\&D investment. Empirical research on the effect of ownership structure on firm performance in Table 7 (and elsewhere, Beyer et al., 
2011) shows that the association between ownership structure and firm performance is nonlinear. Ceteris paribus, implying the association between ownership structure and R\&D investment may also be non-linear, assuming the property of transitive relation holds. That is, if element A (ownership structure) is related to element B (firm value/performance), and B is in turn related to an element $C(R \& D$ investment), then $A$ is also related to $C$. This means that when concentrated ownership in NZ negatively affects firm value/performance, R\&D investment would also be negatively affected, leading to lower innovation.

The negative effect on R\&D investment would impede NZ's capacity for 'frontier innovation' and affect the ability of NZ firms to absorb new technologies developed elsewhere 'technology catch-up' (Griffith et al., 2004). This impedes the extent to which the NZ economy is exposed to external technologies on the one hand and the efficiency with which it absorbs them on the other hand. This would explain NZ's relative low level of technological change (low innovation) and low efficiency change (lagging behind), and thus low productivity change evidenced in Figure 6. More recently, the New Zealand Productivity Commission's (2014a) empirical estimates indicate that the large gap between NZ's R\&D intensity vis-à-vis the average of 20 OECD countries would explain between 3 to 11 percentage points of the 27 percentage points productivity gap between NZ and the average of 20 OECD countries. The report also shows that NZ's weak international connections and low investment in innovation (as measured by R\&D intensity) together could explain between 17 to 22 percentage points of the 27 percentage points productivity gap vis-à-vis the average of $20 \mathrm{OECD}$ countries, and that the rest of the gap can be accounted for by NZ's relative lower managerial quality.

Better performing firms ARE innovative. An $\operatorname{INSEAD}^{61}$ (2013) report reveals that better performing firms are those that continuously invest in learning how to use technology as well as in operating and innovating more effectively and efficiently. Their research results show that on average, firms that have strong business enablers ${ }^{62}$ and are high investors in technology have significantly greater chance of being high performers, and vice versa. To date, across the board, the fast growing and high achieving sector is Information Communication Technology (ICT). The OECD (2002, p. 81) defines "the ICT sector as a combination of manufacturing and services industries that capture, transmit and display data and information electronically". Within this sector, IT services in particular are generating significant innovation, attracting investment from

\footnotetext{
${ }^{61}$ INSEAD is a graduate business school with campuses in Europe, Asia and the Middle East.

${ }^{62}$ Two key business enablers are sufficient access to technology-focused talent and management-focused talent.
} 
established firms and start-ups and creating wealth and high-skilled employment opportunities. In NZ, the number of firms in computer system design has grown rapidly with more than 3300 such firms started in the last twelve years (Project Management Institute, 2014). ICT, much more than our traditional industries, strongly engage in R\&D investment. Exports of computer and information services have experienced a dramatic increase, by $85 \%$ since 2006 , with incomes in computer system design twice the NZ average and are growing faster than the average (New Zealand Sectors Report, 2013). This sector has traditionally received less attention than that of our primary and manufacturing sectors despite the sector's potential growth. With ICT growing significantly and its deep and extensive linkages with the rest of the economy (see Table 3), increased focus in this sector will prove essential for future growth and productivity.

New Zealand Lack of pressure and competitive forces hurt innovation. High performing/highgrowth firms, which add dynamic and competitive pressure within the economy, make up only a small proportion of NZ's business population. Their numbers and proportion also appear to be declining over time (see Figure $5^{63}$ and Figure 9 in MBIE, 2013, p. 13 and p. 29) ${ }^{64}$. According to the Business Growth Agenda (2012), the following facts imply that not enough innovative highgrowth firms: (i) are being created in NZ; and (ii) are staying located here; and (iii) are growing to the point where they generate significant economic benefits as well as stimulate innovation in other businesses (as cited in MBIE, 2013, p. 3). The lack of pressure on managers to increase performance unintentionally generated by NZ's highly concentrated firm ownership structure in addition to the lack of competitive forces in the NZ economy crucially contributes to these problems. Firstly, this is because the lack of pressure on managerial performance which negatively affect firm performance, act as a barrier to internationalisation faced by small firms. NZ's small domestic market means that internationalisation is an important way in which small firms can grow into medium or large firms either by growing extremely fast in a short period or by maintaining steady growth over a number of years. Secondly, Castellacci's (2009) econometric analysis of $\mathrm{CDM}$ mode ${ }^{65}$ using rich firm-level panel dataset based on the three

\footnotetext{
${ }^{63}$ Showed 'Percentage of high-growth businesses in the total population of New Zealand enterprises by sales, employment and value added. Where high-growth is defined as all enterprises with a minimum of $\$ 50,000$ in sales at the beginning of a 3-year period that record average annualised growth (in employment or turnover or added value) greater than $20 \%$ per annum over the 3 -year period. Sales and value added are derived from IR10 data (adjusted to exclude GST).

${ }^{64}$ Figures are in real dollars based on 2009 dollars.

${ }^{65} \mathrm{CDM}$ model studies the effect of competition on four interrelated stages of the innovative chain: the choice of whether or not to engage in innovative activities; the amount of resources it decides to invest in R\&D; the effects of these R\&D investments on innovative output; and the impacts of innovation output on the productivity of the enterprise.
} 
recent waves of the Innovation Survey for Norway ${ }^{66}$ found that the impact of innovative efforts on firm performance (technological output and productivity) is stronger in competitive sectors than in oligopolistic industries. This result supports the 'escape-competition effect' ${ }^{67}$ proposition, which postulates that competition may also spur innovation. This is because competition may increase the incremental profits that firms obtain by investing in R\&D activities (see also Aghion et al., 1997; 2005; 2009). The escape-competition effect asserts that the relationship between the degree of market competition and innovation maybe positive, and even more so in neck-to-neck industries where competition between rival firms is fierce.

In contrast, the lack of pressure and competitive forces in NZ's key traditional industries and the existence of dominant firm dominating the industry tend to discourage innovation because these firms' monopolistic position tend to encourage them to "become fat and happy and fall asleep" (Boyes, 2012). Consequently, under such a circumstance innovation need not occur. This explains why NZ dairy giants lack a track record of innovation and product development in difficult value-added dairy categories, such as Infant Formula. See Box 3 on page 100, Lack of Competition and Low Innovation: Example from Infant Formula.

\footnotetext{
${ }^{66}$ CIS3 (period: 1998-2000; $\mathrm{N}=3899$ ), CIS4 (period: 2002-2004; $\mathrm{N}=4655$ ) and CIS5 (period: 2004-2006; $\mathrm{N}=6443$ )

${ }^{67}$ Contrary to the traditional 'Schumpeterian effect' that postulates the negative association between the degree of competition in an industry and the R\&D intensity of firms; Castellacci (2009) finds such effect to be a mechanism that relates to the ex-ante incentives to innovate to be found in the early stages of the innovation process. While the 'escape-competition effect' is one of ex-post effects of innovation, i.e. the incremental profits that a firm effectively achieves, given its prior decision to invest in R\&D and to join the innovation race - occurred at later stages of the innovation chain. Consequently, though the probability that a firm engages in innovation and the amount of resources it decides to invest are higher in oligopolistic sector than in competitive industries, the impact of innovations efforts on firm performance (technological output and productivity), however, is stronger in competitive sectors than in oligopolistic industries.
} 


\section{Box 1. Recent Evidences}

"Traditionally, New Zealand businesses have performed poorly when it comes to international expansion. The 2013 Grant Thornton International Business Report placed New Zealand second from the bottom in a global ranking of countries, when it comes to the percentage of organisations that have expanded overseas."

(Stuff, 2013)

"In many traditional sectors, New Zealand has failed to forward integrate along the value chain, example from the meat industry shows despite sending meat to the UK for over 120 years, we own no major in-market processors... New Zealand still significantly makes the ingredients, which are sold to food manufacturers, who add-value by turning them into processed foods".

(Coriolis, 2010b, p. 18-19).

"Many New Zealand franchises find it hard to *generate enough cash flow locally to fund overseas expansion...you can't just go and be an international franchisor; you've got to invest hundreds of thousands. Money not the only factor that affects a company's ability to franchise internationally...successful export strategy requires ... *key senior management executive focus exclusively on international growth ... sadly too many approach the international scene with no more resource than that used for domestic expansion. ... Third non-negotiable is * sufficient domestic market strength to enable it to expand successfully overseas. The measure of readiness for international expansion is not solely the output or size of the franchise operation in its home country - it's more the infrastructural development and operational capability within the group".

(Franchise New Zealand, 2011).

"Two factors about New Zealand ... make the job of capital markets more difficult in New Zealand than overseas. Firstly, the high proportion of small firms may cause difficulties for the capital market. Capital markets all over the world do not finance many small firms due to the fixed costs and risk involved. Small firms traditionally rely on owner or angel capital. Secondly, the small domestic market may lead to a lack of specialized expertise in the New Zealand venture capital market rather than lack of capital per se. This may be a contributing factor behind firms turning to foreign purchasers in the same industry for expertise and networks".

(Treasury, 2002) 


\section{Box 2. The Story}

One of the biggest issues facing New Zealand (NZ) investors is the inability of the country's business leaders to create long-term growth firms. Many of our listed firms have achieved strong short-term growth but have failed to grow over the longer term. A survey of the largest NZX listed firms between 1984 and 2004 shows how poorly NZ's largest firms have performed. In this 20-year period 10 companies were ranked in the top three in terms of market value: Fletcher Challenge, Brierley Investments, NZ Forest Products, Chase Corporation, New Zealand Insurance, Carter Holt Harvey, Telecom, Lion Nathan, Fletcher Energy and Contact Energy. But only Contact Energy and Telecom remain listed on the NZX. Fletcher Challenge was split into separately listed energy, forestry, paper and building divisions. Brierley Investments now called GuocoLeisure and NZ Forest Products was taken over by Carter Holt Harvey (later acquired by Graeme Hart). New Zealand Insurance is now owned by Australia's IAG, Chorus was split from Telecom, Lion Nathan was acquired by Japanese interests and Fletcher Energy was sold to Shell.

Ironically Fletcher Building, which was originally the smallest of the four Fletcher Challenge divisions, is the only one to remain under New Zealand ownership. By contrast Australian companies have had a far greater survival rate. Between 1984 to the end of 1994, seven of the top 10 ASX firms remain listed, but only four of the top 10 NZX firms do so. Surveys show that NZX firms, as far as wealth creation is concerned, also perform poorly. Between 1984 to the end of 1994 their total value has fallen by $\$ 6.8$ billion (22\% drop). While ASX firms increased their total market value by A $\$ 437.7$ billion (over $400 \%$ ). There has also been substantial attrition - and minimum wealth creation - among the fourth and fifth ranked NZX companies by market capitalisation between 1984 and 2004. The latter group comprised ANZ Banking Group (NZ), Wattie Industries, Bank of New Zealand, DB Breweries, Goodman Fielder, Air New Zealand, Fletcher Paper, Fletcher Forests, The Warehouse, Fisher \& Paykel Healthcare and SkyCity. The first four were acquired by overseas interests, as were the two Fletcher companies. Goodman Fielder migrated to Australia, Air New Zealand was in the top five before it was bailed out by the Crown in the early 2000s and The Warehouse was highly rated before its failed expansion into Australia. A large number of our companies have stalled badly when they moved offshore (Pumkin Patch, Rakon, The Warehouse and Tourism Holdings).

Many of our firms simply don't have overseas expertise. Consequently, they are poorly prepared and under resourced when they go offshore. The problems may be because extremely successful firms like Sir Ron, in the past, have been so successful with its asset stripping, downsizing and cost cutting strategies in the 1970s and 1980s, a large number of business people since then have copied this approach rather than going for growth through higher value-added innovation. Why? Saunders et al. (2011) suggested that as a consequence of NZ's history of guaranteed access to and its distance from markets, NZ's agricultural sector has yet to develop a good appreciation of the importance of value of marketing credence attributes. This inhibits NZ's ability to charge a premium for its products. Faced with increasing international competition cutting costs is a quick fix in order to achieve margin. However, cost cutting in the long run is not the answer to prosperity, big profits lie elsewhere - in the ability of firms to charge a premium on their products and services. Additionally, NZ has been far too quick to sell companies with good growth prospects (Bank of New Zealand, Fletcher Energy and Trust Bank). Furthermore, the NZX is heavily populated with regulated utilities and companies with limited growth opportunities. In light of these factors, no wonder domestic investors are extremely enthusiastic about Xero and a number of other technology businesses with high growth aspiration.

(Treasury, 2008b; New Zealand Herald, 2014b; Saunders et al., 2011) 


\section{Box 3. Lack of Competition and Low Innovation: Example from Infant Formula}

Infant formula, a difficult value-added dairy category, where New Zealand's dairy firms (Fonterra, Meadow Fresh, Westland, OpenCountry, Synlait and TATUA) lack a track record of innovation and products development relative to the other international dairy firms (Nestle, DANONE, Mead Johnson and Abbott) (Coriolis, 2014, p. 15). Over the last decade, some of the major innovations in infant formula that have come out of international dairy firms are formula with: probiotics ${ }^{68}$ for supporting the immune system, DHA/ARA (Docosahexaenoic acid) ${ }^{69}$ for brain and eye development, hypoallergenic amino-acid based ${ }^{70}$ for children with cow's milk allergies, Lactobacillus rhamnosus $\mathrm{GG}^{71}$ probiotic for strengthening intestinal barrier, Acidified Liquid $^{72}$ for premature babies, OptiGRO ${ }^{\mathrm{TM}}$ (blend of DHA, Lutein and Vitamin E) ${ }^{73}$ for brain and eye development, eye health and to support cells development, and so on (Abbott, 2014; Coriolis, 2014, p. 15; Nestle, 2014; DANONE, 2014).

In comparison, goat milk based formula is the only clearly identifiable innovation in infant formula to have come out of NZ and be in the market. Further NZ waited 15 years following the invention of Ultra-high-temperature (UHT) milk to launch a product. NZ dairy firms, in this sense, clearly lag far behind (Coriolis, 2014). Such a lag reflects the reality of how incumbents who have not had disruptive competition will be slow to innovate. For a dominant unassailable incumbent, the pressure to deliver better and more innovative products is simply not there. Consequently, this means more often than not products and countries would go through lifecycles as follows. At the early life stage (i.e. during the pastoral boom), the opportunity to gain value from participating in co-operative agribusinesses is greatest when product innovation is strong and supply is fragmented. But this is only to be followed by rapid consolidation and domination by a few large firms to which a gradual decline in rates of innovation (and subsequently performance) becomes the single biggest risk to these mature businesses. Coriolis's (2014) report comparing R\&D expenditure of the top 4 global infant formula firms to the top 6 NZ dairy firms in 2012 illustrates NZ dairy firms' low R\&D expenditure, both as a percent of global sales and in total value (see Coriolis, 2014, p. 14).

The message here is that when there is not much domestic market competition, and combined with NZ's history of guaranteed access to and its distance from markets, a good appreciation of the importance and value of marketing credence attributes can be an unusual occurrence (Saunders et al., 2011). Consequently, when faced with increasing international competitions a cost cutting strategy to achieve short-term margin becomes much easier (though not the answer to long term growth) than difficult high value-added innovation.

\footnotetext{
${ }^{68}$ Probiotics are friendly microorganisms/bacteria that provide health benefits by improving the balance of flora in the digestive system.

${ }^{69}$ DHA is an omega-3 fatty acid, which is a primary structural component of the human brain, cerebral cortex and retina.

${ }^{70}$ Hypoallergenic use amino acids (the building blocks of proteins) as their protein source, and are best for infants who have severe protein allergies and are suffering colic.

${ }^{71}$ Lactobacillus rhamnosus GG is a bacteria that exist naturally in the body, primarily in the intestine, which helps to maintain a balance of 'good bacteria' needed to prevent the growth of harmful bacteria in the stomach and intestines.

${ }^{72}$ Acidified Liquid is an ultra-concentrated liquid human milk fortifier with extra nutrients.

${ }^{73}$ OptiGRO $^{\mathrm{TM}}$ is an exclusive blend of nutrients in Similac infant formula to support eyes and brain developments.
} 


\subsection{Low Firm Performance and Low Managerial Competency}

Lack of managerial exposure to pressure and competitive force not only directly affects firm performance by way of entrenchment, resulting in weak international connections and low innovation, it also inhibits the development of managerial competencies essential to international competition and expansion. The latter phenomenon would explain NZ's relative low Management Practice Score (MPS), a proxy for managerial competency, evidenced in Section 4. The New Zealand Productivity Commission (2014a) also named NZ's low managerial practices as the third main determinant responsible for NZ's lower productivity gains from new technology, attributable for the rest of gap. Following weak international connections and low innovation, low managerial quality is capable of explaining the rest of the gap, even more so when such an effect is cumulative.

My analysis in section 4 concludes that closing the overall managerial practices gap judged by MPS between NZ and the top 5 OECD countries would increase productivity by $5 \%$. This together with NZ's weak international connections and low innovation associated with poor firm performance, largely as a consequence of inappropriate incentives unintentionally generated by a certain ownership structure that encourage managerial entrenchment at the cost of firm performance, can potentially explain 'The New Zealand Productivity Puzzle ${ }^{\text {,74. }}$

\section{Conclusions}

Overall, by analytically piecing together key results and findings (from available data, literature, and empirical studies), this paper goes further than merely highlighting the determinants (symptoms) of poor productivity performance in New Zealand. The paper essentially brings to light the potential mechanism behind New Zealand's relative poor productivity performance. In so doing, this paper answers the question 'why' these key determinants (symptoms) of poor productivity performance occur.

Beginning with an overview of New Zealand's productivity performance in Section 2, this paper highlights that given New Zealand's policy settings, New Zealand's GDP per capita should be about 20\% above the OECD average, however it is actually $20 \%$ below (Barnes et al., 2013; Fallow, 2013; New Zealand Productivity Commission, 2014a). The extent to which New

\footnotetext{
${ }^{74}$ See Diagrammatic Summary in ANNEX 3.
} 
Zealand's actual productivity growth rates have undershot its predicted rates based on policy setting, has generated spirited debates among experts seeking to provide an answer to this ageold paradox. Solving 'The New Zealand Productivity Puzzle' is not a straightforward proposition. Previous studies in this area show that the main determinants behind New Zealand's relatively poor productivity performance are weak international connections, low innovation and low managerial quality (New Zealand Productivity Commission, 2014a). No doubt, New Zealand is lacking in these aspects and of course we need to do more in these areas to improve our productivity performance. However, by puzzling together a richer picture of New Zealand's productivity situation, this paper shows these key determinants are merely symptoms arising from perhaps a much deeper cause. In so doing, the paper answers the question, 'why' decisions makers in New Zealand make decisions that lead to poor performance in these areas.

By investigating New Zealand's relative productivity under-performance as an issue of corporate/firm governance in section 3, this paper reveals that firm governance issues in New Zealand is not one of poor corporate governance in a conventional manner. Rather one related to (A) low managerial competency and (B) low managerial effectiveness. The analyses carried out on these issues in section 4 and 5 verified this proposition, showing firm performance would be lower when managers lack the ability and the incentives to manage the assets and resources they have under their stewardship to create value for shareholders. The analysis in Section 4, based on Management Practice Score (MPS) from the World Management Survey (2010) on managerial practices across a number of OECD countries showed closing the MPS gap between New Zealand and the top 5 OECD countries could increase productivity by $5 \%$. However, when the quality of managerial decisions depends not only on the ability of managers, but also on the incentives that managers have to make decisions such that profits can be maximised by maximising productivity, managerial effectiveness therefore also matters. In Section 5, the paper explored the available theoretical and empirical research that examined the cross sectional relationship between insider ownership (INOWN) and firm performance (Tobin's Q) to draw inferences for managerial effectiveness.

The results from the analysis in Section 5 suggested that high ownership concentration (i.e. high outside block ownership) at the level experienced in New Zealand had been detrimental to firm performance. This result supports Healy (2001) argument that outside block ownership (OUTBLOWN including institutional and block holdings) in New Zealand does not support the proposition that institutional and block ownership reinforces the positive effect of insider 
ownership on firm value added when New Zealand institutional and block holders play a very passive role in monitoring firms. Such a result in New Zealand is contrary to those found in the United States (the subject of previous studies). This may be because foreign financial institutions and corporations account for the majority of investments in New Zealand equity market, but the geographical separation of those foreign institutional investors from their invested firms and the dispersion in institutional ownership makes monitoring and collaboration among outside block holders difficult. Therefore, the costs of monitoring may outweigh the benefits they hoped to gain. This would explain the ineffective institutional monitoring and the lack of shareholders activism observed in New Zealand compared to the United States.

This paper also highlights how the absence of effective monitoring leaves managers relatively free from checks on their control reduces managerial effectiveness, and thus lowers firm performance. Without the monitoring pressure to enforce and incentivise managers to deliver on performance managers would be relatively ineffective, and thus firm performance would be lower. This paper shows irrespective of the nature of the firms (publicly listed or small businesses) or managerial stakes in the firm, the absence from checks on managerial control would exacerbate the agency costs associated with managerial entrenchment. In theory, Leibenstein (1966) and Altman (1993) have made these points. The problem of ineffective monitoring, therefore, potentially explains the "long tail of very low performers" firms in New Zealand (MBIE, 2013, p. 3, 8).

The reality is firm performance matters to growth and a necessary condition for commercial survival, which matters a lot to a given economy's ability to attract international capital and the development of a more vibrant equity market. Hence, poor firm performance arises largely as a consequence of managerial incentives to be entrenched generated by a highly concentrated ownership structure that fails to induce effective monitoring. This impedes an economy's ability to attract international capital and the development of its equity market. If firms come to the equity market for capital, equity market under-development would drive up the costs of capital as firms compete for the limited available capital in the thin equity market (Treasury, 2008b; Afkhami, Locke \& Reddy, 2013).

Consequently, New Zealand firms' relative difficulty to shore up their capital position and access to funds for investment and innovation would explain the economy's weak international connections and low innovation. Moreover, the effect of high ownership 
concentration in an already weak competitive domestic market further enhances the scope in which management can be sheltered from pressure to deliver on performance. The lack of effective management discipline to correct weaknesses in their business model or to search for new and better ways to doing business, further impedes the development of managerial quality in New Zealand. In Section 6, this paper explains how together weak international connections and low innovation and poor managerial quality associated with lower firm performance potentially explains 'New Zealand's 27 percentage points productivity gap vis-à-vis the average of the 20 OECD countries' (New Zealand Productivity Commission, 2014a).

Finally, this paper shows that New Zealand productivity under-performance is not paradoxical, but is rather largely a function of firm governance. The sort of causal variables uncovered here is neither one of corporate governance in the conventional manner or an issue of managerial competency alone. Rather what is key is that as consequence of inappropriate incentives unintentionally generated by an inappropriate ownership structure, managers are left relatively free from checks on their behaviour. This provides managers greater scope to exercise their preferences and entrenching such behaviours even if these are not in the best interest of their firms. This leads to relatively low overall firm performance, much of this related to a relatively low productivity performance.

This paper is a first attempt to explain the New Zealand productivity under-performance being largely a function of firm governance. The paper was only able to provide a thorough survey of the problem. Hence, going forward an in-depth analysis of 'New Zealand's Productivity Under-Performance as a Function of Firm Governance' is necessary; in order to give greater weight to the argument and to verify the extent to which New Zealand country's performance could be improved if firms are being as productive as they positively could be under a better set of incentives and/or preferences by management and workers. Such an in-depth analysis not only entails a comprehensive investigation of the existing literature, recent available firm-level data and findings on the association between ownership structure and firm performance, it also involves the considerations of what other factors may be in play. Factor(s) that could positively propel (i.e. the initiatives toward high value-added productions - Saunders et al., 2011) or negatively impede (i.e. the barriers to internationalisation, Shaw \& Darroch, 2004) New Zealand improved firm's capability in relation to a better set of incentives and/or preferences by management and workers to translate into improved country's performance. 


\section{References}

Abbott. (2014). Innovative products trusted by generations of moms. Retrieved from http://www.abbott.com/our-products/similac.html

Acemoglu, D., Johnson, S. \& Robinson, J.A. (2004). Institutions as the fundamental cause of long-run growth. Retrieved from http://www.nber.org/papers/w10481.pdf.

Acemoglu, D., Johnson, S. \& Robinson, J.A. (2005). The Rise of Europe: Atlantic Trade, Institutional Change and Economic Growth. American Economic Review, 95(3): 546-579.

Afkhami, R. S., Locke, S. \& Reddy, K. (2013). The global financial crisis and the role of ownership structure on cost of capital. Asian Journal of Finance and Accounting, 5(1): 396-418.

Agarwal, R., Green, R., Brown, P.J., Tan, H. \& Randhawa, K. (2013). Determinants of quality management practices: An empirical study of New Zealand manufacturing firms. International Journal of Production Economics, 142(1): 130-145.

Aghion, P., Bloom, N., Blundell, R., Griffith, R. \& Howitt, P. (2005). Competition and Innovation: An Inverted-U Relationship. Quarterly Journal of Economics, 120: 701-728.

Aghion, P., Blundell, R., Griffith, R. \& Howitt, P. (2009). The Effects of Entry on Incumbent Innovation and Productivity. Review of Economics and Statistics, 91: 20-32.

Aghion, P., Harris, C. \& Vickers, J. (1997). Competition and Growth with Step-by-Step Innovation: An Example. European Economic Review, Papers and Proceedings, 771-782.

Altman, M. (1993). Human agency as a determinant of material welfare. The Journal of SocioEconomics, 22(3): 199-218.

Altman, M. (2003). Staple Theory and Export-Led Growth: Constructing Differential Growth. Australian Economic History Review, 43: 230-255.

Altman, M. (2004). The Nobel Prize in Behavioural and Experimental Economics: a Contextual and Critical Appraisal of the Contributions of Daniel Kahneman and Vernon Smith, Review of Political Economy, 16: 3-41.

Altman, M. (2005). Staples and Staple Theory. History of World Trade since 1450, John J. McCusker, ed., New York: Gale/Macmillan.

Altman, M. (2013). Economic Growth and the High Wage Economy: Choices, Constraints and Opportunities in the market economy. Routledge: London, New York (2012).

Andjelkovic, A., Boyle, G., \& McNoe, W. (2002). Public disclosure of executive compensation: Do shareholders need to know? Pacific-Basin Finance Journal, 10(1): 97-117.

Barnes, S., Bouis, R., Briard, P., Dougherty, S. \& Eris, M. (2013). “The GDP Impact of Reform: A Simple Simulation Framework", OECD Economics Department Working Papers, No. 834, OECD Publishing. http://dx.doi.org/10.1787/5kgk9qinhkmt-en

Baumol, W.J. (2002). The Free-Market Innovation Machine: Analyzing the Growth Miracle of Capitalism. Princeton, N.J.: Princeton University Press.

Becker, B.E. \& Huselid, M.A. (1998). High Performance Work Systems and Firm Performance: A Synthesis of Research and Managerial Implications. Retrieved from http://mgt.buffalo.edu/departments/ohr/becker/publications/High\%20Performance\%20Work\%20 Systems.pdf.

Bergeijk, P.A.G. \& Lazzaroni, S. (2013). Macroeconomics of Natural Disasters: Meta-Analysis and Policy Options. Retrieved from http://www.hsph.harvard.edu/wpcontent/uploads/sites/1273/2013/09/Bergeijk-Lazzaroni-Sept.-2013.pdf.

Berle, A.A.Jr \& Means, G.C. (1932). The Modern Corporation and Private Property. New York: Macmillan.

Beyer, M., Czarnitzki, D., \& Kraft, K. (2011). Managerial Ownership, Entrenchment and Innovation. Retrieved from http://ftp.zew.de/pub/zew-docs/dp/dp11026.pdf.

Bhabra, G.S. (2007). Insider ownership and firm value in New Zealand. Journal of Multinational Financial Management, 17(2): 142-154. 
Bloom, N. \& van Reenen, J. (2007). Measuring and Explaining Management Practices Across Firms and Countries. The Quarterly Journal of Economics, CXXII (4): 1351-1408.

Bloom, N. \& van Reenen, J. (2010). Why do management practices differ across firms and countries? Journal of Economic Perspectives, 24(1): 203-224.

Bloom, N. Sadun, R. \& van Reenen, J. (2012a). Does Management Really Work? Harvard Business Review, 90 (11): 77-80, 82,148.

Bloom, N., Genakos, C., Sadun, R. \& van Reenen, J. (2012b). Management Practices Across Firms and Countries. Retrieved from http://www.oecd.org/std/productivity-stats/7\%20Session\%203a\%20\%20Genakos\%20-\%20AMP.pdf.

Borkin, P. (2009). Past, Present and Future Developments in New Zealand's Terms of Trade. Retrieved from http://www.treasury.govt.nz/publications/research-policy/wp/2006/06-09/twp06-09.pdf

Boulhol, H. \& de Serres, A. (2010). Have developed countries escaped the curse of distance?, Journal of Economic Geography, Oxford University Press, 10(1): 113-139.

Bourne, M., Kennerley, M. \& Franco-Santos, M. (2005). Managing Through Measures: A Study of Impact on Performance. Journal of Manufacturing Technology Management, 16(4): 373-395.

Boussemart, J.P., Briec, W., Poutineau, J.C. \& Kerstens, K. (2001). Luenberger and Malmquist Productivity Indices: Theoretical Comparisons and Empirical Illustration. Retrieved from http://www.researchgate.net/profile/Jean_Christophe_Poutineau/publication/5086750_Luenberge r_and_Malmquist_Productivity_Indices_Theoretical_Comparisons_and_Empirical_Illustration/li nks/548841bb0cf $268 \mathrm{~d} 28 \mathrm{f08c7a7}$.pdf

Boyes, W. (2012). Managerial Economics: Markets and the Firm. Canada: South-Western, Cengage Learning.

Brickley, J. A., Lease, R. C. \& Smith, C. W. (1988). Ownership Structure and Voting on Antitakeover Amendments. Journal of Financial Economics, 20: 267-291.

Brou, D. \& Ruta, M. (2006). Special Interests and the Gains from Political Integration, Economics and Politics, 18(2): 191-218.

Brune, N. \& Sweeny, A. (2012). Canada's Digital History III. Canada - The New Nation. Kindle Edition: Northern Blue Publishing.

Bundă, N.R., Moise-Ţiţei, A. \& Jaliu, D.D. (2012). A New Institutional Approach of the Complex Correlation Between Economic Freedom and Economic Growth. European Journal of Science and Theology, 8(1): 75-84.

Capital Market Development Taskforce. (2009). Do Capital Markets Matter For New Zealand? Retrieved from http://www.med.govt.nz/business/economic-development/pdf-docs-library/cmd-taskforceresearch/why-capital-markets-matter.pdf.

Carter, N.M., Gartner, W.B., Shaver, K.G., \& Gatewood, E.J. (2003). The career reasons of nascent entrepreneurs, Journal of Business Venturing, 18:13-39.

Castalia Strategic Advisors. (2003). The Impact of New Zealand's Capital Market Constraints on Productivity and Growth. Retrieved from http://www.productivity.govt.nz/sites/default/files/symposium-ppt-03_b_gerritsen_capital.pdf.

Castellacci, F. (2009). How does competition affect the relationship between innovation and productivity? Estimation of a CDM model for Norway. Retrieved from http://mpra.ub.unimuenchen.de/27591/1/MPRA_paper_27591.pdf

Caves, D. W., Christensen, L. R. \& Diewert, W. E. (1982). The Economic Theory of Index Numbers and the Measurement of Input, Output, and Productivity. Econometrica, 50(6): 1393-1414.

Central Intelligence Agency. (2012). The World Factbook. Retrieved from https://www.cia.gov/library/publications/the-world-factbook/fields/2012.html

CentrePiece. (2005). Management Practices: impact on company performance. Retrieved from http://cep.lse.ac.uk/pubs/download/CP177.pdf.

Chartered Secretaries New Zealand Inc. (2011). Governance, Sustainability and the New Zealand Small to Medium Enterprise Sector. Retrieved from http://csnz.org/Folder?Action=View\%20File\&Folder_id=68\&File=Governance\%20sustainability $\% 20$ and $\% 20$ the $\% 20 \mathrm{NZ} \% 20$ SME $\% 20$ sector.pdf 
Chen, H., Hexter, J.L. \& Hu, M.Y. (1993). Management Ownership and Corporate Value. Managerial and Decision Economics, 14: 335-346.

Chen, S. Lin, B., Lu, R. \& Zhang, T. (2014). Controlling shareholders incentive and executive pay-forperformance sensitivity: Evidence from the split shares structure reform in China. Retrieved from https://editorialexpress.com/cgibin/conference/download.cgi?db_name=CICF2014\&paper_id=239.

Cho, M. (1998). Ownership structure, investment, and the corporate value: an empirical analysis. Journal of Financial Economics, 47: 103-121.

Chung, Y.H., Färe, R. \& Grosskopf, S. (1997). Productivity and undesirable outputs: a directional distance function approach. Journal of Environmental Management, 51(3): 229-240.

Claus, I., Lattimore, R., Le, T. \& Stroombergen, A. (2011). 50 Years of Structural Change: An Analysis of Input-Output Tables since 1953. Retrieved from http://nzae.org.nz/wpcontent/uploads/2011/08/50_Years_of_Structural_Change_An_Analysis_of_InputOutput_Tables_since_1953.pdf

Co-operative Business New Zealand. (2014). What we mean by a cooperative. Retrieved from http://2yzguv1p7v4qcijx032i7nkd.wpengine.netdna-cdn.com/wp-content/uploads/2014/07/Whatwe-mean-by-a-cooperative-16.1-ALT.pdf

Conway, P. \& Meehan, L (2013). Productivity by the Numbers the NZ Experience. Retrieved from http://www.productivity.govt.nz/sites/default/files/Commission\%20Research\%20Paper\%20$\% 20$ Conway $\% 20$ Meehan $\% 20$ Productivity $\% 20$ by $\% 20$ the $\% 20$ Numbers $\% 20$ $\% 20$ Productivity\%20by\%20the\%20numbers\%20(final).pdf.

Coriolis. (2010a). Fonterra \& the New Zealand dairy industry: options going forward, a discussion document. Retrieved from

http://www.coriolisresearch.com/pdfs/coriolis_firm_dairy_03_0909_fonterra_options_going_for ward_101a.pdf.

Coriolis. (2010b). Moving to the centre: the future of the New Zealand food industry. Retrieved from https://www.med.govt.nz/sectors-industries/food-beverage/pdf-docs-library/coriolis-report-pdf

Coriolis. (2012). Driving growth in the Processed Foods sector. Retrieved from https://www.med.govt.nz/sectors-industries/food-beverage/pdf-docs-library/informationproject/processed-foods-dec-2012-v1.pdf

Coriolis. (2014). Policy Implications of Global Value Chain Research: Part of the NZPECC dairy value chain project. Retrieved from http://nzpecc.org.nz/media/f3c9cc3577fc96acffff80c9ffffd502.pdf.

Cornelius, P. (2005). Good corporate practices in poor governance systems: Some evidence from the global competitiveness report. Corporate Governance, 5(3): 12-23.

Corner, P. (2001). Improving the Performance of New Zealand SMEs: Measures for Success. University of Auckland Business Review, 3(2): 51-66.

Crocombe, G. T., Enright, M. J. \& Porter, M. E. (1991). Upgrading New Zealand's Competitive Advantage. New Zealand: Oxford University Press.

Cyert, R. \& March, J. G. (1963). A Behavioral Theory of the Firm. Engelwood Cliffs, NJ: Prentice-Hall.

D’Alessandro, S. \& Drago, F. (2003). Natural Limits to Economic Development: Endogenous Growth or Panacea?*. Retrieved from

http://www.druid.dk/conferences/winter2003/Paper/DAlessandro_Drago.pdf

Dana, L.P. \& Schoeman, J. (2010). An Entrepreneurial Innovation: Mega Cooperatives. Asia Pacific Journal of Innovation and Entrepreneurship, 4(1): 67-87.

DANONE. (2014). Early life nutrition. Retrieved from http://www.danone.com/en/for-all/our-4-businesslines/early-life-nutrition/

Davison, G. \& Brodie, M. (2005). Closer Settlement in Queensland: The Rise and Decline of the Agrarian Dream, 1860s-1960s. Retrieved from http://books.publishing.monash.edu/apps/bookworm/view/Struggle+Country\%3A+The+Rural+Id eal+in+Twentieth+Century+Australia/140/xhtml/chapter06.html

Dawson, J. W. (2007). The Empirical Institutions-Growth Literature: Is Something Amiss at the Top? Econ Journal Watch, 4(2): 184-196. 
Demsetz, H. (1983). The Structure of Ownership and the Theory of the Firm. Journal of Law and Economics, 26(2): 375-390.

Demsetz, H. \& Villalonga, B. (2001). Ownership Structure and Corporate Performance. Retrieved from http://papers.ssrn.com/sol3/papers.cfm?abstract_id=266101.

Department of Labour. (2006). Minimum Wage Review 2006. Retrieved from http://www.dol.govt.nz/er/pay/backgroundpapers/officials-report-2006.pdf

Dybvig, P.H. \& Warachka, M. (2010). Tobin's Q Does Not Measure Performance: Theory, Empirics, and Alternative Measures*. Retrieved from http://www4.fe.uc.pt/jasa/m_i_2010_2011/tobinsqdoesnotmeasureperformance.pdf.

Edquist, H.O. (2011). Intangible Investment and the Swedish Manufacturing and Service Sector Paradox. Retrieved from http://papers.ssrn.com/sol3/papers.cfm?abstract_id=2234941

Eicher, T. \& Röhn, O. (2007). Institutional Determinants of Economic Performance in OECD Countries - An Institutions Climate Index. Retrieved from http://faculty.washington.edu/te/papers/ERdice.pdf.

Evans, L. (2012). Cooperatives in New Zealand: the particular case of dairy. Retrieved from http://www.iscr.org.nz/f780,21379/3_September_Seminar_Slides_FINAL_Lewis_Evans.pdf

Evans, L. \& Meade, R. (2005). The Role and Significance of Cooperatives in New Zealand Agriculture: A Comparative Institutional Analysis. Retrieved from http://maxa.maf.govt.nz/mafnet/ruralnz/profitability-and-economics/trends/iscr-report-dec2005/pdf-version/full-report.pdf.

Evans, L. \& Richardson, M. (1998). Trade Reform in New Zealand: Unilateralism at Work. Retrieved from http://www.iscr.org.nz/f261,5183/trade_reform_in_nz_011198.pdf.

Fallow, B. (2013). Brian Fallow: Productivity gaps a real mystery. Retrieved from http://www.nzherald.co.nz/business/news/article.cfm?c_id=3\&objectid=11130048.

Fama, E. F., \& Jensen, M. C. (1983). Separation of ownership and control. Journal of Law and Economics, 26: 301-325.

Färe, R., Grosskopf, S., Norris, M. \& Zhang, Z. (1994). Productivity Growth, Technical Progress, and Efficiency Change in Industrialized Countries. The American Economic Review, 84(1): 66-83.

Fauzi, F. \& Locke, S. (2012). Board Structure, ownership structure and firm performance: a study of New Zealand listed-firm. Asian Academy of Management Journal of Accounting and Finance, 8(2): 43-67.

Fitzsimons, P. (1997). Takeovers and efficiency in the context of concentrated shareholdings: The case of New Zealand. Company Securities Law Journal, 15:4-21.

Foss, N.J. \& Klein, P.G. (2005). The Theory of the Firm and Its Critics A Stocktaking and Assessment. Retrieved from https://mises.org/journals/scholar/foss-klein2.pdf.

Fox, M., Walker, G. \& Pekmezovic, A. (2012). Corporate Governance Research on New Zealand Listed Companies. Retrieved from http://www.library .auckland.ac.nz/subjectguides/bus/infosources/nzcompany.htm

Fox, M.A. (1996). Corporate Control and Financial Performance of New Zealand Companies. Retrieved from https://researcharchive.lincoln.ac.nz/bitstream/10182/972/3/cd_dp_14.pdf.

Frances, J. (2004). Institutions, Firms and Economic Growth. Retrieved from http://www.treasury.govt.nz/publications/research-policy/wp/2004/04-19/twp04-19.pdf.

Franchise New Zealand. (2011). Overseas Experience Kiwis Going Global. Retrieved from http://www.franchise.co.nz/article/1207-overseas-experience-br-kiwis-going-global.

Friedman, M. \& Friedman, R. (1980). Free to Choose: A Personal Statement. London: Secker \& Warburg.

Gabrielsson, M., Sasi, V. \& Darling, J. (2004). Finance strategies of rapidly-growing Finnish SMEs: Born Internationals and Born Globals. European Business Review, 16(6): 590-604.

Garelli, S. (2001). Competitiveness of Nations: The Fundamentals. Retrieved from http://www.imd.org/uupload/www01/documents/wcc/content/fundamentals.pdf. 
Gatewood, E.J., Shaver, K.G., \& Gartner, W.B. (1995). A longitudinal study of cognitive factors influencing start-up behaviors and success at venture creation, Journal of Business Venturing, 10: 371-391.

Gedajlovic, E. R. \& Shapiro, D. M. (1998). Management and Ownership Effects: Evidence from the Five Countries. Strategic Management Journal, 19: 533-553.

Glaeser, E. L., Resseger, M., \& Tobio, K. (2009). Inequality in cities. Journal of Regional Science, 49(4): 617-646.

Glaeser, E.L., Porta, R., Lopez-de-silanes, F. \& Shleifer, A. (2004). Do Institutions Cause Growth? Journal of Economic Growth, 9: 271-303.

Gomez-Mejia, L.R., Haynes, K. T., Nunez-Nickel, M., Jacobson, K. J. L. \& Moyano-Fuentes, J. (2007). Socioemotional Wealth and Business Risks in Family-controlled Firms: Evidence from Spanish Olive Oil Mills. Retrieved from

http://e-archivo.uc3m.es/bitstream/handle/10016/7304/socioemotional_nunez_ASQ_2007.pdf? sequence $=1$.

Gompers, P., Ishii, J. \& Metrick, A. (2003). Corporate Governance and Equity Prices, The Quarterly Journal of Economics, 118(1), 107-155.

Grant Thornton. (2012). 2012 press releases: NZ companies fail to focus on global expansion. Retrieved from http://www.grantthornton.co.nz/Press/2012-press-releases/nz-companies-fail-to-focus-onglobal-expansion.html.

Grant Thornton. (2014). The productivity problem: what we can do about it. Retrieved from http://www.grantthornton.co.nz/Assets/documents/pubSeminars/GTNZ-productivity-240914.pdf

Greasley, D. \& Oxley, L. (2009). The Pastoral Boom, the Rural Land Market, and Long Swings in New Zealand Economic Growth 1873-1939. The Economic History Review, 62(2): 324-349.

Green, R., Agarwal, R., Brown, P., Tan, H. \& Randhawa, K. (2011). Management Matters in New Zealand: How Does Manufacturing Measure Up? Retrieved from http://www.med.govt.nz/aboutus/publications/publications-by-topic/occasional-papers/2011-occasional-papers/11-03-pdäää.

Griffith, R., Redding, S. \& van Reenen, J. (2004). Mapping the Two Faces of R\&D: Productivity Growth in a Panel of OECD Industries. The Review of Economics and Statistics, 86(4): 883-895.

Gugler, K., Mueller, D.C. \& Yurtoglu, B.B. (2003). Separating the Wealth and Entrenchment Effects of Insider Ownership on Investment Performance. Retrieved from http://www.wu.ac.at/sm/iqv/mitarbeiter/gugler/gmy2.pdf.

Gupta, P.K. (2012). Mergers and Acquisitions (M\&A): The Strategic Concepts for the Nuptials of Corporate Sector. Innovative Journal of Business and Management, 1(4): 60-68.

Gwartney, J. \& Lawson, R. (2007). Economic Freedom of the World: 2007 Annual Report. Vancouver: Fraser Institute.

Hall, J. \& Scobie, G. (2005). Capital Shallowness: A Problem for New Zealand? Retrieved from http:/www.treasury.govt.nz/publications/research-policy/wp/2005/05-05/twp05-05.pdf.

Hall, R. E. \& Jones, C. I. (1999). Why do some countries produce so much more output? Quarterly Journal of Economics, 114(1): 83-116.

Haque, F., Arun, T. \& Kirkpatrick, C. (2012). Corporate Governance and Capital Markets: A Conceptual Framework. Retrieved from http://virtusinterpress.org/additional_files/journ_coc/full-text-papersopen-access/Paper012.pdf.

Hawke, G. R. (1985). The Making of New Zealand: An Economic History. Cambridge: Cambridge University Press.

Hayek, F.A. (1954). Capitalism and the Historians. Chicago: The University of Chicago Press.

Healy, J. (2001). New Zealand Capital Markets. Paper presented at the Ministry of Economic Development, Wellington.

Healy, J. (2003). Corporate Governance and Wealth Creation in New Zealand. Palmerston North, New Zealand: Dunmore Press Ltd.

Helpman, E. \& Krugman, P. (1985). Market Structure and International Trade. Cambridge MA: MIT Press. 
Hennigan, M. (2014). German living standard highest in Europe: Irish, Italians, Spanish among Eurozone's poorest. Retrieved from http://www.finfacts.ie/irishfinancenews/article_1027831.shtml.

Hermalin, B.E. \& Weisback, M.S. (1991). The Effects of Board Composition and Direct Incentives on Firm Performance. Financial Management, 20(4): 101-112.

Hirschman, A. (1958). The Strategy of Economic Development. New Haven, Yale University.

Holderness, C.G. \& Sheehan, D.P. (1988). The Role of Majority Shareholders in Publicly Held Corporations. Journal of Financial Economics, 20: 317-46.

Holderness, C.G., Kroszner, R.S. \& Sheehan, D.P. (1999). Were the Good Old Days That Good? Change in Managerial Stock Ownership since the Great Depression. The Journal of Finance, LIV (2): 435-468.

Holweg, M. (2007). The genealogy of lean production. Journal of Operations Management, 25: 420-437.

Hossain, M., Pervost, A., Rao, R.P. (2001). Corporate governance in New Zealand: the effect of the 1993 Companies Act on the relation between board composition and firm performance. Pacific-Basin Financial Journal, 9: 119-145.

Hu, Y. \& Izumida, S. (2008). The Relationship between Ownership and Performance: A Review of Theory and Evidence. International Business Research, 1(4): 72-81.

Huang, X. (2009). Efficiency Institutions and China's Great Transformation: A research Framework. Retrieved from http://www.victoria.ac.nz/chinaresearchcentre/Research/China\%20Papers/11.XiaomingHuangChina's\%20Great\%20Transformation.pd

Hubbard, G. \& Palia, D. (1995). Benefits of control, managerial ownership, and the stock returns of acquiring firms. RAND Journal of Economics, 26(4): 782-792.

Hurst, E. G. \& Pugsley, B. W. (2010). Non Pecuniary Benefits of Small Business Ownership. Retrieved from http://economics.stanford.edu/files/Hurstpp2_10_25.pdf.

Hussey, D.D. \& Philpott, B. P. (1969). Productivity \& Income of New Zealand Agriculture 1921-1967. Retrieved from http://researcharchive.lincoln.ac.nz/dspace/handle/10182/1228.

Hylton, P. \& Lucas, C. (1966). Land Settlement. Retrieved from http://www.teara.govt.nz/en/1966/28001/print.

INSEAD. (2013). Building Competitiveness and Business Performance with ICT. Retrieved from http://ec.europa.eu/information_society/newsroom/cf/dae/document.cfm?doc_id=1665.

International Co-operative Alliance. (2014). Co-operative identity, values \& principles. Retrieved from $\mathrm{http} / /$ ica.coop/en/whats-co-op/co-operative-identity-values-principles

International Monetary Fund. (2013). World Economic Outlook Database. Retrieved from https://www.imf.org/external/pubs/ft/weo/2013/01/weodata/index.aspx.

Jensen, M. C. \& Meckling, W. H. (1976). Theory of the Firm: Managerial Behavior, Agency Costs and Ownership Structure. Retrieved from http://www.sfu.ca/ wainwrig/Econ400/jensenmeckling.pdf.

Jensen, M.C. \& Ruback, R.S. (1983). The Market for Corporate Control: The Scientific Evidence. Journal of Financial Economics, 11: 5-50.

Jiang, H. (2008). Ownership Concentration and CEO Compensation Pay-for-Performance Sensitivity in New Zealand. Retrieved from http://www.pbfeam2008.bus.qut.edu.au/papers/documents/HaiyanJiang_Final.pdf.

Jiang, H., Habib, A. \& Smallman, C. (2009). The effect of ownership concentration on CEO compensation-firm performance relationship in New Zealand. Pacific Accounting Review, 21(2): 104-131.

Jones, G. (2008). Management the Aotearoa New Zealand Context. Milton Qld: John Wiley \& Sons Australia, Ltd.

Kendall, R. \& Ng, T. (2013). Reserve Bank of New Zealand Analytical Note series: Estimated Taylor Rules updated for the post-crisis period. Retrieved from http://www.rbnz.govt.nz/research_and_publications/analytical_notes/2013/an2013_04.pdf 
Kim, W. \& Lyn, O. (1988). Excess market value, market power, and inside ownership structure. Review of Industrial Organization, 3 (4): 1-25.

Kleinschmidt, M. (2007). Venture Capital, Corporate Governance and Firm Value. Wiesbaden, Germany: Deutscher UniversitSts-Verlag.

Kolvereid, L. (1996). Prediction of employment status choice intentions. Entrepreneurship Theory and Practice, 21: 47-57.

Kumar, V. (2014). Cloud computing as a strategy for NZ Business. Retrieved from http://www.nbr.co.nz/article/cloud-computing-business-strategy-ck-136714.

Kuratko, D. F., Hornsby, J. S. \& Naffziger, D. W. (1997). An examination of owner's goals in sustaining entrepreneurship, Journal of Small Business Management, 35(1): 24-33.

Lau, A. \& Vos, E. (2004). Relation between CEO compensation, firm size and firm performance. New Zealand Journal of Applied Business Research, 3(1): 51-64.

Leach, D. \& Leahy, J. (1991). Ownership Structure, Control Type Classifications and the Performance of Large British Companies. The Economic Journal, 101(409): 1418-1437.

Lee, S. \& Ryu, K. (2003). Management Ownership and Firm's Value: An Empirical Analysis Using Panel Data. Retrieved from http://www.iser.osaka-u.ac.jp/library/dp/2003/DP0593.pdf.

Leibenstein, H. (1966). Allocative Efficiency vs. "X-Efficiency". The American Economic Review, 56(3): 392-415.

Leibenstein, H. (1973). Notes on X-Efficiency and Technical Change. In Micro-Aspects of Development, edited by Eleizer B. Ayal, pp. 18-38. New York: Praeger.

Levine, R. \& Zervos, S. (1998). Stock Markets, Banks, and Economic Growth. The American Economic Review, 88 (3): 537-558.

Long, C. D. (1958). Appendix C: Labour Force, the Unemployment, and the Employed in Adult-Male Equivalents. Retrieved from http://www.nber.org/chapters/c2631.pdf.

Maher, M. \& Andersson, T. (1999). Corporate Governance: Effects on Firm Performance and Economic Growth. Retrieved from http://www.oecd.org/sti/ind/2090569.pdf.

Mak, A., Cheung, M.W., Fu E.H. \& Ho, R. C. (2010). Meta-analysis in medicine: an introduction. International Journal of Rheumatic Diseases, 13(2): 101-4.

Mason, G. (2013). Investigating New Zealand-Australia Productivity Differences at Industry Level. Retrieved from http://www.productivity.govt.nz/sites/default/files/NZPC-NZ-Australiaproductivity-working-paper-2013-02.pdf.

Mason, G. \& Osborne, M. (2007). Productivity, Capital-Intensity and Labour Quality at Sector Level in New Zealand and the UK. Retrieved from http://www.treasury.govt.nz/publications/researchpolicy/wp/2007/07-01.

Matarazzo, B. \& Nijkamp, P. (1997). Meta-analysis for comparative environmental case studies: methodological issues. International Journal of Social Economics, 24(7/8/9): 799-811.

MBIE. (2013). High-growth business in New Zealand. Retrieved from https://www.med.govt.nz/aboutus/publications/publications-by-topic/evaluation-of-government-programmes/defining-successhigh-growth-firms-in-new-zealand-789-kb-pdf.

MBIE. (2014). The Small Business Sector Report 2014. Retrieved from http://www.mbie.govt.nz/whatwe-do/business-growth-agenda/sectors-reports-series/pdf-document-library/the-small-businesssector-report-2014.pdf

McCann, P. (2009). Policy Watch: Economic geography, globalization and New Zealand's productivity paradox. New Zealand Economic Papers, 43(3): 279-314.

McConnell, J. J., \& Servaes, H. (1990). Additional evidence on equity ownership and corporate value. Journal of Financial Economics, 27: 595-612.

McConnell, J.J. \& Servaes, H. (1995). Equity ownership and the two faces of debt. Journal of Financial Economics, 39: 131-157.

McKinsey \& Company (2007). Management Practice \& Productivity: Why they matter. Retrieved from http://web.stanford.edu/ nbloom/ManagementReport.pdf. 
McKinsey \& Company. (1997). The Virtuous Cycle of Shareholder Value Creation. The McKinsey Quarterly, 2: 156-167.

McNulty, P.J. (1967). Allocative Efficiency vs. "X-Efficiency": Comment. The American Economic Review, 57(5): 1249-1252.

MED. (2011). Composition of the New Zealand Economy. Retrieved from http://www.med.govt.nz/aboutus/publications/publications-by-topic/economic-indicators/economic-development-indicators2011/2011-economic-development-indicators-ch3.pdf/at_download/file.

Mell, P. \& Grance, T. (2011). The NIST Definition of Cloud Computing. Retrieved from http://csrc.nist.gov/publications/nistpubs/800-145/SP800-145.pdf.

Morck, R., Schleifer. A., \& Vishny, R. (1988). Management Ownership and Market Valuation: An Empirical Analysis. Journal of Financial Economics, 20:293-315.

National Equal Opportunity Network (2007). New Zealand as a low wage economy. Retrieved from http://www.neon.org.nz/newsarchive/nzlwe/.

Natural Resources Canada. (2014). Innovation: Products and Processes. Retrieved from http://www.nrcan.gc.ca/forests/innovation/13329

Nestle. (2014). Infant formula. Retrieved from https://www.nestlebaby.com.au/products/infant-formula/

New Zealand Custom Service. (2014). Tariff and concessions. Retrieved from http://www.customs.govt.nz/incommercial/tariffandconcessions/Pages/default.aspx.

New Zealand Herald. (2008). Owen Hembry: Meat mega-merger hopes gain traction. Retrieved from http://www.nzherald.co.nz/business/news/article.cfm?c_id=3\&objectid=10522533

New Zealand Herald. (2012a). David Clark: The PM's cleaner deserves more pay. Retrieved from http://www.nzherald.co.nz/nz/news/article.cfm?c_id=1\&objectid=10831428.

New Zealand Herald. (2012b). Brian Gaynor: Foreign ownership shortchanging locals. Retrieved from http://www.nzherald.co.nz/business/news/article.cfm?c_id=3\&objectid=10854140.

New Zealand Herald. (2014a). Capital Markets: Graham Turley: Agribusiness for investors. Retrieved from http://www.nzherald.co.nz/business/news/article.cfm?c_id=3\&objectid=11250326.

New Zealand Herald. (2014b). Brian Gaynor: Business leaders failing long-term growth test. Retrieved from http://www.nzherald.co.nz/business/news/article.cfm?c_id=3\&objectid=11195066.

New Zealand Productivity Commission. (2013). Why New Zealand Industries Lag Behind Australia. Retrieved from http://www.productivity.govt.nz/news/why-new-zealand-industries-lag-behindaustralia.

New Zealand Productivity Commission. (2014a). An International Perspective on the New Zealand Productivity Paradox. Retrieved from http://www.productivity.govt.nz/sites/default/files/international-perspective-working-paper.pdf.

New Zealand Productivity Commission. (2014b). Boosting productivity in the services sector. Retrieved from http://www.productivity.govt.nz/inquiry-content/1624? stage $=4$.

New Zealand Productivity Commission. (2014c). New Zealand's productivity story - more questions than answers. Retrieved from http://www.oecd.org/sti/ind/Session\%203\%20$\% 20$ Paul\%20Conway.pdf.

New Zealand Sectors Report. (2013). Information and Communications Technology. Retrieved from http://www.mbie.govt.nz/pdf-library/what-we-do/business-growth-agenda/sectors-reportsseries/sector-report-information-communication-technology.pdf.

North, D.C. (1959). Agriculture in Regional Economic Growth. Journal of Farm Economics, 41: 943951.

North, D.C. (1990). Institutions, Institutional Change, and Economic Performance. Cambridge: Cambridge University Press.

North, D.C. \& Thomas, R.P. (1973). The Rise of the Western World: A New Economic History. Cambridge, U.K.: Cambridge University Press.

Nuen, S. \& Santerre, R.E. (1986). Dominant Stockownership and Profitability. Managerial and Decision Economics, 7: 207-210.

NZIER (2014). Productivity. Retrieved from http://nzier.org.nz/economics/productivity 
O'Connor, T. (2009). The structural failure of Irish economic development and employment policy. Retrieved from http://publish.ucc.ie/ijpp/2010/01/tomoconnor/03/en.

OECD. (2002). Annex 1. The OECD definition of the ICT sector. Retrieved from http://www.oecd.org/internet/ieconomy/2771153.pdf.

OECD. (2007). Directorate for Employment, Labour and Social Affairs: OECD Social Employment and Migration Working Papers. Retrieved from http://www.oecd.org/social/soc/37930738.pdf

OECD. (2008). Lifting productivity: lessons from the OECD. Retrieved from $\mathrm{http} / / /$ www.oecd.org/general/liftingproductivitylessonsfromtheoecd.htm.

OECD. (2012). Corporate Governance, Value Creation and Growth: The Bridge between Finance and Enterprise. Retrieved from http://www.oecd.org/dataoecd/57/36/50242938.pdf.

OECD. (2013). OECD Economic Surveys New Zealand. Retrieved from http://www.oecd.org/newzealand/new-zealand-2013.htm.

OECD. (2014a). Multifactor productivity. Retrieved from http://stats.oecd.org/Index.aspx?DatasetCode=PDYGTH.

OECD. (2014b). Dataset: Labour Productivity growth in the total economy. Retrieved from http://stats.oecd.org/Index.aspx?DatasetCode=LEVEL\#.

Oh, D. \& Heshmati, A. (2010). A Sequential Malmquist-Luenberger Productivity Index: Environmentally sensitive productivity growth considering the progressive nature of technology. Energy Economics, 32: 1345-1355.

Osenton, T. (2004). The Death of Demand: Finding Growth in a Saturated Global Economy. Upper Saddle River: Pearson Education Inc.

Park, D. (2014). Scoping Out Alliances And Joint Ventures. Retrieved from http://www.b2binternational.com/publications/alliances-joint-ventures/

Persson, L. (2005). The failing firm defense. The Journal of Industrial Economics, 53(2): 175-201.

Pfarrer, M.D. (2007). What is the Purpose of the Firm?: Shareholder and Stakeholder Theories. Retrieved from http://www.enterpriseethics.org/Portals/0/PDFs/good_business_chapter_07.pdf.

Pires, J. O. \& Garcia, F. (2012). Productivity of Nations: A Stochastic Frontier Approach to TFP Decomposition. Economics Research International, 2012: 1-19.

Pound, J. (1988). Proxy contests and the efficiency of shareholder oversight. Journal of Financial Economics, 20: 237-265.

Project Management Institute. (2014). Projects on the Map: New Zealand. Retrieved from http://www.pmi.org/Learning/pm-network/2014/projects-on-map-new-zealand.aspx

Rao, P. (2004). Efficiency and Productivity Measurement: Index Numbers. Power point: School of Economics. The University of Queensland, Australia. Retrieved from http://www.euklems.net/data/workshop/slides/Lecture\%202_Day_1_Index\%20Numbers.ppt

Reddell, M. (2013). The long-term level "misalignment" of the exchange rate: some perspectives on causes and consequences. Retrieved from

http://www.rbnz.govt.nz/research_and_publications/seminars_and_workshops/Mar2013/5200823 .pdf.

Reis, E. (2006). Managerial Incentives and Takeover Wealth Gains. Retrieved from http://scholarworks.gsu.edu/cgi/viewcontent.cgi?article=1007\&context=finance_diss

Rodrik, D., Subramanian, A. \& Trebbi, F. (2004). Institutions Rule: The Primacy of Institutions over Geography and Integration in Economic Development. Journal of Economic Growth, 9: 131-165.

Rohwer, A. (2011). Institutions Matter -Results of the Institutions Climate Index for OECD Countries. Retrieved from https://www.cesifogroup.de/portal/page/portal/AE9D67BA01125172E04400144FAFB1DA

Romer, P. M. (1990). Endogenous Technical Change, Part 2: The Problem of Development: A Conference of the Institute for the Study of Free Enterprise Systems. Journal of Political Economy, 98(5): 71-102.

Rosenberg, B. (2011). New Zealanders get low wages. Retrieved from http://www.stuff.co.nz/dominionpost/comment/5824465/New-Zealanders-get-low-wages. 
Rotherham, F. (2014). New Zealand productivity still lags. Retrieved from http://www.stuff.co.nz/business/better-business/9949697/New-Zealand-productivity-still-lags

Saunders, C. \& Dalziel, P. (2014). Economic Analysis for Policy. Retrieved from https://gen.org.nz/tikidownload_file.php?fileId $=527 \&$ display

Saunders, C., McDonald, H. \& Driver, T. (2011). Enhancing Value for New Zealand Farmers by Improving the Value Chain. Retrieved from http://www.motu.org.nz/publications/detail/enhancing_value_for_new_zealand_farmers_by_impr oving the value chain

Scoop. (2014). Low innovation and weak international connections. Retrieved from http://www.scoop.co.nz/stories/BU1404/S00497/low-innovation-and-weak-internationalconnections.htm

Shaw, V. \& Darroch, J. (2004). Barriers to Internationalisation: A Study of Entrepreneurial New Ventures in New Zealand. Journal of International Entrepreneurship, 2(4): 327-343.

Shestalova, V. (2003). Sequential Malmquist indices of productivity growth: an application to OECD industrial activities. Journal of Productivity Analysis, 19(2): 211-226.

Shleifer, A. \& Vishny, R.W. (1997). A Survey of Corporate Governance. Journal of Finance, 52(2): 73784.

Simon, H. (1955). A behavioral model of rational choice. The Quarterly Journal of Economics, 69(1): 99118.

Small, D. (2013). Corporatising NZ Agriculture the Growing Costs At Home and Abroad. Retrieved from http://www.converge.org.nz/watchdog/25/03.htm

Smith, A. (1937). An Inquiry into the Nature and Causes of the Wealth of Nations. Edwin Cannan, ed. Modern Library Edition. New York: Random House.

Smith, C. (2011). Conference summary: New Zealand's macroeconomic imbalances - causes and remedies. Retrieved from http://reservebank.govt.nz/research_and_publications/reserve_bank_bulletin/2011/2011sep74_3S mith.pdf.

Sousa, R. \& Voss, C. A. (2008) Contingency Research in Operations Management Practices. Journal of Operations Management, 26 (6): 697-713.

State Services Commission. (1998). New Zealand's State Sector Reform: A Decade of Change. Retrieved from http://www.ssc.govt.nz/decade-of-change.

Statistics New Zealand. (2013). Industry Productivity Statistics: 1978-2011. Retrieved from http://www.stats.govt.nz/browse_for_stats/economic_indicators/productivity/IndustryProductivity Statistics_HOTP78-11.aspx.

Statistics New Zealand. (2014a). Productivity Statistics: 1978-2013. Retrieved from http://www.stats.govt.nz/browse_for_stats/economic_indicators/productivity/ProductivityStatistic s_HOTP78-13.aspx

Statistics New Zealand. (2014b). Productivity. Retrieved from http://www.stats.govt.nz/browse_for_stats/economic_indicators/productivity.aspx

Stiglitz, J. (1985). Credit Markets and the Control of Capital. Retrieved from http://academiccommons.columbia.edu/download/fedora_content/download/ac:160112/CONTEN T/5164079.pdf.

Stuff. (2013). International expansion for New Zealand businesses. Retrieved from http://www.stuff.co.nz/business/better-business/new-zealand-post-betterbusiness/9486214/International-expansion-for-New-Zealand-businesses.

Stulz, R.M. (1988). Managerial control of voting rights: financing policies and the market for corporate control. Journal of Financial Economics, 20: 25-54.

Te Ara. (2012a). Economic History: Early pastoral economy. Retrieved from http://www.teara.govt.nz/en/economic-history/page-4.

Te Ara. (2012b). Story: National income and GDP. Retrieved from http://www.teara.govt.nz/en/graph/23587/gdp-per-capita-for-selected-oecd-countries. 
Teece, D.J. (1993). The Dynamics of Industrial Capitalism: Perspectives on Alfred Chandler's Scale and Scope*. Journal of Economic Literature, XXXI: 199-225.

The Global Innovation Index. (2014). Data Analysis: 2014 Country Rankings. Retrieved from https://www.globalinnovationindex.org/content.aspx?page=data-analysis

The World Bank Group. (2013). Worldwide Governance Indicators. Retrieved from info.worldbank.org/governance/wgi/index.aspx\#home.

The World Bank Group. (2014). Doing Business Measuring Business Regulations: Economy Rankings. Retrieved from http://www.doingbusiness.org/rankings

TheMoneyIllusion. (2010). Economic freedom and GDP per capita. Retrieved from http://www.themoneyillusion.com/?p=5575.

Thrall, R.M. (2000). Measures in DEA with an application to the Malmquist index. Journal of Productivity Analysis, 13: 125-137.

Tobin, J. (1969). A General Equilibirum Approach to Monetary Theory. Journal of Money, Credit, and Banking, 1(1): 15-29.

Tone, K. (2004). Malmquist Productivity Index: Efficiency Change Over Time. International Series in Operations Research \& Management Science, 71: 203-227.

Treasury. (2002). Growing Pains: New Zealand Qualitative Evidence on Hurdles to Exporting Growth. Retrieved from http://www.treasury.govt.nz/publications/research-policy/wp/2002/02-10/twp0210.pdf.

Treasury. (2008a). Investment, Productivity and the cost of capital: Understanding New Zealand's "Capital Shallowness". Retrieved from http://www.treasury.govt.nz/publications/researchpolicy/tprp/08-03.

Treasury. (2008b). Enterprise and Productivity: Harnessing Competitive Forces. Retrieved from http://www.treasury.govt.nz/publications/research-policy/tprp/08-04/tprp08-04.pdf.

University of Groningen. (2004). Groningen Growth and Development Centre: Maddison Historical Statistics. Retrieved from http://www.rug.nl/research/ggdc/databases.

Vroom, G. \& McCann, B. T. (2009). Ownership Structure, Profit Maximization, and Competitive Behavior. Retrieved from http://www.iese.edu/research/pdfs/di-0800-e.pdf.

Wagner, J. (2012). International trade and firm performance: A survey of empirical studies since 2006. Review of World Economics, 148:2 (2012): 235-267.

Wagner, J. (2014). Effect of international activity on firm performance. IZA World of Labour, 47: 1-10.

Wang, G. \& O'Grady, D. (2013). The International Engagement of New Zealand Firms. Retrieved from https://www.mbie.govt.nz/about-us/publications/occasional-papers/2013-occasional-papers/1301.pdf.

Watts, T. (2008). Strategies for New Zealand manufacturing small and medium sized enterprises going global. Unpubl. Masters Thesis, Massey University.

Wellalage, H. N. \& Locke, S. (2011). Agency costs, ownership structure and corporate governance mechanisms: A case study in New Zealand unlisted small companies. Journal of Business Systems, Governance and Ethics, 6 (3): 53-65.

Wellalage, H. N. \& Locke, S. (2012). An Empirical Investigation of Agency Costs and Ownership Structure in Unlisted Small Businesses. New Zealand Journal of Applied Business Research, 10(2): 37-48.

Williamson, O.E. (1988). Corporate Finance and Corporate Governance. The Journal of Finance, XLIII(3): 567-591.

Woodford, K. (2008). The Diversity of Co-operative Structures in New Zealand Agribusiness. Journal of Co-operative Studies, 41.1: 4-10.

World Economic Forum Geneva, Switzerland. (2006). The World Economic Forum Gender Gap Index 2006. Retrieved from http://www3.weforum.org/docs/WEF_GenderGap_Report_2006.pdf

World Economic Forum. (2011). The Global Competitiveness Report 2010-2011. Retrieved from http://www.weforum.org/reports/global-competitiveness-report-2010-2011-0. 
World Management Survey. (2010). Management Matters in New Zealand - How does manufacturing measure up? Retrieved from http://worldmanagementsurvey.org/wpcontent/images/2010/07/Report_Management-Matters-in-New-Zealand-How-doesmanufacturing-measure-up.pdf.

Wright, P., Ferris, S.P., Sarin, A. \& Awasthi, V. (1996). Impact of corporate insider, blockholder and institutional equity ownership on firm risk taking. Academy of Management Journal, 39(2):441463.

Wruck, K. (1989). Equity ownership concentration and firm value: Evidence from private equity financings. Journal of Financial Economics, 23: 3-28.

Xiaochuan, Z. (2004). Improve Corporate Governance and Develop Capital Market. Retrieved from $\mathrm{http} / / /$ www.bis.org/review/r050128d.pdf?frames $=0$.

Zheng, J. (2012). Knowledge Production Function and Malmquist Index Regression Equations as a Dynamic System. Retrieved from

http://www.economics.handels.gu.se/digitalAssets/1391/1391502_zheng-paper.pdf.

\section{ANNEX}

\section{OECD Member Countries}

On 14 December 1960, twenty countries signed the Convention to become members of the Organisation for Economic Co-operation and Development (OECD) and since then fourteen more countries have become members of the Organisation.

The current 'OECD Member Countries' (and the year in which they deposited their instruments of ratification) are: Australia (1971), Austria (1961), Belgium (1961), Canada (1961), Chile (2010), Czech Republic (1995), Denmark (1961), Estonia (2010), Finland (1969), France (1961), Germany (1961), Greece (1961), Hungary (1996), Iceland (1961), Ireland (1961), Israel (2010), Italy (1962), Japan (1964), Korea (1996), Luxembourg (1961), Mexico (1994), Netherlands (1961), New Zealand (1973), Norway (1961), Poland (1996), Portugal (1961), Slovak Republic (2000), Slovenia (2010), Spain (1961), Sweden (1961), Switzerland (1961), Turkey (1961), United Kingdom (1961) and United States (1961).

The 20 OECD Countries are: Australia, Austria, Belgium, Canada, Denmark, Finland, France, Ireland, Italy, Japan, Netherlands, New Zealand, Norway, Portugal, Spain, Sweden, Switzerland, United Kingdom and United States.

2. New Zealand's Firm Size, Productivity and Pay

Tower Perrins Worldwide Total Remuneration (2000)

\begin{tabular}{|c|c|c|c|c|c|}
\hline Country & Salary US\$000 & \multicolumn{3}{|c|}{ Breakdown of CEO Remuneration } \\
\hline & Level & Base (\%) & Bonus (\%) & $\begin{array}{c}\text { Long term } \\
\text { Incentive (\%) }\end{array}$ & Other (\%) \\
\hline NZ & 258 & $80 \%$ & $12 \%$ & - & $8 \%$ \\
\hline CAN & 752 & $43 \%$ & $16 \%$ & $36 \%$ & $5 \%$ \\
\hline AUS & 646 & $44 \%$ & $38 \%$ & $12 \%$ & $6 \%$ \\
\hline USA & 1404 & $35 \%$ & $16 \%$ & $43 \%$ & $6 \%$ \\
\hline UK & 720 & $44 \%$ & $15 \%$ & $17 \%$ & $24 \%$ \\
\hline
\end{tabular}

Source: Tower Perrins (2000) as cited in Healy (2003, p. 174). The table showed in 2000, relative to the sampled countries, NZ executives are badly paid on average (at US\$258,000), and also paid badly with about $80 \%$ of NZ executive's income is in the form of a fixed base with no long-term incentives and poor bonus component. 
'Badly paid' - NZ as a low wage economy makes attracting and retaining managerial talents in NZ difficult. The reality is NZ's firms must compete with other firms internationally to retain and attract the best management talent. The demand for good management talent far outstrips supply. Therefore top talent should (must) be paid internationally competitive market rates if it is to be retained. NZ's low pay culture is clearly a strong deterrent to attracting and retaining talents and as a consequence it acts as a self-imposed constraint on economic growth. Good managers can make a significant difference to a business and not only grow shareholder wealth but expand employment opportunities and further productivity.

'Paid badly' - Even if the market for executives is deemed efficient in the sense that the rate of pay offered for jobs ensures optimal supply of executive talent, this does not mean that compensation is efficient in the sense of getting optimal effort. In reality, effort is not fixed and executive contracts are inevitably incomplete. This bears no or little relation to the assumption of fixed effort and optimal contract assumed under the conventional economic theory. Consequently, there are opportunities for shirking. To this end, it is clear that a promise to pay a fixed wage for unobservable effort is counterproductive because there is no incentive to perform, let alone outperform. The disconnectedness between pay and performance, in this respect, explained why CEO compensation is insensitive to shareholder wealth creation as observed in Andjelkovic et al. (2002), but instead correlated with size of firms (see Healy, 2003 p. 173; Lau \& Vos, 2004).

NZ and other selected OECD countries Incomes Comparison (in Annual Income PPP, in USD)

\begin{tabular}{|c|c|c|}
\hline Country & Average Income Male & Average Income Female \\
\hline NZ & $\$ 26,960$ & $\$ 18,379$ \\
\hline AUS & $\$ 34,446$ & $\$ 24,827$ \\
\hline CAN & $\$ 37,572$ & $\$ 23,922$ \\
\hline US & $\$ 33,713$ & $\$ 20,790$ \\
\hline
\end{tabular}

Note: PPP denoted Purchasing Power Parity. Source: The World Economic Forum Gender Gap Index 2006. 


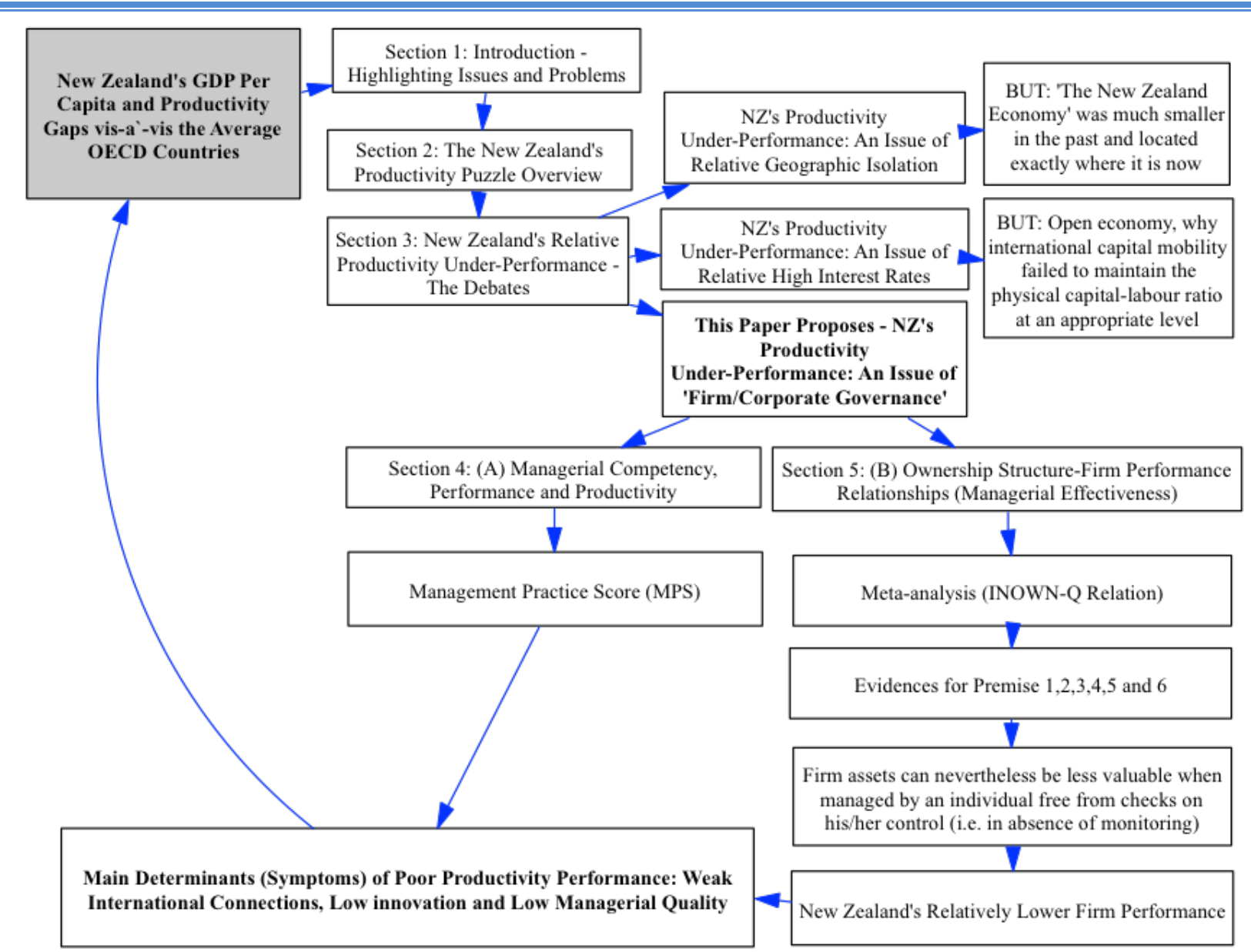

